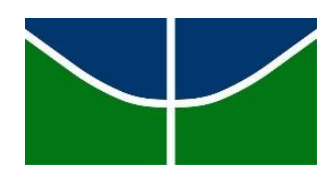

Faculdade de Economia, Administração e Contabilidade - FACE Programa de Pós-Graduação em Administração - PPGA Mestrado Profissional em Administração - MPA

\title{
AVALIAÇÃO NACIONAL DA ALFABETIZAÇÃO E PROVINHA BRASIL: PERCEPÇÃO DOS GESTORES E SUAS FUNÇÕES
}

\author{
PATRÍCIA DA SILVA ONÓRIO PEREIRA
}

Brasília - DF

2015 


\title{
AVALIAÇÃO NACIONAL DA ALFABETIZAÇÃO \\ E PROVINHA BRASIL: \\ PERCEPÇÃO DOS GESTORES E SUAS FUNÇÕES
}

\author{
Patrícia da Silva Onório Pereira
}

Dissertação submetida à Comissão Examinadora do Programa de Pós-Graduação em Administração - PPGA/FACE/UnB, como requisito parcial para a obtenção do título de Mestre Profissional em Administração.

Orientador: Professor Doutor João Mendes da Rocha Neto 


\title{
AVALIAÇÃO NACIONAL DA ALFABETIZAÇÃO E PROVINHA BRASIL: PERCEPÇÃO DOS GESTORES E SUAS FUNÇÕES
}

\begin{abstract}
Dissertação submetida à Comissão Examinadora do Programa de Pós-Graduação em Administração - PPGA/FACE/UnB, como requisito parcial para a obtenção do título de Mestre Profissional em Administração.
\end{abstract}

Aprovada em 21 de dezembro de 2015.

Professor Doutor João Mendes da Rocha Neto

Programa de Pós-Graduação em Administração

Universidade de Brasília

Orientador

Professor Doutor André Serrano

Programa de Pós-Graduação em Administração

Universidade de Brasília

Examinador Interno

Professora Doutora Andréia Santos Gonçalves

INEP/ MEC

Examinadora Externa 


\section{AGRADECIMENTOS}

Agradeço imensamente a toda a minha família, por compreender e aceitar os momentos de ausência nos eventos mais especiais, de nervosismo quando precisava descontrair e pela companhia e força que sempre me deram.

Agradeço, em especial, ao meu marido Alessandro, que esteve ao meu lado durante toda essa caminhada. Mesmo longe, esteve perto, se fez presente e abriu mão de sonhos pessoais para que realizássemos os nossos sonhos. Pela compreensão e pelo companheirismo ao longo desse ano que para nós foi tão difícil e conturbado, mas que também foi o mais marcante e feliz.

Agradeço a minha mãe, que sempre me apoiou, dando força e tranquilidade nos momentos de aflição em que me vi a ponto de retroceder.

Aos amigos da Secretaria de Educação do DF, que me apoiaram na decisão de sair de licença para cursar o mestrado, e, por isso, ter que abrir mão dos meus alunos. Porém não me esqueceram, estiveram sempre presentes em pensamento e palavras carinhosas.

Aos professores do PPGA, por toda a troca de conhecimento durante as aulas e ao meu orientador, João Mendes, que foi compreensivo e que tanto me ajudou na conclusão dessa etapa acadêmica.

Aos colegas do INEP, que contribuíram sobremaneira para a realização desse trabalho. Em especial ao Adolfo, que aceitou prontamente a participar da minha qualificação e tanto me ajudou com o seu vasto conhecimento sobre Avaliação. À Andreia Gonçalves, que além de chefe e amiga, acompanhou toda a minha trajetória; não pensou duas vezes e imediatamente aceitou participar da minha banca de defesa, mesmo com o pouco tempo, mas que com o seu conhecimento descomunal sobre a aplicação das avaliações torna esse momento ainda mais enriquecedor.

Não posso deixar de agradecer, por fim, a tão importantes amigos da vida toda, que compreenderam os momentos de ausência constante, sempre me incentivando e admirando o caminho que trilhei. 


\section{DEDICATÓRIA}

Esse trabalho é dedicado à minha querida família, ao meu marido e aos meus amigos de coração pelo amor e compreensão incondicionais. 


\section{RESUMO}

Este estudo teve como objetivo principal compreender de que forma os resultados das avaliações nacionais de alfabetização ANA e Provinha Brasil contribuem para o diagnóstico da alfabetização no Brasil e são utilizados pelos gestores estaduais de educação. Ambas as avaliações são aplicadas pelo Instituto Nacional de Estudos e Pesquisas Educacionais Anísio Teixeira (Inep) em diferentes etapas do ciclo de alfabetização do ensino fundamental. A ANA é a mais nova avaliação a compor o escopo do SAEB e deve ser aplicada ao final do $3^{\circ}$ ano do ensino fundamental, com vistas a indicar se os alunos estão alfabetizados aos oito anos de idade. Para tanto, realizou-se pesquisa com abordagem qualitativa, a partir da triangulação de métodos baseada na realização de grupo focal, entrevistas semiestruradas e análise documental. A pesquisa revelou que as avaliações proporcionam um retrato da alfabetização dos alunos brasileiros, mas ainda há grande dificuldade por parte de gestores, escolas e professores em utilizar seus resultados. Quanto à possibilidade de integração entre os resultados da ANA e da Provinha Brasil, a análise das matrizes de referência mostrou que isso não é possível de forma direta, já que elas estão em escalas diferentes e entregam diferentes produtos do processo de aprendizagem. Entretanto, para as Unidades da Federação que não dispõem de sistema próprio de avaliação, os resultados das avaliações nacionais são muito importantes, como única fonte de informação. Verificou-se que a influência dos resultados das avaliações na gestão de políticas públicas, como o próprio PNAIC, é incipiente e não há influência direta dos resultados das avaliações, ANA e Provinha Brasil, nas políticas educacionais desenvolvidas pelos Estados pesquisados.

Palavras Chaves: Avaliação; Avaliações em larga escala; Politicas Educacionais, ANA e Provinha Brasil. 


\begin{abstract}
This study aimed to understand how the results of national literacy ratings ANA and Provinha Brazil contribute to the diagnosis of literacy in Brazil and are used by state managers of education. Both assessments are implemented by the National Institute of Educational Studies Teixeira (INEP) at different stages of elementary school literacy cycle. The ANA is the newest assessment composing the scope of SAEB and should be applied at the end of the 3rd year of primary school, in order to indicate whether students are literate to eight years old. Therefore, it held research with qualitative approach, from triangulation methods based on conducting focus group, semiestruradas interviews and document analysis. The survey revealed that evaluations provide a portrait of literacy of Brazilian students, but there is great difficulty on the part of managers, schools and teachers to use their results. As for the possibility of integrating the results of the ANA and Provinha Brazil, the analysis of the reference arrays has shown that this is not possible directly, since they are in different scales and deliver different products of the learning process. However, for the Federative Units that do not have their own rating system, the results of national assessments are very important, as the sole source of information. It was found that the influence of evaluation results in the management of public policies, such as PNAIC own, are weak and there is no direct influence of evaluation results, ANA and Provinha Brazil, in education policy developed by the states surveyed.
\end{abstract}

Key words: Evaluation; Large-scale assessments; Educational Policies, ANA and Provinha Brazil. 


\section{LISTA DE QUADROS}

Quadro 1 - Taxa de escolarização de pessoas de 4 anos ou mais de idade 37

Quadro 2 - Sistemas de Avaliação Estaduais 39

Quadro 3 - Avaliações que compõem o SAEB - principais diferenças 42

Quadro 4 - Níveis da escala de proficiência da Provinha Brasil 2014 ..... 51

Quadro 5 - Números do PNAIC 54

Quadro 6 - Áreas de atuação dos participantes do grupo focal.. 59

Quadro 7 - Quantitativos previstos para aplicação da ANA 2013 64

Quadro 8 - Quantitativo de recursos interpostos contra os resultados da ANA 65

Quadro 9 - Quantitativo de recursos interpostos contra os resultados da ANA 2014

Quadro 10 - Percentual de alunos por UF, por nível de proficiência na ANA 2013 Leitura 70

Quadro 11 - Exemplos de níveis da escala de proficiência de Leitura da ANA 72

Quadro 12 -Percentual de alunos por UF, por nível de proficiência na ANA 2014 Leitura 72

Quadro 13 - Perfil dos entrevistados 85

Quadro 14 - Atividades na função de interlocutor 86 


\section{LISTA DE FIGURAS}

Figura 1 - Sistemas de Avaliação de Aprendizagem na América Latina............................ 32

Figura 2 - Evolução de UF que contam com testes avaliativos - 1992/2012 .................... 39

Figura 3 - Médias de proficiência em Língua Portuguesa - Brasil 1995-2005 ................. 42

Figura 4 - Evolução das metas do IDEB .................................................................. 44

Figura 5 - Exemplo de questão de Língua Portuguesa ................................................... 48

Figura 6 - Exemplo de questão de matemática ............................................................... 49

Figura 7 - Exemplo de ficha de correção da Provinha Brasil ........................................... 50

Figura 8 - Crianças não alfabetizadas aos oito anos por Região ..................................... 53

Figura 9 - Classificação dos usos da avaliação externa................................................ 61

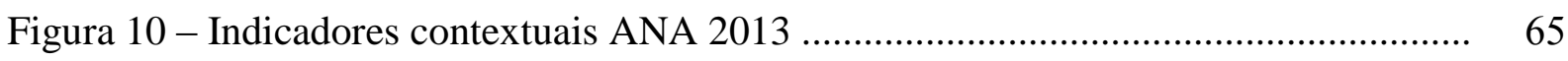

Figura 11 - Participação na avaliação ANA 2013 ....................................................... 66

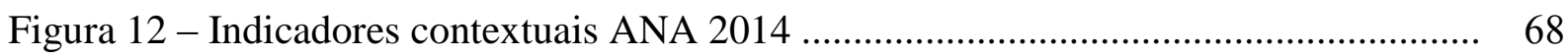

Figura 13 - Participação dos estudantes por escola ANA 2014 ........................................ 69

Figura 14 - Distribuição de estudantes por nível de proficiência em leitura ...................... 69

Figura 15 - Painel Educacional ANA ....................................................................... 70

Figura 16 - Percentual de alunos com aprendizado adequado em Língua Portuguesa ........ 73 


\section{LISTA DE APÊNDICES}

Apêndice I - Termo de Consentimento............................................................ 107

Apêndice II - Roteiro do Grupo Focal ........................................................ 108

Apêndice III - Roteiro de Entrevista _............................................................... $\quad 110$

Apêndice IV - Matrizes de Referência …........................................................... 112

Apêndice V - Escalas de Proficiência da ANA ....................................................... 118 


\section{SUMÁRIO}

INTRODUÇÃO

CAPÍTULO 1 - A EVOLUÇÃo DA POLÍTICA DE AVALIAÇÃO - DOS TESTES PADRONIZADOS À INSTITUCIONALIZAÇÃO DA AVALIAÇÃO DE POLÍTICAS PÚBLICAS

1.1 BREVE HISTÓRICO DA AVALIAÇÃO COMO POLÍTICA .......................................... 20

1.2 COMO ISSO SE DEU NO BRASIL? .................................................................... 23

1.3 CARACTERÍSTICAS DA AVALIAÇÃO DE POLÍTICAS _.......................................... 25

CAPÍTULO 2 - AVALIAÇÃO EDUCACIONAL NO BRASIL - HISTÓRICO E AVALIAÇÕES EM LARGA ESCALA ............................................................................ 27

2.1 SITUANDO HISTORICAMENTE A AVALIAÇÃO EDUCACIONAL ......................... 27

2.2 CARACTERIZANDO AS AVALIAÇÕES EM LARGA ESCALA .................................. 32

2.3 AS AVALIAÇÕES EM LARGA ESCALA E A QUESTÃO DA QUALIDADE ............... 35

2.4 AS AVALIAÇÕES DOS ENTES SUBNACIONAIS .................................................... 38

CAPÍTULO 3 - DOS RESULTADOS DO SAEB AO ESTABELECIMENTO DAS AVALIAÇÕES DE ALFABETIZAÇÃO: PROVINHA BRASIL E ANA........................... 41

3.1 PROVINHA BRASIL: AVALIAÇÃO DIAGNÓSTICA DA ALFABETIZAÇÃO ........... 46

3.2 AVALIAÇÃO NACIONAL DA ALFABETIZAÇÃO .................................................... 52

CAPÍTULO 4 - MÉTODOS, PROCEDIMENTOS E TÉCNICAS DE PESQUISA ........ 56

4.1 DESENHO E TIPIFICAÇÃO DA PESQUISA .............................................................. 56

4.2 PARTICIPANTES: DELIMITAÇÃO DA AMOSTRA ………………………………...... 57

4.3 PROCEDIMENTOS DE COLETA E ANÁLISE DE DADOS ........................................ 57

CAPÍTULO 5 - ANÁLISE E DISCUSSÃO DOS RESULTADOS DA PESQUISA........... 63

5.1 COMPREENDENDO A METODOLOGIA DE APLICAÇÃO E DIVULGAÇÃO DE

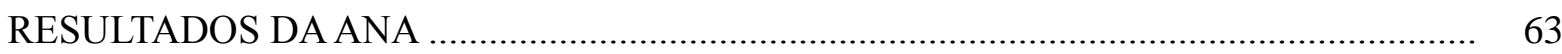

5.2 ANÁLISE COMPARADA DAS MATRIZES DE REFERÊNCIA ……………………..... 75

5.3 PERCEPÇÕES DE ESPECIALISTAS EM AVALIAÇÕES EDUCACIONAIS.................. 80

5.4 COMO OS RESULTADOS DA ANA SÃO UTILIZADOS PELOS GESTORES ESTADUAIS DE EDUCAÇÃO .................................................................................... 85

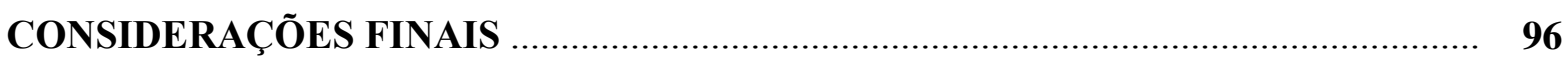

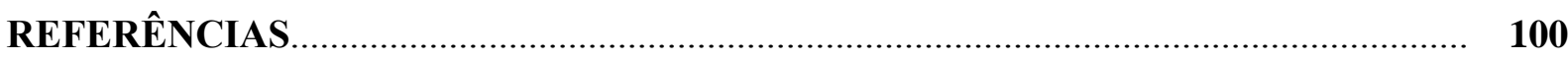

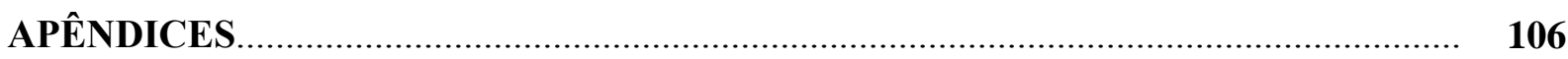




\section{INTRODUÇÃO}

O mundo assistiu, desde o final dos anos 1920 ao início dos anos 1980, às diversas crises enfrentadas pelo sistema capitalista que afetaram profundamente todas as instituições, bem como suas formas de organização. Isso ocasionou uma intensa transformação nas estruturas dos Estados Nacionais, acarretando processos de redefinição de seus papéis e configurando novos modelos de funcionamento estatais.

Oliveira (2011) aponta para a importância de dois momentos cruciais de crise do sistema capitalista que impactaram no processo de reconfiguração sofrido pelos Estados nacionais: a "grande depressão", em 1929, e a crise do petróleo, na década de 1970. Não se pretende, nesse trabalho, abordar mais detidamente as implicações de cada um desses momentos para as transformações dos Estados nacionais, porém cumpre-se destacar, ainda que de maneira sucinta, as principais consequências para as reformas e impactos nas políticas sociais.

No Brasil, a avaliação de políticas e programas públicos ganhou um lugar de destaque como meio para mensurar o desempenho e exercer a prestação de contas à sociedade (BONAMINO; SOUSA, 2012), evidenciando-se, cada vez mais, a importância dada às avaliações em larga escala no diagnóstico da qualidade da educação brasileira e seu papel fundamental na elaboração e acompanhamento de políticas públicas. Nessa perspectiva, de acordo com Bonamino e Sousa (2012, p. 378), “[...] a avaliação aparece diretamente ligada ao desempenho da gestão pública, à promoção de maior transparência e à criação de mecanismos de responsabilização".

A avaliação, como campo do conhecimento fundamental para o monitoramento das políticas e para orientação de intervenções no campo educativo (DOURADO; OLIVEIRA; SANTOS, 2007), ganhou destaque nos últimos 20 anos, quando a avaliação sistêmica tornouse o instrumento regulador prioritário das políticas estatais. (OLIVEIRA, 2011)

Para Cotta (2001, p. 94) avaliar significa “[...] formar um juízo de valor com base na comparação entre uma situação empírica e uma situação ideal". No que tange ao ato de avaliar a ação educacional, Freitas et al. (2009) distinguem três níveis de avaliação: a avaliação da aprendizagem, realizada na sala de aula pelo professor, a avaliação institucional escolar, feita em cada escola pelo seu coletivo, e a avaliação em larga escala em redes de ensino, que pode ser realizada em âmbito municipal, estadual ou federal. Todos os níveis de avaliação deveriam articular-se no intuito de promover melhorias na educação. 
Para Dourado, Oliveira e Santos (2007, p. 10), a avaliação é considerada “[...] fundamental para o monitoramento das políticas e para orientar as intervenções no campo educativo". Gomes Neto e Rosenberg (1995) coadunam com a perspectiva de criação de sistemas de avaliação como forma de orientação e monitoramento das políticas educacionais, de modo a apoiar ações em favor da melhoria da qualidade de ensino.

Nessa direção, diferentes países iniciaram reformas em seus sistemas educacionais com a finalidade de torná-los mais eficientes e equitativos (MELLO, 1992). Segundo Faria (2005), em decorrência da necessidade de modernização da gestão pública em um contexto de busca de dinamização e legitimação da reforma do Estado. "Nas entrelinhas dessa reforma educacional, aparece a conexão entre a competitividade internacional, a produtividade individual e a melhoria na qualidade da Educação". (BROOKE; CUNHA, 2011, p. 17).

Porém, até fins da década de 1970, a avaliação não fazia parte da agenda pública brasileira, já que as políticas educacionais estavam voltadas para a expansão do atendimento e a promoção do acesso ao sistema educacional e a qualidade ainda não havia emergido como uma questão relevante (COTTA, 2001, p. 90).

Segundo Cotta (2001), a partir da década de 1980, esse cenário começa a se modificar com a crescente preocupação de organismos internacionais com a qualidade do ensino e a implantação de sistemas de avaliação em larga escala em diversos países latino-americanos, criando, assim, as condições para que o tema adquirisse maior visibilidade no Brasil.

Faria e Filgueiras (2003, p. 1) destacam que “[...] a institucionalização de sistemas de avaliação da educação, principalmente da educação básica, são elementos centrais dessa vaga reformista", a qual pode estar relacionada tanto com a reconfiguração dos sistemas de proteção social dos países latino-americanos quanto à própria questão da reforma do Estado na região.

Dessa maneira, as reformas da década de 1990 deixaram claro que os governos “[...] enxergavam a qualidade como um ingrediente necessário à modernização e ao desenvolvimento e os sistemas de avaliação como os guardiões dos esforços de melhoria" (BROOKE; CUNHA, 2011, p. 17). Ainda segundo os autores, os modelos de reformas instituídas nos Estados Unidos e na Grã-Bretanha a partir da década de 1980, foram fortemente propagados por organismos internacionais e serviram para elevar o status da avaliação educacional mundialmente. 
No Brasil, é possível perceber mais claramente, a partir da década de 1990, a intenção do Governo Federal na busca por resultados que pudessem servir como base para implantação e gestão de novas políticas educacionais. A avaliação ganhou relevância como política de Estado, em todo o mundo, a partir da Conferência de Educação para Todos, realizada em Jontien, na Tailândia, e que impulsionou a elaboração do Plano Decenal de Educação para Todos, em 1993, que previa uma série de ações para melhorar a educação brasileira (HORTA NETO, 2006).

O Plano ressaltou a importância de uma avaliação nacional como forma de medir a qualidade do ensino. Qualidade, essa, expressa na Constituição, ao definir educação como:

[...] direito de todos e dever do Estado objetivando o desenvolvimento da pessoa para o exercício da cidadania, com o ensino ofertado a partir de princípios que garantam, entre outros, igualdade de condições de acesso e permanência nas escolas, além da garantia de padrão de qualidade. (CF, art. 205 e 206).

Assim, a garantia do direito à educação de qualidade passa a ser considerado um princípio fundamental para as políticas e gestão da educação (BRASIL, 2013b).

Porém, o panorama brasileiro é marcado por desigualdades regionais no acesso e permanência de estudantes à educação, exigindo uma maior organicidade das políticas educacionais, por meio da construção do Sistema Nacional de Educação (SNE) e do Plano Nacional de Educação - PNE, como políticas de Estado. Nesse sentido:

As discussões sobre a necessidade de definição de políticas públicas para educação e
alfabetização se intensificaram já no final da década de 1980, como resultado do
processo de redemocratização do país que culminou com a elaboração da
Constituição brasileira de 1988. No entanto, foi nas décadas de 1990 e 2000 ,
especialmente a partir da votação, pelo Congresso Nacional, em 2001, do Plano
Nacional de Educação (PNE), que governos brasileiros - com crescente pressão e
participação crítica e propositiva de segmentos organizados da sociedade civil, com
crescente parceria também (MORTATTI, 2013, p.19).

Sass e Minhoto (2011) destacam que a avaliação educacional no Brasil passou por uma série de transformações até ser caracterizada como o principal instrumento de verificação da expansão, atendimento, eficácia e eficiência, especialmente do sistema público de ensino.

Além de outros objetivos, as iniciativas de avaliação associam-se à promoção da qualidade do ensino, estabelecendo, no limite, novos parâmetros de gestão dos sistemas educacionais (BONAMINO; SOUSA, 2012). Como o sistema educacional visa a universalização do acesso, à equidade e à qualidade do ensino, a avaliação deverá verificar se esses objetivos estão sendo atingidos (GOMES NETO; ROSENBERG, 1995). 
O Ministério da Educação passou a incentivar estudos sobre avaliação do rendimento escolar, estimulado, principalmente, pelas discussões com as agências internacionais como o Banco Mundial, que tinha em quase todos os acordos assinados um componente de avaliação educacional, visando a efetividade das ações (GOMES NETO; ROSENBERG, 1995). Seu objetivo é fornecer diagnóstico e subsídios para a implementação ou manutenção de políticas educacionais e deve ser concebida para prover o monitoramento do sistema educacional a fim de detectar os efeitos positivos ou negativos de políticas adotadas (KLEIN, 1995).

Considerando a importância da qualidade da educação oferecida pelas escolas, foram desenvolvidos programas de avaliação do sistema educacional e a primeira experiência realizada foi o Programa de Educação Básica do Nordeste Brasileiro (Edurural) ${ }^{1}$.

A partir dessa experiência, foram construídas as bases para o Sistema Nacional de Avaliação da Educação Básica - SAEB, que foi instituído em 1988 com o objetivo de avaliar a qualidade do ensino oferecido pelo sistema educacional brasileiro a partir de testes padronizados e questionários socioeconômicos. O SAEB representou o início da trajetória de avaliação em larga escala no Brasil e passou por diversas mudanças até se consolidar no modelo de aplicação de dois instrumentos ANEB e Prova Brasil.

Dessa forma, a partir de 2007, com a publicação do Plano de Desenvolvimento da Educação - PDE e do "Compromisso Todos pela Educação", o Brasil estabeleceu metas para a educação e desenvolveu ações que contribuíssem para o alcance de tais metas.

Entre elas a criação do Índice de Desenvolvimento da Avaliação Básica - IDEB, que combina o desempenho dos alunos na Prova Brasil e as taxas de aprovação calculadas a partir de dados do Censo Escolar. O país tinha o seu principal indicador da qualidade da educação básica e estava criada a referência para o estabelecimento de parâmetros para a melhoria da qualidade do ensino. (FERNANDES; GREMAUD, 2009)

No mesmo ano, foi instituída a Provinha Brasil a partir da Portaria Normativa $n^{\circ} 10$, de 24 de abril de 2007, com a finalidade de avaliar o nível de alfabetização dos educandos nos anos iniciais do ensino fundamental (BRASIL, 2007). Como medida para auxiliar as redes de ensino a produzirem um diagnóstico precoce dos níveis de alfabetização de seus alunos, que mais tarde seriam avaliados pelo SAEB, a Provinha Brasil estava em consonância com o Plano de Metas e com o PDE.

\footnotetext{
${ }^{1}$ Programa de Educação Básica para o Nordeste Brasileiro, implementado em 1980 com o objetivo de expandir o acesso às quatro primeiras séries, diminuir a evasão e repetência e melhorar o rendimento escolar dos alunos de municípios menos desenvolvidos. Contava com uma avaliação de rendimento escolar para medir o impacto do programa junto aos municípios participantes.
} 
Posteriormente, o Ministério da Educação instituiu, pela Portaria $n^{\circ} 867$, de 4 de julho de 2012, o Pacto Nacional de Alfabetização na Idade Certa - PNAIC, uma iniciativa do Governo Federal que conta com a adesão dos estados, Distrito Federal e municípios para que todas as crianças estejam alfabetizadas até os oito anos de idade, ao final do $3^{\circ}$ ano do ensino fundamental.

Um dos eixos estruturantes do PNAIC é a Avaliação, composto por três elementos: avaliações processuais discutidas nos cursos de formação e desenvolvidas continuamente pelos professores junto aos alunos; sistema informatizado que deverá ser preenchido pelos professores com o resultado da Provinha Brasil de cada aluno no início e ao final do $2^{\circ}$ ano do ensino fundamental; e a aplicação de uma avaliação ao final do $3^{\circ}$ ano do ensino fundamental, censitária e coordenada pelo Instituto Nacional de Estudos e Pesquisas Educacionais Anísio Teixeira - INEP, com o objetivo de avaliar o nível de alfabetização alcançado pelas crianças. (BRASIL, 2012).

Nesse contexto é criada a Avaliação Nacional de Alfabetização - ANA, objeto de estudo desta dissertação, com o objetivo de aferir o nível de alfabetização e letramento em Língua Portuguesa e alfabetização em Matemática das crianças regularmente matriculadas no $3^{0}$ ano do ensino fundamental e as condições de oferta das instituições às quais estão vinculadas (BRASIL, 2013). Para tanto, a ANA prevê a aplicação de testes de desempenho juntamente com questionários contextuais para a análise das condições de escolaridade dos alunos.

Atualmente, observa-se a grande ênfase que tem sido dada à avaliação externa com a criação de novos instrumentos, como a ANA. Para avaliar a educação básica, verifica-se a existência do SAEB, dividido em ANEB e Prova Brasil, a Provinha Brasil (em duas etapas), a ANA, o Exame Nacional do Ensino Médio - Enem, e ainda a Prova ABC aplicada nos anos de 2011 e 2012. Ademais vários estados e municípios tem organizados seus próprios sistemas de avaliação de aprendizagens.

Todas essas iniciativas, segundo CASTRO, (2009, p. 6) "indicam a progressiva institucionalização da avaliação como mecanismo importante para subsidiar o processo de formulação e monitoramento de políticas públicas responsáveis e transparentes que devem nortear o aprimoramento de ações de melhoria da aprendizagem".

$\mathrm{Na}$ literatura especializada, observa-se a existência de estudos que buscam qualificar os usos de tais instrumentos no âmbito do processo decisório das secretarias de educação, sempre com foco no SAEB, como nas pesquisas dos autores (SOUSA; OLIVEIRA, 2010; 
BONAMINO; SOUSA, 2012; BROOKE; CUNHA, 2011; GIMENES et al. 2013).

Porém, estudos como de Oliveira, Horta Neto e Moura (2011, 2013, 2014) destacam o baixo efeito que as avaliações externas em larga escala têm provocado no cotidiano das escolas, nas mudanças das práticas pedagógicas e na melhoria efetiva da qualidade da educação. Nessa perspectiva, Castro (2009) defende que ainda é insipiente o uso dos resultados das avaliações ao afirmar:

[...] se é verdade que o Brasil avançou na montagem e consolidação dos sistemas de avaliação, é também verdade que ainda não aprendemos a usar, de modo eficiente, os resultados das avaliações para melhorar a escola, a sala de aula, a formação de professores. Este, aliás, é um dos grandes desafios das políticas educacionais, sem o qual o objetivo principal da política de avaliação perde sentido para os principais protagonistas da educação: alunos e professores. (CASTRO, 2009, p.7)

Dessa maneira, faz-se necessário o estudo sobre as formas de apropriação dos instrumentos avaliativos por instâncias de gestão educacionais, bem conhecer quais são, de fato, os usos e os efeitos realizados a partir de seus resultados. Para Brooke e Cunha (2011), é necessário refletir a necessidade de controlar mais detidamente as etapas que envolvem o processo de avaliação e, assim, traçar um diagnóstico mais contextual da aprendizagem dos alunos para, com base nisso, elaborar instrumentos e estratégias mais eficazes.

Portanto, se as avaliações ainda não conseguiram provocar mudanças substanciais na prática pedagógica das escolas, e tendo em vista que a ANA não é a primeira avaliação externa aplicada para aferir os níveis de alfabetização nas séries iniciais, algumas questões e inquietações são colocadas nesta pesquisa:

- É possível construir um diagnóstico da alfabetização a partir dos resultados da ANA?

- É possível equalizar os resultados da ANA e da Provinha Brasil aplicadas durante o ciclo de alfabetização?

- Qual o uso que gestores públicos estão fazendo de seus resultados?

Nesse sentido, dessas inquietações emergiu a questão central à qual constituiu a pergunta de pesquisa que o referido estudo procurou responder: De que maneira os resultados das avaliações de alfabetização ANA e Provinha Brasil estão sendo utilizados e contribuem para compor um bom diagnóstico da alfabetização no Brasil?

O objetivo geral da pesquisa é compreender de que forma os resultados das avaliações de alfabetização ANA e Provinha Brasil estão sendo utilizados por gestores estaduais no diagnóstico da alfabetização. 
Para o alcance do objetivo geral, foram definidos os seguintes objetivos específicos:

a) Compreender o funcionamento da metodologia de aplicação e de apresentação de resultados da Avaliação Nacional da Alfabetização - ANA, como novo instrumento de avaliação da alfabetização.

b) Comparar as matrizes de referência e os níveis de proficiência das avaliações Provinha Brasil e ANA.

c) Investigar de que forma os resultados da Provinha Brasil e da ANA são disseminados.

d) Examinar a percepção dos interlocutores ${ }^{2}$ estaduais acerca dos resultados da ANA e da Provinha Brasil.

Ressalta-se que já há estudos acerca do uso dos resultados do SAEB e do emprego pedagógico que se faz deles. Porém, por se tratar de uma nova forma de análise, não há ainda estudos acadêmicos que se debrucem sobre a Avaliação Nacional da Alfabetização - ANA, portanto, esse trabalho contribui para desvelar o contexto das avaliações de alfabetização e analisar as possibilidades de utilização dos seus resultados na perspectiva de gestores estaduais de educação.

A pesquisa constitui-se, primeiramente, no levantamento da produção científica afeta ao tema Avaliação, com ênfase em estudos sobre avaliação educacional, no qual se procurou mapear os principais autores referenciados na área de conhecimento. Posteriormente, foi realizado o levantamento da legislação tal como Portarias, Leis e Decretos que auxiliaram na compreensão histórica dos modelos de avaliações externas aplicadas no Brasil. Para a compreensão de como as avaliações em larga escala foram institucionalizadas e são operacionalizadas pelo Governo Federal, houve análise minuciosa de documentos oficiais e documentos técnicos, tais como Notas Técnicas, Relatórios, Estudos e Publicações, pesquisados diretamente no INEP e disponibilizados nos sítios oficiais do INEP, MEC e das Secretarias Estaduais de Educação. Tal análise permitiu mapear a metodologia de aplicação da ANA e da Provinha Brasil, bem como, estabelecer relação entre as matrizes de referência e níveis de proficiência de ambas as avaliações.

A segunda parte da pesquisa tratou-se de estudo empírico realizado com servidores do Inep e interlocutores das Secretarias Estaduais de Educação. Junto aos servidores do Inep, técnicos e especialistas em avaliações educacionais, foi realizado o método de pesquisa qualitativa Grupo Focal, que consiste em uma entrevista em grupo que busca captar a

\footnotetext{
${ }^{2}$ Nomeados pelo Inep o para acompanhamento de assuntos técnico pedagógico relativos às avaliações da educação básica.
} 
percepção dos participantes a partir de sua interação. O objetivo da técnica foi verificar a percepção dos servidores do Inep acerca da concepção da ANA como componente estruturante do PNAIC e a possibilidade de construção de um diagnostico de alfabetização a partir de seus resultados. Junto aos interlocutores do Inep que estão diretamente envolvidos com a concepção das avaliações da educação básica, bem como sua operacionalização e divulgação de resultados em seus respectivos Estados, foram realizadas entrevistas semiestruturadas, com a definição de um roteiro prévio, e coletada a percepção desses interlocutores acerca dos usos dos resultados das avaliações externas nacionais de alfabetização em seus estados.

Dessa forma a presente dissertação está organizada em cinco capítulos a partir desta Introdução, sendo o primeiro acerca da evolução da política de avaliação com a retomada histórica de seu papel até se tornar um importante instrumento de aferição da qualidade dos serviços públicos. O segundo capítulo trata da avaliação educacional com foco nas avaliações em larga escala até a configuração do Sistema de Avaliação da Educação brasileiro. O terceiro capítulo contextualiza o SAEB e descreve como as avaliações de alfabetização passaram a compor a agenda pública de políticas educacionais. No quarto capítulo encontra-se a descrição dos procedimentos metodológicos de coleta e análise dos dados e o quinto capítulo traz a discussão dos resultados encontrados na pesquisa, concluindo-se com as considerações finais. 


\section{A EVOLUÇÃO DA POLÍtiCA DE AVALIAÇÃO - DOS TESTES PADRONIZADOS À INSTITUCIONALIZAÇÃO DA AVALIAÇÃO DE POLÍTICAS PÚBLICAS}

O objetivo do primeiro capítulo é apresentar historicamente o caminho percorrido pela avaliação até se consolidar como uma política governamental capaz de promover ajustes nas políticas públicas desenvolvidas pelos Estados nacionais. Para tanto, admite-se para a presente pesquisa o entendimento de que esta verificação periódica tornou-se uma política estatal estratégica, principalmente nos anos 1990, fruto do desenvolvimento do neoliberalismo. O capítulo situa a avaliação e traça sua trajetória até ser reconhecida, institucionalizada e utilizada a serviço da qualidade dos serviços públicos.

\subsection{BREVE HISTÓRICO DA AVALIAÇÃO COMO POLÍTICA}

O processo histórico de evolução da pesquisa avaliativa pode ser identificado a partir de três estágios, de acordo com Shadish at al. apud Silva (2012, p.223). O primeiro situa-se nos anos 1960, marcado pela preocupação com a aplicação de rigorosos métodos científicos para resolução de problemas sociais. O segundo está situado nos anos 1970, cuja ênfase foi a utilização da avaliação no processo decisório sobre a concepção, alteração ou continuidade de programas, com primazia da utilização de técnicas de avaliação quantitativas em oposição a técnicas qualitativas. O terceiro e último estágio, para os autores, constitui a síntese dos estágios anteriores.

Já Guba e Lincoln apud Faria (2005, p. 99) descrevem a emergência de quatro gerações de pesquisas avaliativas tendo como foco os Estados Unidos e fazendo uma caracterização desde os anos de 1930, sendo: 1) um início com um viés mais técnico, no período do New Deal; 2) uma "geração" mais "descritiva", predominante desde a Segunda Guerra Mundial até meados da década de 1960; 3) uma que enfatizava a oferta de "julgamentos" abalizados, prevalecente entre meados dos anos de 1960 e meados da década seguinte, ou seja, quando da avaliação dos polêmicos programas da "Guerra à Pobreza" (War on Poverty) e da "Grande Sociedade" (Great Society); e, finalmente, 4) uma "geração" "reativa", característica dos anos Reagan.

Durante a década de 1960, nos Estados Unidos, ocorreu um grande movimento de avaliação de políticas e programas públicos devido à expansão sem precedentes do gasto público com bens e serviços sociais. Porém, a avaliação era vista, quase que exclusivamente, 
como uma ferramenta de planejamento destinada aos formuladores de políticas e aos gerentes de mais alto nível (FARIA e FILGUEIRAS, 2003). Os autores destacam que:

Em seus primórdios nos anos 1960 a avaliação era marcada pela falácia mecanicista do planejamento top-down, ou seja, esperava-se uma utilização automática de seus resultados, numa perspectiva quase exclusivamente instrumental, como baliza do processo decisório e como ferramenta para a resolução racional de problemas. (Idem, p.7).

Assim, as instituições financiadoras passaram a exigir que as políticas sociais fossem mensuradas como condição para o seu financiamento. Recomendou-se, ainda, maior racionalidade e rendimento do gasto público, com critério de aferição da eficiência na utilização dos recursos e da eficácia na busca de verificar o alcance dos objetivos preestabelecidos. Considerando a primeira fase das pesquisas avaliativas em que prevalecia a racionalidade e adoção de métodos científicos rígidos para a análise e resolução de problemas sociais, destacam-se os estudos de Donald Campbell, considerado um dos primeiros teóricos da avaliação reconhecido pela literatura, com seu trabalho baseado na investigação experimental; a importante influência de Michel Scriven para o campo, que defendia que as práticas de análise deveriam ser externas aos interesses dos programas e capazes de apontar soluções eficazes aos problemas sociais; além de Lee Chonbach, que defendia uma metodologia pluralista e criticava a submissão dos avaliadores aos gestores que controlavam os procedimentos analíticos (PRESTES, 2012).

São proeminentes também as contribuições de Robert Stake, precursor da teoria avaliativa participativa, na utilização de metodologia de estudo de caso e da defesa de generalizações naturalistas; Carol Weiss, uma das primeiras investigadoras da avaliação das políticas sociais, adotou o pragmatismo metodológico nos processos avaliativos e defendeu que o avaliador deveria dispor de informações empíricas e de explicações sobre o objeto e o contexto político avaliado para torná-lo capaz de responder aos objetivos da avaliação; e o enfoque inovador proposto por Ernest House, que entendia que a avaliação não produz conhecimentos certos, e seus atos são de persuasão e de argumentação e não de demonstração. (VIANNA, 2005).

Segundo Albaek apud Faria (2005, p. 98), na década de 1970 avolumaram-se as evidências acerca do excesso de otimismo quanto à plena utilização e incorporação dos resultados das avaliações. Ganhou espaço, então, o desenvolvimento de abordagens e metodologias botton-up.

Faria (2005) apresenta, ainda, outra concepção acerca das motivações do Estado para a 
valorização da avaliação de políticas, sugerida em estudos de Derlien (2001), no qual o papel da avaliação se associa diretamente ao conceito de realocação, superando-se assim a função de informação predominante até a década de 80, tendo "[...] os avaliadores se convertido em auditores que privilegiavam a medição dos resultados" com fins na supressão, redução ou reorganização de programas e atividades públicas (p. 99).

Durante os anos 1980 e 1990, verificou-se uma série de reformas para conter a crise produzida desde a década de 1970 com as políticas keynesianas do Estado de Bem-Estar Social, que já vinham mostrando sinais de esgotamento e necessidade de transformação (CHELI, 2009). Como medidas para a crise, a promoção do ajuste fiscal, a liberalização do comércio e as privatizações estavam em sintonia com as políticas que se aplicavam mundialmente (CHELI, 2009).

Como destaca Dalben (2002), advém da crise do capitalismo a consolidação do neoliberalismo, onde o Estado muda de provedor de serviços à sociedade, para controlador e avaliador:

\begin{abstract}
Os problemas advindos da crise do petróleo na década de 70 acarretaram uma série de necessidades e, consequentemente, de mudanças no encaminhamento das políticas públicas das diferentes nações. Houve necessidade de cortes de orçamentos e mudanças nos discursos que justificavam esses cortes, promovendo um campo frutífero às ideias neoliberais de alteração do papel do Estado de provedor de bens e serviços para avaliador e controlador. (p. 6)
\end{abstract}

Ganha força o ideal liberalista, e o Estado passa a ser visto como o Estado mínimo que deve garantir os direitos de propriedade, deixando ao mercado a coordenação da economia. CHELI (2009) explica como esse contexto contribui para alterar a forma como o Estado passa a se relacionar com o mercado e a exercer sua nova função regulatória:

Estas reformas, denominadas neoliberales o de mercado tenían como premisa la reducción del Estado a su capacidad mínima de agente controlador del sistema pero sin intervención en el mercado, la "mano invisible del mercado" regularía las relaciones.(p. 67)

Os dois excertos deixam clara a transformação do papel do Estado, de uma posição de provedor de políticas e programas sociais para um Estado mínimo, regulador dos serviços públicos. A ideia de avaliação, então, associou-se às propostas de reforma do Estado que, como alternativas ao modelo burocrático de administração, convergiram para a administração pública gerencial, enfatizando a transparência e a qualidade dos serviços (PAES-SOUSA e VAITSMAN, 2007).

De acordo com Paes-Sousa e Vaitsman (2007), passou-se a advogar pela necessidade de procedimentos e métodos que possibilitassem medir e avaliar várias dimensões dos 
serviços prestados pelo governo. É justamente o papel da avaliação como instrumento de gestão capaz de produzir accountability que dá ao termo "político" o significado positivo de produzir transformações na operação da gestão pública.

A demanda por avaliação de programas sociais amplia-se, constituindo-se também como exigências dos organismos internacionais, como o Banco Mundial e o Banco Interamericano de Desenvolvimento, no contexto de reforma dos programas sociais, pautada pela focalização, descentralização e privatização (SILVA, 2012, p. 223).

A execução dos programas sociais é largamente transferida para organizações do chamado terceiro setor, visto como menos burocratizado, mais eficiente e mais dinâmico que a estrutura do Estado (PEREIRA; GRAU, 1999). Assim, a avaliação dos programas sociais se transforma em mecanismo fundamental de controle do Estado sobre os recursos que são transferidos para o terceiro setor, implementadores privilegiados de programas sociais (SILVA, 2012, p. 109).

\subsection{COMO ISSO SE DEU NO BRASIL?}

No Brasil, a expansão da avaliação de políticas e programas sociais é registrada a partir dos anos 1980, no contexto das lutas sociais contra a ditadura militar, implantada em 1964, por demanda dos movimentos sociais que colocaram na agenda pública a necessidade de expansão de políticas sociais universais enquanto direito de cidadania. Nessa conjuntura, amplia-se a crítica ao padrão de políticas sociais desenvolvidas na América Latina e no Brasil, sobretudo quanto ao mau uso do dinheiro público e à desfocalização dos programas sociais na população mais necessitada. Vive-se, então, um processo de reestruturação produtiva por exigência da crise fiscal do Estado e por influência do projeto neoliberal, assumido tardiamente a partir dos anos 1990. Nesse processo de reforma, o formato do Estado, de interventor (executor), passa a mantenedor (financiador) e a regulador (elaborador de normas e controle).

De acordo com Oliveira (2011) a influência neoliberalista evidencia-se no Brasil após o mandato presidencial de Fernando Collor de Mello de 1989 a 1992, consolidando-se com os mandatos consecutivos de Fernando Henrique Cardoso de 1995 a 2002. No período presidencial de FHC ganham força as críticas acerca da ineficiência do Estado e a falta de qualidade da condução do país rumo ao desenvolvimento econômico.

A relação entre a qualidade das ações dos governos, os controles e incentivos a que 
estão submetidos os governantes e a burocracia ganham relevância, bem como o fortalecimento dos mecanismos de responsabilização e o aperfeiçoamento das práticas administrativas. Dois deles ganham destaque como formas de participação e controle sobre as ações do Estado: o controle social e o controle de resultados (BONAMINO; SOUSA, 2012).

Sob o argumento da falta de qualidade dos serviços públicos e a necessidade de implantação de um novo modelo de gestão, as autoridades brasileiras defenderam uma reforma estatal centrada no modelo gerencial. (Oliveira, 2011, p. 42).

Uma das mais polêmicas ações desse novo modelo foi medir o desempenho e resultados da administração pública e, com isso, buscar a melhoria dos serviços prestados, dar publicidade e transparência de custos e resultados e fortalecer os pilares da governança em rede (PACHECO, 2010). Segundo a autora, a polêmica deve-se ao fato de que mensuração do desempenho no setor público traz algumas consequências negativas, porém pode significar o acompanhamento da sociedade sobre as ações do governo e formas bem-sucedidas de accountability democrática.

Para tanto, e em consonância com o novo modelo, em 1995, houve a criação do Ministério da Administração Federal e Reforma do Estado (Mare), responsável por sistematizar e coordenar a reforma operacionalizada, mais tarde pelo Plano Diretor da Reforma do Aparelho do Estado. (OLIVEIRA, 2011)

No Estado democrático, os resultados devem estar alinhados às escolhas da sociedade e prover serviços com qualidade e eficiência (PACHECO, 2010). Nessa perspectiva, a avaliação de políticas e programas públicos adquire um lugar de destaque como meio para mensurar seu desempenho e exercer a prestação de contas à sociedade ligada diretamente à performance da gestão pública, à promoção de maior transparência e à criação de mecanismos de responsabilização. (BONAMINO; SOUSA, 2012)

A institucionalização de diferentes mecanismos de accountability, dentre os quais a avaliação, passou a compor o arcabouço governamental dos Estados democráticos, pressupondo também diferentes mecanismos de prestação de contas. (PAES-SOUSA; VAITSMAN, 2007). No Brasil os sistemas de avaliação integrados às estruturas governamentais passaram a ser adotados como instrumentos para melhorar a gestão das políticas e dos programas sociais.

De acordo com Clímaco (2005) apud Oliveira (2011, p. 55), nessa vaga reformista, a avaliação integrava o processo de mudança da gestão. Para tanto, elencou alguns dos fatores que a tornam indispensável aos governos, como: 1) aperfeiçoamento das políticas, programas 
e projetos; 2) controle dos níveis de satisfação dos cidadãos pelos serviços prestados; 3) fundamentação e legitimação das decisões políticas, principalmente que envolvam recursos; 4) prestação de contas dos serviços ofertados; 5) responsabilização dos envolvidos pelos resultados dos serviços; 6) produção de conhecimentos e informações aos governantes, técnicos e membros da sociedade civil e científica.

Segundo Oliveira (2001), a reforma da administração pública brasileira atendendo à pressão por qualidade dos serviços estatais fortaleceu as funções de regulação e de controle do Estado, além de descentralizar a execução de serviços sociais às instâncias estaduais e municipais. Nesse sentido, a autora destaca, ainda, o surgimento do novo modelo de Estado, denominado "Estado avaliador".

Paes-Sousa e Vaitsman (2007) destacam, ainda, a importância de se diferenciar atividades de controle e de avaliação, que às vezes são confundidas uma com a outra. "O foco das atividades de avaliação e monitoramento é a qualidade da gestão, enquanto o das atividades de controle é a legalidade dos atos da administração pública" (PAES-SOUSA; VAITSMAN, 2007. p. 12).

Para os autores, (2007, p.12), “o objetivo mais geral da avaliação é a produção de informação qualificada e sistematizada sobre programas, políticas, ações, serviços.” Aliada à rotina de execução as políticas públicas, ela tem por finalidade subsidiar tomadas de decisões e ações de um conjunto de atores interessados. As avaliações são capazes de gerar insumos que possibilitem o melhor desempenho dos programas e o alcance de metas. (PAES-SOUSA E VAITSMAN, 2007).

\subsection{CARACTERÍSTICAS DAS AVALIAÇÕES DE POLÍTICAS}

Avaliações de programas podem ser feitas por meio de diferentes tipos de estudos, que observam várias dimensões, tais como relevância, eficiência, efetividade, resultados e impactos. Espera-se que as indicações desses estudos contribuam para melhorar a qualidade dos processos de implementação ou verificar os resultados dos programas, dando também subsídios para o planejamento, a programação e a tomada de decisões futuras (PAES-SOUSA; VAITSMAN, 2007, p. 12).

Considerando as dimensões que envolvem a avaliação de políticas e programas sociais, SILVA (2012, p. 114) elege três funções para a avaliação:

- Função técnica: a) fornecer subsídios para correção de desvios no decorrer do 
processo de implementação; b) indicar em que medida objetivos e mudanças ocorreram; c) subsidiar a elaboração ou redimensionamento de políticas e programas sociais;

- Função política: oferecer informações para sujeitos sociais fundamentarem lutas sociais no campo das políticas públicas (controle social); e

- Função acadêmica: desvelar as determinações e contradições presentes no processo das políticas públicas, evidenciando os significados mais profundos dessas políticas (sua essência) para a construção do conhecimento.

A escolha dos desenhos de estudos de avaliação e, consequentemente, dos métodos dependerá das perguntas que se quer responder, dos recursos e das fontes de dados disponíveis e do tempo de resposta desejado. Draibe apud Paes-Sousa e Vaitsman (2007, p. 12) estabelece a seguinte tipologia quanto às dimensões que podem ser abordadas pelos estudos de avaliação:

a) processos - estudos sobre os pontos que favorecem ou dificultam os processos de implementação da política ou do programa. Os resultados das avaliações de processos podem ser mais facilmente utilizados por gestores e gerentes, que têm a possibilidade de tomar providências em relação a achados e recomendações pertinentes.

b) resultados - englobam desempenho, que se refere aos produtos definidos pelas metas do programa, e impacto, que indica mudança na situação dos beneficiários, provocada diretamente pelo programa. As avaliações de impacto procuram comparar as respostas dadas por dois ou mais grupos similares da população quanto às condições de exposto e não exposto a um determinado programa.

Porém, Paes-Sousa e Vaitsman (2007) observam que do ponto de vista da melhoria da capacidade de gestão do Estado, a execução de estudos de avaliação adquire relevância quando os resultados fazem parte de sistemas de avaliação, os quais devem ser institucionalizados nas estruturas governamentais, Entretanto, esse processo depende de uma série de fatores, dos quais se destaca a decisão política de implantar um sistema de avaliação e a consequente alocação de recursos financeiros, físicos e humanos.

A educação foi uma das pioneiras em implantar sistemas de avaliação para aferir a qualidade do ensino ofertado e possibilitar o estabelecimento de novas políticas e a revisão e monitoramento de programas já implementados. A avaliação de políticas educacionais será abordada de forma mais detalhada na próxima seção. 


\section{AVALIAÇÃO EDUCACIONAL NO BRASIL - HISTÓRICO E AVALIAÇÕES EM LARGA ESCALA}

Neste capítulo, há uma retomada histórica da política de avaliação da educação e de que maneira os sistemas de análise educacionais internacionais influenciaram no desenvolvimento do sistema de avaliação brasileiro. Além disso, é demonstrado como o Sistema Nacional de Avaliação da Educação Básica se configura e de que forma seus resultados influenciam na adoção de outras políticas de análise, como da alfabetização, foco desta pesquisa.

\section{1 - SITUANDO HISTORICAMENTE A AVALIAÇÃO EDUCACIONAL}

A pesquisa e a avaliação, especialmente a de programas, projetos e produtos tem significado especial no delineamento do processo decisório em educação, principalmente a partir do século XX. (VIANNA, 2005).

Adotando-se uma perspectiva histórica acerca da avaliação educacional, verifica-se a grande influência dos Estados Unidos e da Inglaterra no campo de conhecimento, do qual se originaram numerosos trabalhos que contribuíram para a exploração da análise educacional em todo o mundo.

Nos Estados Unidos, destaca-se o estudo de Ralph W. Tyler, desenvolvido entre os anos de 1930 a 1945, que procurou conceituar como “[...] um conjunto de experiências educacionais diversificadas deveriam ser planejadas para que os alunos realizassem determinados objetivos" (VIANNA, 2005, p. 148). Em sua proposta, a avaliação de aprendizagem deveria integrar o modelo de currículo e este seria o condutor das atividades educativas. Os estudos de Tyler foram disseminados em todo o mundo e sofreram algumas críticas, pois as análises estariam condicionando os currículos e fazendo com que as escolas e professores perdessem sua autonomia para definir conteúdos e abordagens adequadas ao contexto dos alunos. (HORTA NETO, 2006).

Porém, é na década de 1960 que a avaliação vive o seu momento mais intenso. O contexto político apontava para uma grande preocupação com os reflexos das desigualdades sociais na diferenciação das oportunidades educacionais. Surge, então, por influência de Robert Kennedy, o conceito de responsabilidade em educação accountability, a fim de se evitar desperdícios de recursos financeiros empenhados em programas curriculares 
e em avaliações. Com a aprovação da lei de educação elementar e secundária - Elementary and Secondary Education Act, em 1965, a avaliação, que já era prática constante, passa a ser uma imposição legal a todos os projetos financiados. (VIANNA, 2005, p. 151). Foi a partir de 1970 que a avaliação no contexto norte americano passou a se "especializar" e com isso surgiram novos estudos que associaram a avaliação às políticas públicas e ao planejamento.

$\mathrm{Na}$ Inglaterra, a avaliação educacional surge para integrar um programa social com vistas à eficiência nacional, e os estudos contribuíram para o desenvolvimento da tecnologia da Psicometria, com a construção de instrumentos de medidas psicológicas e do rendimento escolar (VIANNA, 2005).

A relação entre avaliação e qualidade ganha destaque no cenário internacional em 1965, com o primeiro grande levantamento educacional de grande alcance promovido pelo governo norte americano. No Brasil, as primeiras iniciativas para o uso de avaliação em larga escala ocorreram por inciativa da Coordenação de Aperfeiçoamento de Pessoal de Ensino Superior - Capes, com o objetivo de zelar pela qualidade do corpo docente das instituições de Educação Superior.

Nos anos 1960 e 1970, algumas instituições iniciaram processos e estudos acerca da avaliação educacional e foi realizado o incentivo à formação mais aprofundada dos profissionais na área de análise de rendimento escolar. Uma das instituições pioneiras foi a Fundação Getúlio Vargas, que criou o Centro de Estudos de Testes e Pesquisas Psicológicas - CETPP e implementou um importante programa de avaliação no Rio de Janeiro onde se desenvolveram instrumentos compostos por provas objetivas para verificar a aprendizagem de alunos, para as últimas séries do ensino médio. (GATTI, 2002).

Em meados dos anos 1970, pela iniciativa do Programa de Estudos Conjuntos de Integração Econômica Latino-Americana - ECIEL -, desenvolveu um robusto estudo avaliativo sobre os determinantes dos níveis de escolaridade e do rendimento escolar obtidos por alunos com diferentes características pessoais e socioeconômicas. Aos alunos, foi aplicado questionário para levantamento de dados sobre a situação socioeconômica, atitudes relacionadas com o processo escolar e aspirações, bem como um exame de compreensão de leitura e ciências. Foram coletados dados de diretores, professores e escolas. Este estudo foi realizado simultaneamente em vários países da América Latina e seus resultados amplamente discutidos. (GATTI, 2002).

O desenvolvimento de sistemas nacionais de avaliação, que tiveram início nos Estados Unidos, se expandiram para a Europa, Ásia e Oceania nas décadas de 1970 e 1980 (HORTA 
NETO, 2006). A partir dos anos 80, a crescente preocupação dos organismos internacionais com a questão da qualidade do ensino e a implantação de sistemas de avaliação em larga escala em diversos países latino-americanos criaram condições para que o tema adquirisse maior visibilidade no Brasil. (COTTA, 2001, p. 90). Segundo Gatti (2001) estudos desenvolvidos entre os anos de 1978 e 1982 se propuseram a analisar a Política Nacional de Educação, abrindo novas possibilidades de verificação, diferentes das análises de desempenho.

A necessidade de enfrentar novos padrões de produtividade e competitividade impostos pelo avanço tecnológico levaram à redescoberta da educação como componente essencial das estratégias de desenvolvimento e diferentes países passaram a promover reformas em seus sistemas educacionais com a finalidade de torná-los mais eficientes e equitativos. (MELLO, 1992).

O contexto de avaliação das políticas educacionais passa a envolver a atmosfera da administração pública e compor a agenda mundial na observância da eficiência na utilização dos recursos públicos, eficácia no atendimento aos anseios da democracia e efetividade nas ações implementadas pelo governo. Segundo Dalben (2002):

A década de oitenta no Brasil convive com essas discussões, associada aos debates intensos sobre os processos de democratização do ensino e da educação. Observa-se que, ao mesmo tempo em que um paradigma de diálogo entre os povos na construção de uma perspectiva inclusiva e de direitos vai sendo delineado a partir da realidade emergente, o antigo paradigma tecnicista se reafirma com bases na seletividade, na produtividade e no interesse individual inteiramente contraditório ao outro. Estes confrontos vão estar presentes na elaboração da Constituição de 1988 e vão dar origem aos movimentos e políticas do Governo Federal a partir de então. (p.7)

Como destacam Ferrer e Arregui apud Castro (2009, p. 6), esta convergência em torno das avaliações "estandarizadas" é derivada de visões, perspectivas e interesses distintos quanto ao papel dos sistemas educativos.

Durante a década de 1980, uma experiência que pode ser considerada um marco na história de desenvolvimento de estudos sobre avaliação de programas, envolvendo não só o rendimento escolar, mas também outros fatores foi a do Projeto Edurural, que se desenvolvia em todos os estados do Nordeste brasileiro. (GATTI, 2001). A autora, descreve o componente de avaliação do projeto:

A avaliação acompanhou a implementação e o desenvolvimento do projeto, sob vários aspectos, de 1982 a 1986. Analisaram-se as formas de gerenciamento geral desse projeto - sistema de monitorias, professores, organizações municipais de ensino, alunos e famílias - e, amostralmente, o local. Desenvolveram-se testes para avaliar crianças de $2^{\mathrm{a}}$ e $4^{\mathrm{a}}$ séries, considerando sua pertinência: zona rural em 
classes, geralmente, multisseriadas. Os testes foram elaborados a partir de amostras de exercícios e trabalhos colhidos nas escolas dos três estados onde a avaliação se desenvolvia - Piauí, Ceará e Pernambuco. Para isso, coletou-se material de alunos, trabalhou-se com o pessoal da região e, depois, deu-se forma final às provas. O que se tentava era construir um conjunto de testes tanto quanto possível adequado àquela realidade, buscando conferir maior validade aos dados de rendimento (GATTI, 2001, p. 23)

No fim dos anos 1980, no Ministério da Educação, discutia-se sobre vários problemas que ocorriam nos sistemas educacionais apontados pelos pesquisadores da área de educação. No centro da discussão, estava o fracasso escolar brutal que se constatava pelas estatísticas e estudos no interior das escolas. Uma das questões levantadas é que não se possuíam dados sobre o rendimento escolar dos alunos quanto aos sistemas e fatores a ele associados. (GATTI, 2001)

Aventava-se a possibilidade de que, com a mudança da Constituição, pudesse haver uma nova estrutura governamental, o que sinalizava a necessidade de uma mudança nas diretrizes oficiais em relação aos ensinos fundamental e médio. Isso levou o Ministério da Educação a intervir menos diretamente nestes níveis e a propiciar orientações e subsídios técnicos, assumindo um papel avaliador como referência para a gestão da educação básica. (GATTI, 2001)

Em um momento em que se redefinem as formas de atuação do Estado, são adotadas medidas que visam à descentralização de responsabilidades e a subsequente avaliação das ações e decisões institucionais relativas à implementação das políticas educativas. (AFONSO, 2007). A descentralização promovida pelas reformas educacionais, por meio da transferência de competências e recursos para instâncias intermediárias, levou o Governo Federal a adotar mecanismos mais flexíveis de controle, voltados para os produtos do sistema educacional e não para seus processos. (COTTA, 2001, p. 90)

Para Mello (1992), uma vez consensuados os objetivos e prioridades nacionais, era essencial que o processo de descentralização estabelecesse um sistema racional de cooperação entre a União, estados e municípios a fim de permitir a distribuição justa e o uso mais racional dos recursos, evitando a duplicidade ou sobreposição de ações. Dessa forma o autor defende que:

É indispensável que instâncias intermediárias - governadores, secretários estaduais e municipais de educação e prefeitos - estabeleçam pactos quanto aos critérios para a sistemática de financiamento e para a divisão dos encargos e funções de cada esfera de governo, e sejam responsáveis por aqueles que lhes couberem, devendo existir mecanismos eficazes de cobrança e prestação de contas das responsabilidades de cada esfera governamental (MELLO, 1992, p. 32 e 33)

Apesar de iniciativas anteriores, a avaliação de políticas, programas e projetos sociais 
e educacionais foi incorporada, de fato, à agenda governamental no início dos anos de 1990 (RUS PEREZ, 2010). Um dos fatores que contribuíram para isso foi o financiamento dos organismos multilaterais a projetos educativos para países em desenvolvimento, que passaram a vincular o conceito de qualidade à medição (GOMES NETO; ROSENBERG, 1995). O mesmo é apontado nos documentos da Comissão Econômica para América Latina e Caribe - Cepal, que, ao abordarem a questão da qualidade da educação enfatizam a necessidade do desenvolvimento de ferramentas e diagnósticos por meio de provas ou outros instrumentos de aferição da qualidade (DOURADO; OLIVEIRA; SANTOS, 2007).

Assim, para avaliar a educação básica, mais precisamente o ensino fundamental, teve início, em 1988, à implantação do Sistema Nacional de Avaliação da Educação Básica (SAEB), que tem por objetivo avaliar a qualidade do ensino oferecido pelo sistema educacional brasileiro a partir de testes padronizados e questionários socioeconômicos. $\mathrm{O}$ SAEB é uma avaliação em larga escala, amostral e realizada a cada dois anos. Desde sua criação, passou por ciclos e sofreu alterações em sua metodologia e formas de operacionalização, com foco na realização de um diagnóstico do sistema educacional brasileiro e em fatores que interferem no desempenho dos alunos, fornecendo um indicativo da qualidade do ensino ofertado.

Já em 1990, quando o SAEB ainda se chamava Sistema de Avaliação do Ensino Público de $1^{\circ}$ Grau (SAEP), a ideia era desencadear um processo de avaliação por meio de levantamentos periódicos de dados, visando captar a evolução do quadro educacional brasileiro. Ferrer apud Faria e Filgueiras (2003, p. 16) consideram que, mesmo havendo registros de experiências pioneiras de avaliação do logro educacional antes do ano de 1988, quando foram estruturados os sistemas de avaliação da educação básica chileno (Simce), após algumas experiências prévias, e o brasileiro (SAEB), este deve ser considerado “[...] el verdadero punto de arranque de la nueva tendencia". (p. 16)

Para Castro (2009) a realização de avaliações em larga escala, como forma de conhecer melhor a dinâmica dos processos e resultados dos sistemas educacionais, tem se tornado uma constante em países de diferentes culturas e distintas orientações ideológicas de governo. Além disso, verifica-se crescente tendência ao desenvolvimento de sistemas subnacionais em todo o mundo, como ocorre no Brasil. Dessa forma, completa: “[...] a institucionalização da avaliação educacional no Brasil é hoje, sem dúvida, instrumento fundamental do processo de prestação de contas à sociedade e de enriquecimento do debate público sobre os desafios da educação no país” (CASTRO, 2009, p. 6). 
Isso pode ser verificado em um estudo de Ferrer (2006), o qual descreve os casos de Avaliação da Aprendizagem na América Latina e caracteriza 19 sistemas nacionais, além de outros 4, entre eles os programas de avaliação de Minas Gerais, Paraná, São Paulo e Bogotá na Colômbia, sintetizados, posteriormente, por Horta Neto (2006), conforme Figura 1, abaixo:

Figura 1 - Sistemas de Avaliação de Aprendizagem na América Latina

Quadro 1: Sistemas de avaliação de aprendizagens na América Latina

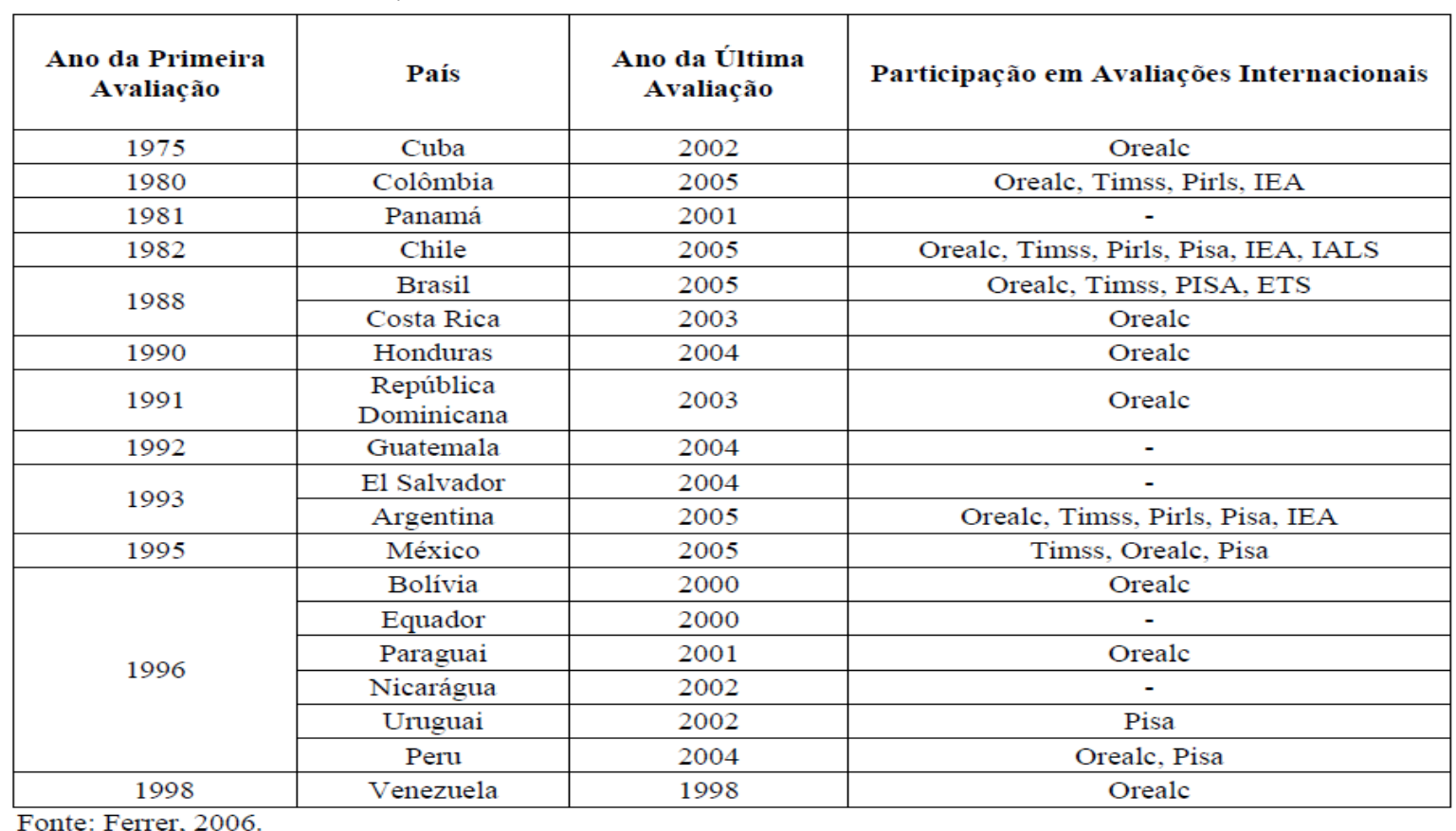

Fonte: Horta Neto (2006)

\subsection{CARACTERIZANDO AS AVALIAÇÕES EM LARGA ESCALA}

Becker apud Ferrer (2006, p. 2) descreve algumas condições desejáveis para que um país tenha um sistema de avaliação. Em primeiro lugar, os propósitos das análises e o uso do material coletado devem ser previamente debatidos; os instrumentos de medição devem estar relacionados a metas e objetivos de desenvolvimento cognitivo traçados pelo país. Deve-se decidir se o objetivo é avaliar o sistema, as instituições ou os atores individualmente, para que seja escolhido o modelo de avaliação (censitária ou amostral). A forma de apresentar os resultados deve ser coerente com o objetivo das medições.

Segundo Oliveira (2011), convencionou-se considerar as avaliações externas como avaliações em larga escala, devido ao grande número de pessoas envolvidas em cada uma de 
suas etapas ${ }^{3}$, e a tendência mais complexa, apesar de se pautarem nas mesmas fontes de informação e finalidades das avaliações internas. (HORTA, 2006; OLIVEIRA, 2011). De acordo com Vianna (2005, p. 130) "um sistema de avaliação em larga escala não se improvisa, exige experiência, juntamente com uma estrutura básica de funcionamento, controle gerencial e monitoramento que garantam a natureza do produto".

Tendo em vista que avaliar é um ato político e para que seja adequadamente político, precisa se instrumentalizar no conhecimento (RABELO, 2001, p. 74). O autor apresenta em seu estudo, algumas categorias que podem ser atribuídas às avaliações em larga escala: Quanto à sua regularidade de aplicação pode ser caracterizada como contínua ou pontual. A avaliação contínua é realizada de forma regular e não se espera que a análise ocorra apenas ao final do trabalho. Já a avaliação pontual se dá apenas ao final do trabalho ou período letivo.

Com relação à possibilidade de comparação, a avaliação pode ser normativa ou criterial. A avaliação normativa possibilita a comparação entre o rendimento de um aluno com o rendimento alcançado pelos demais colegas. Já a criterial procura situar o aluno em relação ao atingimento ou não de um dado objetivo pré-fixado, indicando sobre o que o aluno sabe ou não fazer. (RABELO, 2001).

Há ainda que se classificar as avaliações em larga escala a partir de suas funções. Importante destacar que tais categorias já são consenso entre autores e estudiosos: Quanto à sua formação, a avaliação em larga escala pode ser: diagnóstica, formativa ou somativa. A análise de natureza diagnóstica, também chamada de inicial, tem como objetivo realizar um prognóstico das capacidades do aluno em relação ao novo conteúdo abordado, situar as aptidões iniciais, verificar pré-requisitos para o planejamento de ações pedagógicas. Já a avaliação somativa, normalmente é pontual, habitualmente aplicada ao final de um ciclo que tem por objetivo determinar o grau de domínio de alguns objetivos previamente estabelecidos. Além de informar, permite situar e classificar. Por fim, a avaliação formativa tem por objetivo proporcionar informações acerca do desenvolvimento de um processo de ensino e aprendizagem, integrada à ação de formação. Se propõe a fornecer informações rápidas e úteis sobre as etapas vencidas e as dificuldades encontradas. (RABELO, 2001).

Segundo Oliveira (2011), além da classificação, as avaliações em larga escala podem ter as seguintes funções:

Autoavaliação: permite conhecer qual a posição relativa entre os participantes de uma mesma avaliação; b) credenciamento: seus resultados permitem aos participantes ingressarem no mercado de trabalho ou na educação superior, como

\footnotetext{
${ }^{3}$ Ver etapas da avaliação em larga escala: i) elaboração do projeto de avaliação; ii) construção do instrumentos padronizados (testes e questionários); iii) validação estatística dos instrumentos;
} 
por exemplo, o Exame Nacional do Ensino Médio (Enem); c) o accountability: presta conta da qualidade do ensino ofertado apresentando informações aos diferentes públicos interessados nos resultados da avaliação, tais como educadores, gestores públicos e família; apoio a decisão: oferece informações sobre os resultados alcançados, possibilitando prever situações futuras e propor ações alternativas que visem a melhoria da situação detectada. (OLIVEIRA, 2011, p.141)

As avaliações em larga escala podem, ainda, ser classificadas quanto ao corte temporal podendo ser longitudinal ou transversal. A avaliação longitudinal caracteriza-se pelo acompanhamento de um mesmo grupo de estudantes ao longo de vários anos, possibilitando a identificação do progresso de aprendizagem ou o progresso escolar de cada um deles. Já a avaliação transversal faz um corte no período de escolaridade que se pretende avaliar como alunos ao final do ensino fundamental e o foco é o desempenho escolar. (RABELO, 2001).

Outro aspecto a ser considerado na avaliação em larga escala é o método utilizado para selecionar o universo de onde serão obtidos os dados. A avaliação pode ser amostral ou censitária. Na avaliação amostral, a intenção é subsidiar os órgãos decisórios sobre a evolução do sistema educacional. Por isso, é selecionada uma amostra representativa do universo a ser examinado. Na avaliação censitária, participa todo o universo analisado e a intenção é gerar informações para subsidiar as escolas em seu trabalho pedagógico e permitir que os gestores públicos conheçam a qualidade dos estabelecimentos de ensino. (OLIVEIRA, 2011, p. 142-3).

Vianna (2005) levanta uma série de aspectos que devem ser observados durante o processo de construção de um sistema de avaliação em larga escala, dentre os quais: a terceirização do serviço, o debate da metodologia entre as partes contratantes, o trabalho cooperativo entre técnicos e especialistas, que gerenciem a construção dos testes, o processamento e divulgação de resultados, além de questões de orçamento.

Além disso, como destaca Horta Neto (2006, p. 46), é necessário definir-se previamente "[...] quais questões devem ser respondidas, os usos que se farão dessa avaliação e quais serão os usuários dos resultados". A divulgação dos resultados é uma etapa crítica do programa de avaliação, dessa forma, devem ser elaborados relatórios diferentes a cada público a que se destina.

Uma política de avaliação vai muito além da realização de provas, compilação e análise dos dados, bem como a divulgação dos resultados aferidos em relatórios e outros materiais destinados às escolas. Como bem destaca Vianna (2003), as avaliações, além das características normais relacionadas a diversos tipos de validade (conteúdo, preditiva e de construto), devem ter, necessariamente, "validade consequencial". Nesse sentido, seria 
fundamental que os resultados das avaliações chegassem aos alunos, aos pais, aos educadores e a toda a comunidade educacional, não devendo ficar restritos apenas aos setores técnicos das secretarias de educação. (GIMENES et al. 2013, p. 77).

Nesse contexto, Cotta, (2001) destaca a importância da padronização de procedimentos de coleta e processamento de dados das avaliações educacionais:

\begin{abstract}
A avaliação educacional em larga escala supõe a padronização dos procedimentos de coleta e processamento dos dados. Portanto, a forma como o sistema de avaliação é implementado influencia a qualidade e a disponibilidade de informações. Falhas operacionais podem ocasionar problemas sérios como um número muito alto de respostas faltantes (missing), inviabilizando inferências sobre determinados estratos da amostra. (COTTA, 2001, p. 104-5)
\end{abstract}

Em avaliações externas como o SAEB, desenvolvidas pelo Governo Federal, as informações coletadas são sigilosas, ou seja, quando da divulgação dos resultados, alunos, professores, diretores e escolas não são identificados: "Os níveis de desempenho das disciplinas de cada aluno não são divulgados. Apenas são divulgadas as médias dos desempenhos dos alunos em cada estrato"4 (BRASIL, 2015).

Segundo Horta Neto (2013), para se aumentar a eficácia da avaliação é necessário que outras informações sejam coletadas, além dos resultados das provas, como características sociais das escolas, dos alunos, hábitos de estudos.

\title{
2.3 AS AVALIAÇÕES EM LARGA ESCALA E A QUESTÃO DA QUALIDADE
}

Com a publicação da LDB em 1996, a avaliação da educação se consolida no cenário nacional como dever da União, ganhando força em todos os níveis e modalidades de ensino, conforme prevê o artigo $9^{\circ}$ : “[...] assegurar processo nacional de avaliação do rendimento escolar no ensino fundamental, médio e superior, em colaboração com os sistemas de ensino, objetivando a definição de prioridades e a melhoria da qualidade do ensino" (BRASIL, 2010, p. 13).

Porém, a discussão sobre qualidade da educação implica o mapeamento dos diversos elementos para qualificar, avaliar e precisar a natureza, as propriedades e os atributos

${ }^{4}$ Os estratos referem-se à série, unidades da Federação, à localização da escola (capital e interior, urbano e rural), à dependência administrativa (estadual, municipal e particular) e tamanho da escola. Também não se divulga o desempenho das escolas avaliadas. 
desejáveis ao processo educativo (DOURADO; OLIVEIRA; SANTOS, 2007). São muitas e diversas as variáveis que podem ser apontadas para a construção de educação de qualidade ou de uma escola eficaz.

Elementos como ambiente escolar, infraestrutura, currículo, prática pedagógica, expectativas de aprendizagem, formação de professores e gestão se inter-relacionam na construção das condições de qualidade, já que a mesma é um conceito dinâmico. Portanto, a "[...] qualidade da educação deve se dar em uma perspectiva polissêmica, envolvendo as condições intra e extraescolares, bem como, os diferentes atores individuais e institucionais" (DOURADO; OLIVEIRA; SANTOS, 2007, p. 29). As várias interpretações sobre esse conceito não permitem que se formule uma definição única e consensual do que ele signifique (GOMES NETO; ROSENBERG, 1995).

Davok (2007) destaca que à qualidade em educação pode ser atribuída uma variedade de interpretações a depender da concepção que se tenha sobre o que os sistemas devem proporcionar à sociedade. Já qualidade educacional tem sido utilizada para referenciar a eficiência, a eficácia, a efetividade e a relevância do setor educacional, dos sistemas de ensino e de suas instituições, explicitando-se um juízo sobre seu valor e mérito.

Portanto, um entendimento mais preciso do que seja "qualidade em educação" é absolutamente necessário como base para orientar estudos sobre processos de avaliação da qualidade de objetos educacionais (DAVOK, 2007). Esse conceito está relacionado com o que se costuma chamar de qualidade do ensino e é neste ponto que começam as divergências, já que é necessário definir o que se entende por qualidade do ensino de forma mais operacional, que possibilite sua mensuração (GOMES NETO; ROSENBERG, 1995).

De acordo com Castro (2009), nos últimos 30 anos, o sistema educacional brasileiro sofreu uma acelerada expansão, registrando-se, um grande crescimento das matrículas em todos os níveis de ensino. Ela destaca que:

Dentre os fatores que contribuíram para impulsionar este processo, além da natural
pressão demográfica, cabe destacar a forte demanda por serviços educacionais criada
em decorrência da rápida urbanização do País e o correspondente esforço realizado
pelo Poder Público para expandir o acesso à escolaridade obrigatória. As políticas de
universalização do atendimento no ensino fundamental, implementadas em regime
de colaboração pelos três níveis de governo, produziram resultados bastante
positivos na década de 1990. (p. 10)

Nesse sentido, o país tem avançado na universalização da oferta de ensino em nível fundamental. De acordo com os dados da Pesquisa Nacional por Amostra de Domicílios PNAD, a taxa de escolarização da população entre 6 e 14 anos de idade é de 98,2\%, conforme pode se observar no Quadro 1: 
Quadro 1 - Taxa de escolarização de pessoas de 4 anos ou mais de idade

\begin{tabular}{|c|c|c|c|c|c|c|}
\hline \multirow{4}{*}{$\begin{array}{l}\text { Unidades da } \\
\text { Federação }\end{array}$} & \multicolumn{6}{|c|}{ Taxa de escolarização das pessoas de 4 anos ou mais de idade (\%) } \\
\hline & \multicolumn{6}{|c|}{ Grupos de idade } \\
\hline & \multirow{2}{*}{$\begin{array}{l}4 \text { ou } 5 \\
\text { anos }\end{array}$} & \multicolumn{2}{|c|}{6 a 14 anos } & \multirow{2}{*}{$\begin{array}{c}15 \text { a } 17 \\
\text { anos }\end{array}$} & \multirow{2}{*}{$\begin{array}{c}18 \text { a } \\
24 \\
\text { anos }\end{array}$} & \multirow{2}{*}{$\begin{array}{l}25 \text { anos } \\
\text { ou mais }\end{array}$} \\
\hline & & Total & 7 a 14 anos & & & \\
\hline \multicolumn{7}{|c|}{2009} \\
\hline Brasil & 74,8 & 97,6 & 98,0 & 85,2 & 30,3 & 5,1 \\
\hline \multicolumn{7}{|c|}{2011} \\
\hline Brasil & 77,4 & 98,2 & 98,5 & 83,7 & 28,9 & 4,5 \\
\hline
\end{tabular}

Fonte: IBGE, Diretoria de Pesquisas, Coordenação de Trabalho e Rendimento, Pesquisa Nacional por Amostra de Domicílios 2009/2011. Adaptado pela autora

CASTRO (2009, p. 7) destaca que, se do ponto de vista quantitativo, a expansão do sistema atingiu patamares bastante razoáveis, inclusive em comparação aos padrões internacionais, o mesmo não pode ser dito frente aos indicadores de qualidade e equidade. No tocante a estes aspectos, a situação atual da educação nacional ainda deixa muito a desejar, apesar dos recentes avanços dos três níveis de governo para promover a melhoria do ensino e a correção das ineficiências e iniquidades do sistema.

Segundo Araújo e Luzio (2005), não basta que as crianças e os jovens tenham acesso à escola, mas é preciso que permaneçam e que isso represente agregação efetiva de conhecimentos e habilidades fundamentais para uma melhor inserção no mundo do trabalho. Os autores apontam, ainda, que por algum tempo vigoraram teorias que consideravam a escola como um mero espaço de reprodução ideológica do "statu quo". (p. 59). Educadores acreditavam e classificavam a escola como somente reprodutora das grandes estruturas ideológicas, econômicas e culturais da elite dirigente de um país. Porém esse é um grande equívoco e a educação não pode ser considerada apenas um mecanismo de reprodução.

Nesse sentido, a educação não se limita a transmitir conhecimento elaborado e sistematizado ao longo do tempo, pois assim não teria sentido o seu proceder. $\mathrm{O}$ papel fundamental da escola é responder aos anseios e necessidades sociais, uma vez que ela pode ser definida como "o microcosmo que existe na sociedade e sofre suas influências e também atua sobre ela" (VIANA, 2005, p. 22).

De acordo com Araújo e Luzio (2005, p. 59):

Caso a educação no Brasil conseguisse ao menos ensinar aos estudantes brasileiros a ler de forma competente e a usar a linguagem matemática para resolver os problemas do cotidiano estaria contribuindo, com eficiência e efetividade, para a 
promoção da igualdade e, portanto, para o desenvolvimento da Nação.

Para tanto, devem ser definidas medidas que permitam aferir o grau de atendimento oferecido pelo sistema, através de indicadores de qualidade (GOMES NETO; ROSENBERG, 1995). Nessa perspectiva, e dependendo do desenho do sistema nacional de avaliação, as informações produzidas por ele permitirão comparar resultados entre escolas, áreas geográficas, sistemas de ensino, bem como sinalizar situações mais problemáticas, que poderão ser alvo de uma política especial. (GOMES NETO; ROSENBERG, 1995)

\subsection{AS AVALIAÇÕES DOS ENTES SUBNACIONAIS}

O Ministério da Educação, por meio do Instituto Nacional de Estudos e Pesquisas Educacionais - INEP, foi incentivado a desenvolver processos de avaliação sistêmica em âmbito federal na perspectiva de oferecer diretrizes para as políticas de educação no país. Da mesma forma alguns estados brasileiros o seguiram, implementando programas em âmbito estadual.

Paralelamente ao esforço federal em produzir pesquisas de avaliação do rendimento escolar, instituíram-se a partir da década de 1990, e mais fortemente nos anos 2000, sistemas de avaliação em diversos estados brasileiros. (HORTA NETO, 2013). De acordo com o estudo realizado por Brooke; Cunha; Faleiros (2011), 18 estados brasileiros dispunham de sistemas próprios de avaliação da educação básica.

Porém, estudos apontam para a descontinuidade de políticas educacionais nos estados, dentre elas as políticas de avaliação. A Figura 2, a seguir, apresenta uma síntese da quantidade de estados, por ano, que dispõem de testes avaliativos. De acordo com HORTA NETO (2013), a inconstância no número de estados por ano é reflexo das mudanças de governo que priorizam ou não o uso das avaliações. 
Figura 2 - Evolução de UF que contam com testes avaliativos - 1992/2012.

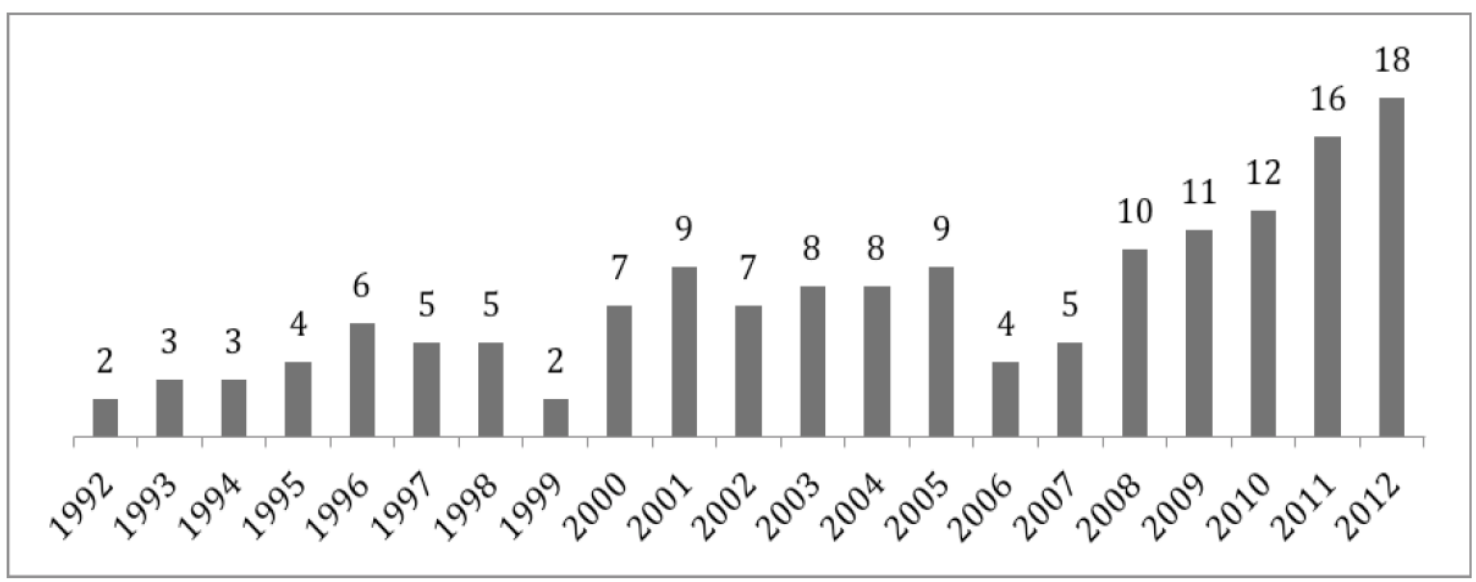

Fonte: Horta Neto - 2013 (produzido a partir de estudo de Brooke, Cunha e Faleiros, 2011)

Horta Neto (2013) sinalizou para uma expansão desse número de estados com o levantamento que revelou o resgate de sistemas de avaliação como nos Estados do Paraná e Distrito Federal, além da institucionalização do sistema de análise do Pará, conforme demonstra o Quadro 2.

Quadro 2 - Sistemas de Avaliação Estaduais

\begin{tabular}{|c|c|c|}
\hline $\mathbf{U F}$ & SISTEMA & SIGLA \\
\hline $\mathrm{AC}$ & Sistema Estadual de Avaliação da Aprendizagem Escolar & SIAPE \\
\hline AM & Sistema de Avaliação do Desenvolvimento Educacional do Amazonas & SADEAM \\
\hline $\mathrm{AL}$ & Sistema de Avaliação Educacional de Alagoas & SAVEAL \\
\hline BA & Sistema de Avaliação Baiano de Educação & SABE \\
\hline $\mathrm{CE}$ & Sistema Permanente de Avaliação da Educação Básica do Ceará & SPAECE \\
\hline $\mathrm{ES}$ & Programa de Avaliação da Educação Básica do Espírito Santo & PAEBES \\
\hline DF & Sistema de Avaliação de Desempenho Escolar & SIADE \\
\hline $\mathrm{GO}$ & Sistema de Avaliação Educacional do Estado de Goiás & SAEGO \\
\hline MA & Sistema Maranhense de Avaliação da Aprendizagem Escolar & SIMAE \\
\hline MG & Sistema Mineiro de Avaliação da Educação Pública & SIMAVE \\
\hline MS & Sistema de Avaliação da Rede Pública do Mato Grosso do Sul & SAEMS \\
\hline $\mathrm{PA}$ & Sistema Paraense de Avaliação Educacional & SISPAE \\
\hline PB & Sistema de Avaliação da Educação da Paraíba & SAEP \\
\hline $\mathrm{PE}$ & Sistema de Avaliação Educacional de Pernambuco & SAEPE \\
\hline PI & Sistema de Avaliação Educacional do Piauí & SAEPI \\
\hline PR & Sistema de Avaliação da Educação Básica do Paraná & SISPAE \\
\hline RJ & Sistema e Avaliação da Educação do Estado do Rio de Janeiro & SAERJ \\
\hline RS & Sistema Estadual de Avaliação Participativa & SEAP \\
\hline $\mathrm{RO}$ & Sistema de Avaliação Educacional de Rondônia & SAERO \\
\hline $\mathrm{SP}$ & Sistema de Avaliação do Rendimento Escolar do Estado de São Paulo & SARESP \\
\hline TO & Sistema de Avaliação da Educação do Tocantins & SALTO \\
\hline
\end{tabular}

Fonte: Elaboração própria (2015)

No caso das avaliações de ensino fundamental, apesar do grande número de estados 
que realizam avaliações externas para aferir o rendimento dos alunos, percebe-se claramente uma falta de coordenação entre os entes federados, representando, por vezes, a sobreposição de ações e o gasto desnecessário de recursos, já que tanto o ente federal, quanto o estadual e municipal, acabam avaliando a mesma coisa ou subutilizando os resultados das avaliações que poderiam servir para o planejamento de ações e políticas educacionais.

As avaliações estaduais são quase que, em sua totalidade, baseadas no modelo do SAEB. Muitas foram desenvolvidas em decorrência da necessidade de atingir os níveis estipulados pelo SAEB e posteriormente avaliados pelo IDEB. De acordo com Brooke, Cunha e Faleiros (2011, p. 7),

\begin{abstract}
“[...] a ausência de incentivos federais e de cooperação contínua entre as instâncias governamentais na área de avaliação, a não ser no empréstimo de itens do SAEB, talvez reflita a falta de uma aceitação integral pelo Ministério da importância dos sistemas de avaliação subnacionais".
\end{abstract}

Os resultados das avaliações, por vezes, revelam aspectos contrários aos objetivos dos programas avaliados e devem ser usados tanto para tomadas de decisões políticas, quanto pelos vários atores envolvidos na disputa por determinada agenda política. Portanto, é inevitável que a divulgação dos resultados das avaliações assuma uma conotação política, ainda que internamente. Já a divulgação externa de resultados sempre repercute sobre gestores, dirigentes e outros atores envolvidos nos programas avaliados (PAES-SOUSA; VAITSMAN, 2007).

$\mathrm{Na}$ próxima seção, será possível verificar a trajetória do Sistema Nacional de Avaliação da Educação Básica, composto por três avaliações em larga escala e de que forma os seus resultados influenciaram nas decisões e ações políticas que desenharam o cenário avaliativo atual. Foi a partir dos resultados do SAEB que se verificou, no Brasil, a necessidade de institucionalizar avaliações para a alfabetização que verificassem antecipadamente as condições de aprendizagem dos alunos brasileiros que seriam posteriormente submetidos às avaliações do Sistema. 


\section{DOS RESULTADOS DO SAEB AO ESTABELECIMENTO DAS AVALIAÇÕES DE ALFABETIZAÇÃO PROVINHA BRASIL E ANA}

O SAEB compõe-se de dois grandes eixos: o primeiro, voltado para o acesso ao ensino básico, no qual se verifica o atendimento à demanda (taxas de acesso e de escolarização) e a eficiência (taxas de produtividade, de transição e de eficiência interna); e o segundo, correspondente à qualidade, implica o estudo de quatro dimensões relativas:

1) ao produto - desempenho do aluno quanto à aprendizagem de conteúdos e desenvolvimento de habilidades e competências;

2) ao contexto - nível socioeconômico dos alunos, hábitos de estudo, perfil e condições de trabalho dos docentes e diretores, tipo de escola, grau de autonomia e matriz organizacional;

3) ao processo - planejamento do ensino e da escola, projeto pedagógico, utilização do tempo escolar, estratégias de ensino;

4) aos insumos - infraestrutura, espaço físico, instalações, equipamentos, recursos e materiais didáticos. (GATTI, 2001, p. 27).

CASTRO (2009) pondera que, a partir de 1995, iniciou-se o processo de construção das Escalas Comuns de Proficiência no SAEB, o que permitiu a comparação de resultados entre diferentes séries, por disciplina e de ano para ano. Com as informações obtidas, passou a ser possível monitorar as políticas voltadas para a melhoria da qualidade, da eqüidade e da eficiência do ensino básico brasileiro.

Os níveis de proficiência dos alunos em língua portuguesa podem ser verificados na figura abaixo, a qual apresenta as médias do período 1995 a 2005. Considerando a escala de proficiência do SAEB, a média dos alunos da $4^{\mathrm{a}}$ série $/ 5^{\circ}$ ano do Ensino Fundamental variou entre os níveis $2(150-175)$ e $3(175-200)$ numa escala de 10 níveis, conforme nos mostra a Figura 3. 
Figura 3 - Médias de proficiência em língua portuguesa - Brasil 1995-2005

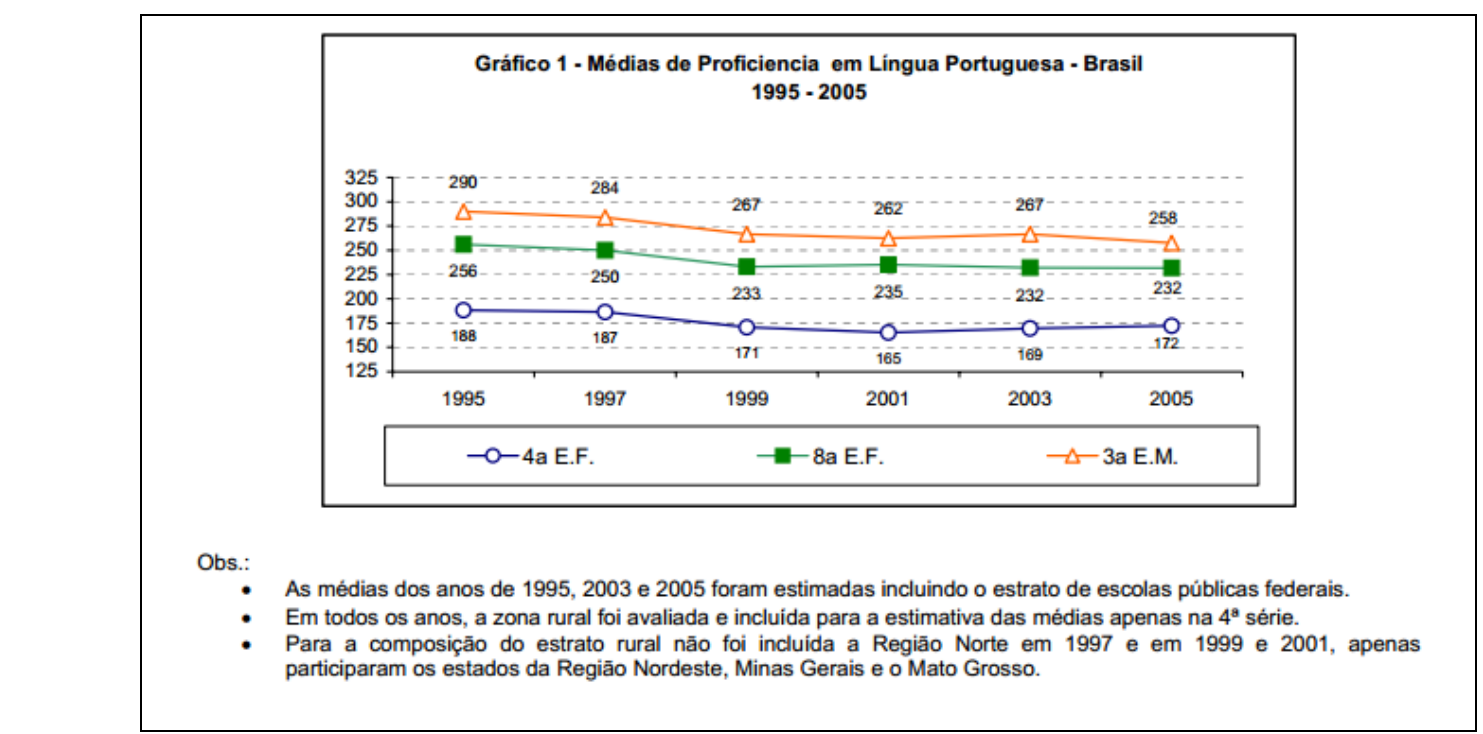

Fonte: INEP/MEC

Em 2005, ocorreu uma das principais alterações na metodologia do SAEB. Reestruturado pela Portaria Ministerial $n^{0}$ 931, de 21 de março de 2005, passou a ser composto por dois processos de análise distintos, porém complementares: Avaliação Nacional da Educação Básica (ANEB) e Avaliação Nacional do Rendimento Escolar (Anresc), conhecida como Prova Brasil, das quais as diferenças estão sintetizadas no seguinte Quadro 3, a seguir.

Quadro 3 - Avaliações que compõem o SAEB - principais diferenças

\begin{tabular}{|c|c|c|c|c|}
\hline Avaliação & Abrangência & $\begin{array}{c}\text { Dependência } \\
\text { Administrativa }\end{array}$ & Níveis de Ensino & Resultados \\
\hline Aneb & Amostral & $\begin{array}{l}\text { Rede Pública e } \\
\text { Privada }\end{array}$ & $\begin{array}{c}4^{\mathrm{a}} \text { série } / 5^{\circ} \text { ano e } 8^{\mathrm{a}} \text { série } \\
/ 9^{\circ} \text { ano do Ensino } \\
\text { Fundamental; } \\
3^{\mathrm{o}} \text { ano do Ensino Médio }\end{array}$ & $\begin{array}{l}\text { Regiões } \\
\text { geográficas e } \\
\text { Unidades da } \\
\text { Federação }\end{array}$ \\
\hline Prova Brasil & $\begin{array}{c}\text { Censitária } \\
\text { (mínimo } 20 \text { alunos } \\
\text { matriculados nas } \\
\text { séries/anos } \\
\text { avaliados) }\end{array}$ & $\begin{array}{l}\text { Redes municipal } \\
\text { estadual e federal. }\end{array}$ & $\begin{array}{c}4^{\mathrm{a}} \text { série } / 5^{\circ} \text { ano e } 8^{\mathrm{a}} \\
\text { série } / 9^{\mathrm{o}} \text { ano do Ensino } \\
\text { Fundamental }\end{array}$ & $\begin{array}{l}\text { Escolas e Ente } \\
\text { federativo }\end{array}$ \\
\hline
\end{tabular}

Fonte: Elaboração própria

A criação da Prova Brasil possibilitou fornecer informações sobre cada escola e ente federativo, tendo em vista que os resultados do SAEB, até então, eram amostrais e por Unidade da Federação. Essa mudança possibilitou o atendimento à demanda de gestores 
públicos, educadores, pesquisadores e da sociedade em geral de conhecerem os resultados de suas escolas:

O objetivo da avaliação é auxiliar os governantes nas decisões e no direcionamento de recursos técnicos e financeiros, assim como a comunidade escolar, no estabelecimento de metas e na implantação de ações pedagógicas e administrativas, visando à melhoria da qualidade do ensino. (INEP, 2005)

De acordo com o Instituto Nacional de Estudos e Pesquisas Educacionais - INEP, responsável pela avaliação:

“[...] as informações produzidas visam subsidiar a formulação, reformulação e o monitoramento das políticas na área educacional nas esferas municipal, estadual e federal, contribuindo para a melhoria da qualidade, equidade e eficiência do ensino" (INEP, 2005)

Diversas políticas educacionais são oriundas dos resultados das avaliações aplicadas pelo SAEB. O Brasil passou a trabalhar com metas e havia, agora, um sistema. Nesse contexto, em 2007 o Ministério da Educação lançou o Plano de Desenvolvimento da Educação - PDE tendo como objetivo precípuo o empreendimento de ações nacionais visando elevar o nível da qualidade do ensino. Concomitante ao PDE, foi publicado o Decreto $\mathrm{n}^{\mathrm{o}}$ 6.094/2007, que instituiu o Plano de Metas “Compromisso Todos pela Educação”, no qual foram delineadas 28 diretrizes pautadas em resultados de avaliação de qualidade e de rendimento escolar, além de medidas de apoio e de infraestrutura.

Entre as metas lançadas, a previsão de utilização do Índice de Desenvolvimento da Educação Básica - IDEB como o indicador objetivo para a verificação do cumprimento de metas fixadas no termo de adesão ao "Compromisso Todos pela Educação". Criado em 2007, o Índice representa a iniciativa pioneira de reunir, em um só indicador, dois conceitos igualmente importantes para a qualidade da educação: o fluxo escolar e as médias de desempenho nas avaliações. Nesse sentido:

O Índice de Desenvolvimento da Educação Básica (IDEB) [...] é um indicador educacional que relaciona de forma positiva informações de rendimento escolar (aprovação) e desempenho (proficiências) em exames padronizados, como a Prova Brasil e o SAEB. Estudos e análises sobre qualidade educacional raramente combinam rendimento e desempenho, ainda que a complementaridade entre ambos os indicadores seja evidente (FERNANDES, 2007, p. 1)

O IDEB foi criado em uma escala de zero a dez e é calculado a partir dos dados sobre aprovação escolar, obtidos no Censo Escolar, e médias de desempenho nas avaliações do INEP, a ANEB e a Prova Brasil. A série histórica de resultados do IDEB se inicia em 2005, a partir da qual foram estabelecidas metas bienais de qualidade a serem atingidas não apenas 
pelo País, mas também por escolas, municípios e unidades da Federação, conforme se verifica na Figura 4.

Figura 4 - Evolução das metas do IDEB

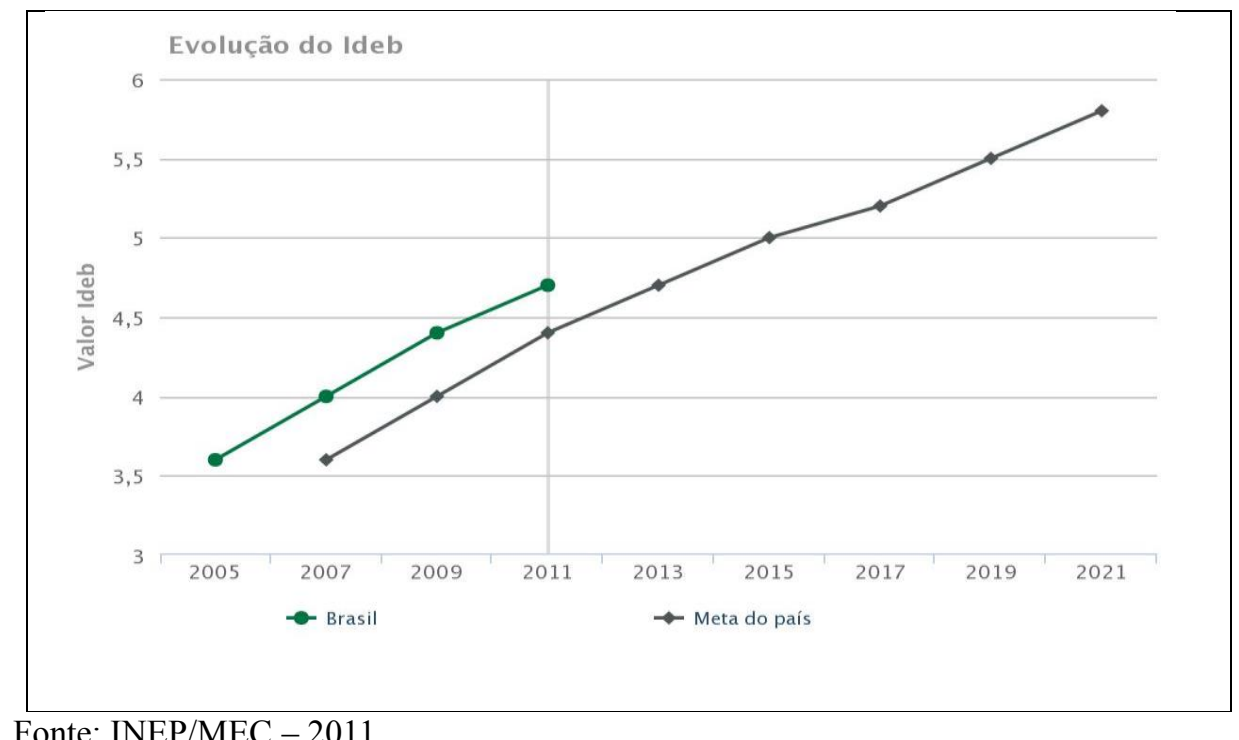

Fonte: INEP/MEC - 2011

A lógica do indicador é a de que cada instância evolua de forma a contribuir, em conjunto, para que o Brasil atinja o patamar educacional da média dos países da Organização para a Cooperação e Desenvolvimento Económico - OCDE. Em termos numéricos, isso significa progredir da média nacional 3,8, registrada em 2005 na primeira fase do ensino fundamental, para um IDEB igual a 6,0 em 2022. (FERNANDES, 2007, p. 2).

Para cada Estado, município e para cada escola brasileira, é possível definir a trajetória do IDEB que contribuirá para que o Brasil atinja a meta escolhida no prazo definido. Para o cálculo das metas intermediárias e finais, dos Estados, municípios e escolas, leva-se em consideração o IDEB inicial observado, fazendo com que cada rede obtenha uma trajetória diferente ao longo dos anos. (FERNANDES, 2007).

Os indicadores produzidos pelo SAEB desde 1990 apontaram déficits no ensino oferecido nas escolas brasileiras, refletindo os baixos níveis de desempenho dos alunos. Parte significativa desses alunos chega ao final do ensino fundamental com o domínio insuficiente de competências essenciais ao prosseguimento nos estudos. (BRASIL, 2014).

Diante dessa realidade, uma das iniciativas implementadas pelo Governo Federal diz respeito à ampliação do ensino fundamental de oito para nove anos de estudo, a iniciar-se aos seis anos de idade, pela Lei $\mathrm{n}^{\circ}$ 11.274, de 6 de fevereiro de 2006. Tal ampliação já havia sido sinalizada pela Lei $n^{0}$ 9.394, de 1996, e tornou-se meta da educação nacional pela Lei $n^{0}$ 
10.172, de 2001, com o intuito de assegurar aos alunos “[...] um tempo mais longo de convívio escolar, oportunizando mais possibilidades de aprendizagem”. (BRASIL, 2001).

Segundo Oliveira e Rocha (2007, p. 3) está nos baixos índices de habilidade em leitura revelados pelo SAEB, na meta estabelecida pelo Governo Federal de que toda criança consiga ler aos oito anos e na demanda social e historicamente constituída em torno de uma das funções precípuas da escola: o domínio da leitura e da escrita, as razões para o surgimento, mesmo que pontual, das iniciativas de verificação dos índices de alfabetização nos dois primeiros anos do ciclo e concluem que a realização de diagnósticos, em momentos iniciais da escolarização com foco na alfabetização, leitura e escrita pode levar a intervenções mais precoces e eficientes.

Na busca pela melhoria dos resultados revelados pelo SAEB e na perspectiva de atender ao Plano de Metas "Compromisso Todos pela Educação", no que tange à necessidade de alfabetizar as crianças até, no máximo, os oito anos de idade, foi instituída por meio da Portaria Normativa $\mathrm{n}^{\mathrm{o}}$ 10, de 26 de abril de 2007, a Avaliação da Alfabetização - Provinha Brasil, com o objetivo de avaliar o nível de alfabetização dos educandos nos anos iniciais do ensino fundamental.

Trata-se de um instrumento de avaliação aplicado, no início e no término do ano letivo, com a finalidade de auxiliar professores e gestores a monitorarem os processos de desenvolvimento da alfabetização oferecida nas escolas públicas brasileiras. Importante destacar que a aplicação da Provinha Brasil é opcional e fica a critério de cada Secretaria de Educação.

Dessa forma, a Provinha Brasil é instituída com a finalidade de: i) avaliar o nível de alfabetização dos educandos nos anos iniciais do ensino fundamental; ii) oferecer às redes de ensino um resultado da qualidade da alfabetização, prevenindo, assim, o diagnóstico tardio dos déficits de letramento; e iii) concorrer para a melhoria da qualidade do ensino e para a redução das desigualdades, em consonância com as metas e políticas estabelecidas pelas diretrizes da educação nacional. (BRASIL, 2007)

A Provinha Brasil não faz parte do escopo do SAEB, mas significou para os municípios a oportunidade da aplicação, pelas escolas, de uma matriz de referência externa, que possibilita o diagnóstico sobre o nível de alfabetização dos alunos e o planejamento de ações específicas para a reversão de resultados negativos. As informações coletadas permitem às Secretarias de Educação a revisão dos planejamentos e estabelecimento de metas pedagógicas, além da adequação das estratégias de ensino e adoção de políticas pertinentes à 
realidade de cada rede e escola.

\subsection{PROVINHA BRASIL: AVALIAÇÃO DIAGNÓSTICA DA ALFABETIZAÇÃO}

Assim, desde 2008 a Provinha Brasil, com foco nas habilidades de língua portuguesa, vem sendo disponibilizada em dois períodos: no início e no término do ano letivo. Os dados e as informações que podem ser coletadas permitem às Secretarias de Educação a revisão dos planejamentos e o estabelecimento de metas pedagógicas, a escolha dos componentes curriculares que precisam ser enfatizados, a adequação das estratégias de ensino de acordo com as necessidades dos alunos e, ainda, a adoção de medidas políticas pertinentes às realidades de cada escola ou rede.

Com uma proposta similar, ampliou-se, a partir de 2011, o entendimento da avaliação da alfabetização, incluindo instrumentos para monitoramento das habilidades de matemática. O intuito foi garantir que fosse realizado o diagnóstico do processo de alfabetização de uma maneira ampla e, ao mesmo tempo, que se permitisse o desenvolvimento de atividades e a reorganização da prática pedagógica dessa área de conhecimento.

Para operacionalizar a aplicação da Provinha Brasil nos estados, o INEP disponibiliza às Secretarias Estaduais de Educação, o kit da Provinha Brasil composto, atualmente, por três documentos: Guia de Aplicação; Caderno do Aluno; Guia de Correção e Interpretação dos Resultados. Importante ressaltar que os professores e a equipe escolar precisam conhecer todos os documentos que compõem o kit para compreender a metodologia da avaliação, bem como seus objetivos. O conjunto de instrumentos de avaliação que compõem o kit da Provinha Brasil é disponibilizado exclusivamente aos gestores das redes, que ficam responsáveis pelas definições sobre as formas de aplicação e correção dos testes, assim como pelas análises dos resultados.

A primeira edição da Provinha Brasil tem como principal objetivo realizar o diagnóstico dos níveis de alfabetização dos alunos após um ano de estudos, de maneira que as informações resultantes possam orientar o trabalho do professor e dos gestores ao longo do ano. A segunda edição, realizada no final do ano letivo, tem por objetivo possibilitar uma comparação com os resultados obtidos no primeiro momento da avaliação (BRASIL, 2014).

Assim, compreende-se que a participação nessa avaliação traz benefícios para todos os envolvidos no processo educativo - alunos, professores alfabetizadores e gestores. O Inep elenca, em seus relatórios, alguns desses benefícios: 
a) Os alunos poderão ter suas necessidades mais bem atendidas mediante o diagnóstico realizado e, com isso, espera-se que o seu processo de alfabetização aconteça satisfatoriamente;

b) Os professores alfabetizadores contarão com um instrumental valioso - que possibilitará a reorientação sobre o que ensinar e como ensinar — para identificar, de forma sistemática, as dificuldades dos alunos. Além disso, as análises e interpretações dos resultados e os documentos pedagógicos a eles relacionados poderão contribuir para a formação dos professores;

c) Os gestores poderão fazer escolhas bem fundamentadas em sua gestão, reunindo elementos para o planejamento curricular e para subsidiar a formação continuada dos professores alfabetizadores, a fim de melhorar a qualidade do ensino em sua rede. (BRASIL, 2014)

$\mathrm{Na}$ Provinha Brasil, assim como em outros instrumentos que permitem avaliações padronizadas, é produzida uma medida quantitativa que possui um significado qualitativo. O valor numérico é usado para quantificar ou operacionalizar um conceito abstrato, no caso, os níveis de alfabetização e letramento em língua portuguesa e matemática dos alunos que estão iniciando ou terminando o segundo ano de escolarização. Cada questão que compõe os testes da Provinha Brasil foi previamente aplicada a diferentes grupos de alunos de todo o país. Após essa ação, denominada pré-teste, as respostas dos alunos foram analisadas conforme critérios estatísticos e pedagógicos, identificando, assim, que habilidades as questões medem efetivamente; se são fáceis, médias ou difíceis, e se estão adequadamente escritas e ilustradas, entre outros aspectos.

Na Provinha Brasil, são avaliadas habilidades relativas à alfabetização e ao letramento iniciais. Nem todas as habilidades a serem desenvolvidas durante o processo de alfabetização são passíveis de verificação por meio dessa avaliação, considerando as características específicas desse teste e da metodologia utilizada (duração, questões de múltipla escolha, reduzido número de questões para não tornar o teste muito extenso, controle da mediação do professor/aplicador, entre outros aspectos). Portanto, é necessário selecionar, para cada edição, um número de habilidades da Matriz de Referência para Avaliação da Alfabetização e do Letramento Inicial e da Matriz de Referência para a Avaliação da Alfabetização matemática Inicial para construir o teste. Ressalta-se que as matrizes de referência da Provinha Brasil serão posteriormente analisadas na pesquisa. 
O teste que cada aluno receberá é composto por: uma questão-exemplo, para orientar os alunos sobre como deverão responder ao teste; 20 questões de múltipla escolha, com quatro alternativas cada. Na metodologia de aplicação da Provinha Brasil, há três possibilidades de mediação do professor ou do aplicador designado para a realização da avaliação. Há três tipos de enunciado das questões:

a) Tipo 1 - Totalmente lidas pelo professor/aplicador: questões cujos enunciados e alternativas devem ser totalmente lidos.

b) Tipo 2 - Parcialmente lidas pelo professor/aplicador: questões nas quais serão lidos apenas os enunciados ou um deles, ou, ainda, o texto para acompanhamento pelos alunos.

c) Tipo 3 - Lidas pelos alunos individualmente: questões em que o professor/aplicador deverá apenas orientar aos alunos que leiam sozinhos os textos, os enunciados e as alternativas.

A seguir, as figuras 5 e 6 exemplificam questões da Provinha Brasil que devem ser mediadas por professores:

Figura 5 - Exemplo de questão de língua portuguesa que deve ter o enunciado lido pelo professor/aplicador responsável pela aplicação

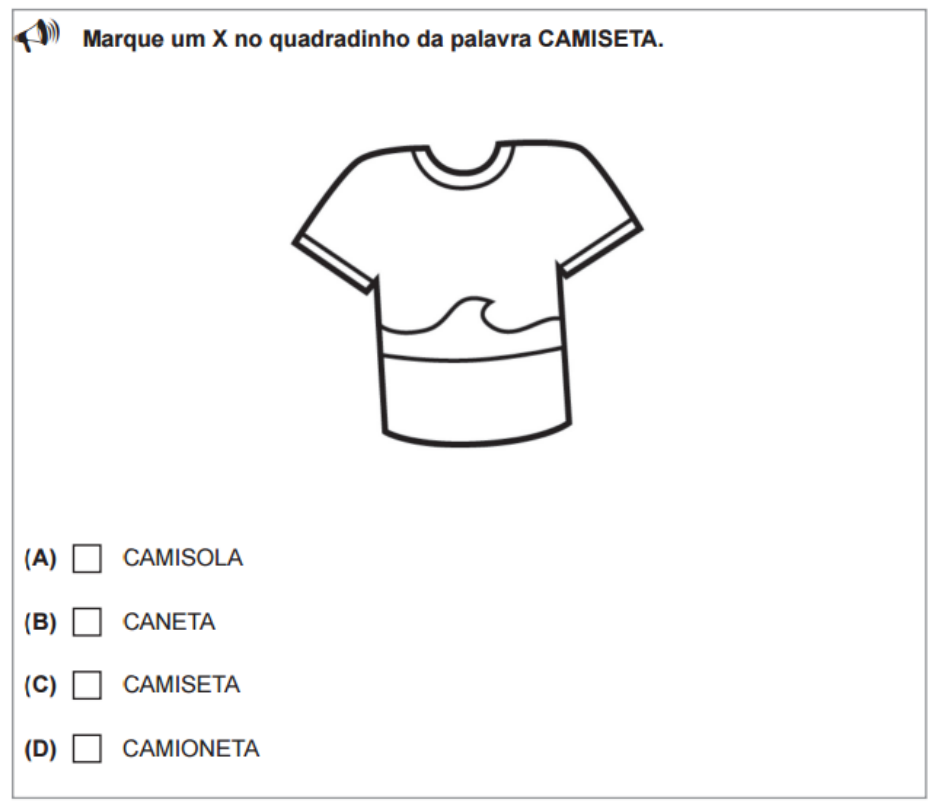

Fonte: INEP ( 2014) 
Figura 6 - Exemplo de questão de matemática. O professor/aplicador deve ler apenas o enunciado e não deve realizar a leitura das alternativas.

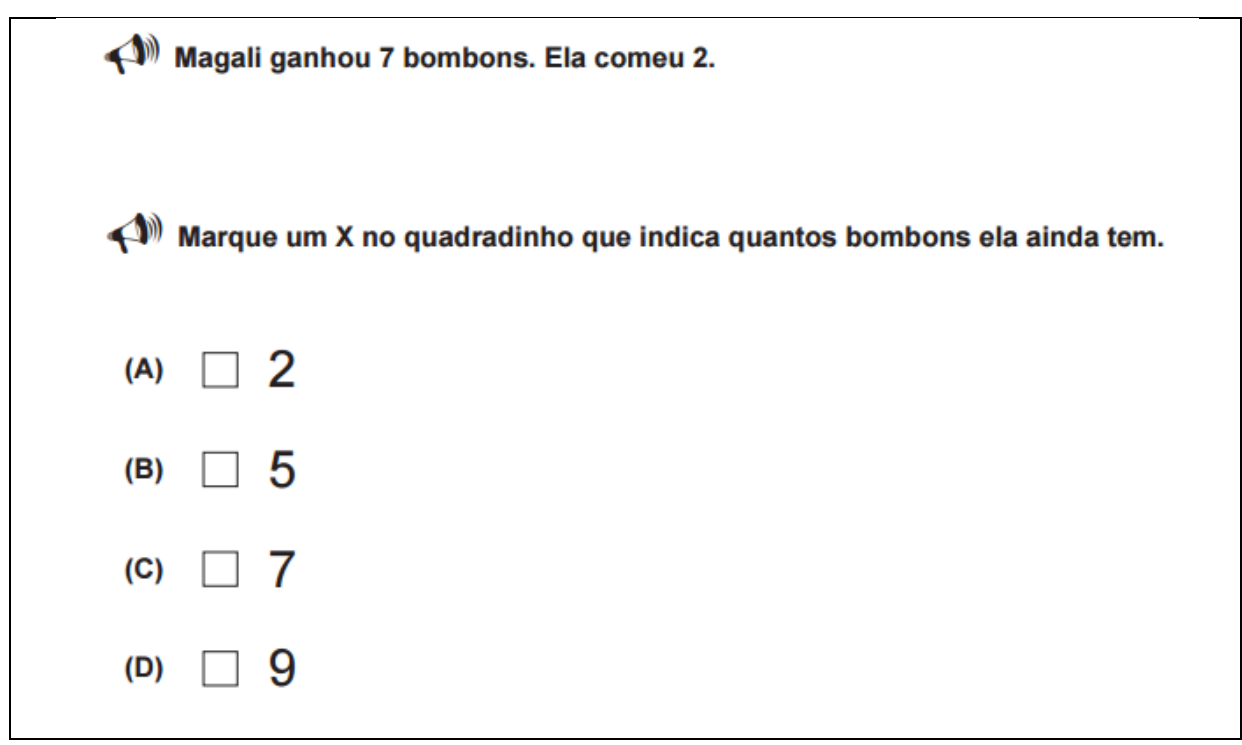

Fonte: INEP (2014).

Tendo em vista as contribuições que a avaliação pode trazer para a organização do trabalho docente, vale reafirmar que os professores e gestores, com base nos resultados da avaliação, devem refletir sobre a prática pedagógica desenvolvida na escola. O objetivo dessa reflexão é redefinir o planejamento de ensino e aprendizagem, modificando-o, especificandoo, aprimorando-o.

Isso significa considerar que os resultados da Provinha Brasil podem redimensionar objetivos e metas do trabalho pedagógico que será desenvolvido nos anos iniciais do ensino fundamental. Isso significa, ainda, que os profissionais das escolas precisam estar comprometidos com a análise coletiva dos resultados da avaliação, procurando investigar e compreender a natureza dos erros e acertos dos alunos. Só assim a discussão desses resultados levará à tomada de decisões quanto ao trabalho a ser desenvolvido durante o ano letivo.

Os resultados da aplicação da Provinha Brasil devem ser registrados em fichas de correção, como na Figura 7, onde é possível colocar as respostas dadas por cada um dos alunos (num total de 35). O preenchimento da ficha permitirá a visualização do número de acertos de cada aluno e a média da turma. 
Figura 7 - Exemplo de ficha de correção da Provinha Brasil

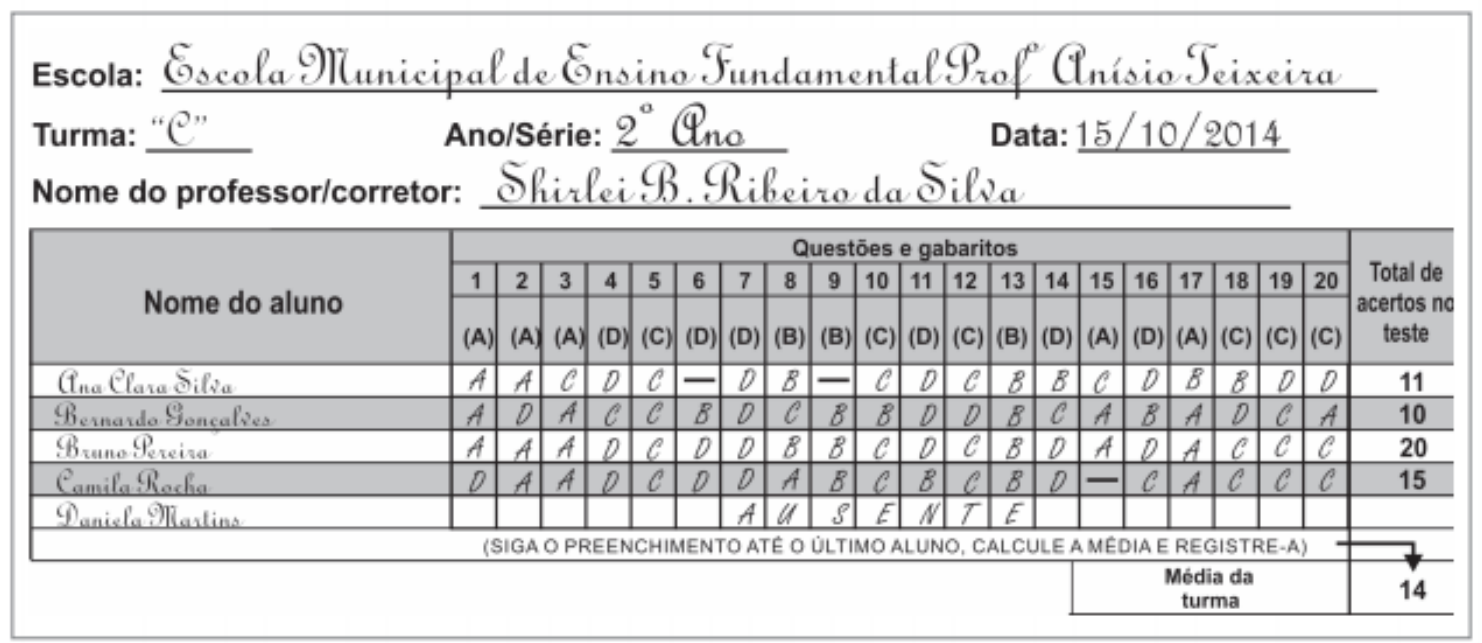

Fonte: INEP (2014).

Apesar de a ficha ser encaminhada no Kit da Provinha Brasil, o INEP alerta pela possibilidade de utilização de outros modelos adaptados à realidade de cada escola ou rede de ensino: "Há autonomia para se criar outro modelo, constando essas e/ou outras informações que melhor se adaptem às necessidades de cada realidade" (INEP, 2014)

As respostas dos alunos podem ser interpretadas estabelecendo-se uma relação entre o número ou a média de acertos de um ou mais alunos e sua correspondência com níveis de desempenho descritos para a Provinha Brasil de Leitura e de matemática. Dessa forma, quando consegue responder corretamente a um quantitativo de questões do teste, o aluno demonstra ter desenvolvido determinadas habilidades.

Para constituir os níveis, foi feita uma análise do grau de dificuldade das habilidades medidas no instrumento do Pré-teste. Em seguida, as habilidades foram distribuídas gradativamente e associadas aos processos cognitivos e conhecimentos, desde os mais básicos até os mais complexos. Em função do número de questões de múltipla escolha respondidas corretamente, foram definidos e descritos cinco níveis de alfabetização e letramento inicial em língua portuguesa e também cinco níveis de alfabetização em matemática em que os alunos podem estar situados.

Cabe ressaltar, ainda, que a interpretação das respostas dos alunos não pode ser feita com base no erro ou no acerto de uma questão isolada, pois o acerto ou o erro de uma única questão é definido por uma série de fatores circunstanciais. Apenas um conjunto de acertos pode garantir uma descrição segura do desempenho do aluno. Quando o aluno consegue responder corretamente a questões de múltipla escolha, demonstra já ter desenvolvido 
determinadas habilidades. Assim, as respostas dos alunos ao teste podem ser interpretadas estabelecendo-se uma relação entre o número ou a média de acertos de um ou mais alunos e sua correspondência com níveis de desempenho descritos para a Provinha Brasil de língua portuguesa (Vide Quadro 4).

Quadro 4 - Níveis da escala de proficiência da Provinha Brasil 2014

\begin{tabular}{cccc}
\hline & \multicolumn{2}{c}{ Teste 1 } & Teste 2 \\
\hline Nível 1 & até 5 acertos & Nível 1 & até 3 acertos \\
Nível 2 & De 6 a 10 acertos & Nível 2 & De 4 a 7 acertos \\
Nível 3 & De 11 a 15 acertos & Nível 3 & De 8 a 12 acertos \\
Nível 4 & De 16 a 17 acertos & Nível 4 & De 13 a 15 acertos \\
Nível 5 & De 18 a 20 acertos & Nível 5 & De 16 a 20 acertos \\
\hline
\end{tabular}

Fonte - INEP (2014) - adaptado pela autora

Nesse sentido, Pipolo e Medeiros (2010) destacam que a Provinha Brasil atende às características de uma avaliação externa na medida em que seus instrumentos são elaborados por agentes externos, a partir de uma matriz de habilidades consideradas essenciais para a alfabetização e letramento e com uma aplicação sistemática - no início e no final do ano letivo. Porém a metodologia de aplicação, correção e análise dos resultados descaracterizamna como avaliação externa, pois ficam sob responsabilidade das escolas sem um controle realizado pelo Ministério da Educação.

Assim, colocam uma questão importante sobre a contribuição da Provinha Brasil na busca pelo alcance das metas do Compromisso Todos pela Educação:

\footnotetext{
"Como pode ser considerada como um instrumento periódico específico, necessário para aferir o desempenho da alfabetização, se a sua aplicação e correção ocorrem de forma diferenciada em estados e municípios, sem a coordenação e controle de agentes externos e se os seus resultados não são obrigatoriamente divulgados?" (Pipolo e Medeiros, 2010, p.95).
}

Apesar da Provinha Brasil contribuir para o processo de avaliação da qualidade da escolarização das séries iniciais nas redes e escolas, que devem a partir de então empreender ações específicas para o avanço na qualidade do ensino, sua metodologia não permite que se revele um diagnóstico da realidade da alfabetização no Brasil. Seus resultados não são necessariamente divulgados e não podem ser generalizados, tampouco comparados. 
Para Pipolo e Medeiros (2010), é preciso aprimorar a metodologia da Provinha Brasil para que ela cumpra melhor seu papel de avaliação padronizada, em larga escala, e possa auxiliar o monitoramento e a avaliação dos processos e resultados da alfabetização oferecida nas escolas públicas brasileiras, contribuindo para a obtenção de informações confiáveis sobre o nível de alfabetização dos alunos do segundo ano de escolarização.

Em 2014, o guia de correção trouxe a inovação do Sistema da Provinha Brasil, desenvolvido pelo INEP para auxiliar as escolas e redes a visualizarem os resultados da avaliação a partir de relatórios eletrônicos:

O Sistema funciona como ferramenta oferecida pelo INEP às escolas e redes de ensino que desejem visualizar os resultados da Provinha Brasil em forma de relatórios eletrônicos. Dessa forma, o referido Sistema pretende apoiar as escolas e redes de ensino na análise dos dados produzidos a partir da aplicação da Provinha Brasil. (BRASIL, 2014, p.24)

Porém, essa proposta, apesar de anunciada às escolas e Secretarias Estaduais e Municipais de Educação, não se concretizou. O que facilitou a interpretação dos dados por professores foi a inclusão de comentários a respeito de cada questão avaliada. No entanto, ainda é preciso construir mecanismos que garantam o retorno dos resultados da Provinha Brasil, assegurando que ela contribua para a construção de uma política pública de formação continuada para o professor alfabetizador.

\subsection{AVALIAÇÃO NACIONAL DA ALFABETIZAÇÃO}

Se não pelos resultados da Provinha Brasil, de acordo com o Ministério da Educação, o Censo do IBGE, em 2010, revelou que a média nacional de crianças não alfabetizadas até os oito anos de idade chega a 15,2\%. A pergunta realizada na pesquisa foi "A criança sabe ler e escrever?". Os resultados encontram-se detalhados na Figura 8, abaixo 
Figura 8: Crianças não alfabetizadas aos oito anos por Região

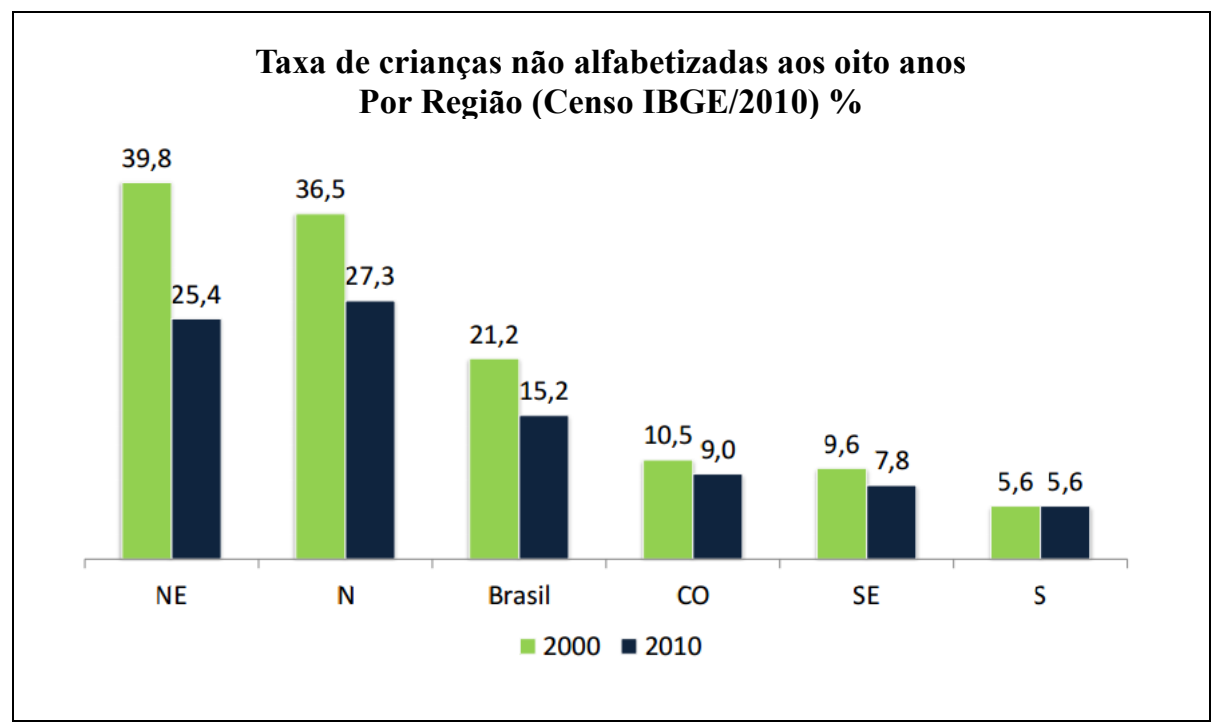

Fonte: MEC

Se comparada por regiões, essa taxa é ainda mais elevada no Norte $(27,3 \%)$ e no Nordeste $(25,4 \%)$, evidenciando a necessidade de desenvolvimento de ações que tornem o processo de alfabetização mais eficiente e universal.

Diante desse cenário e considerando o atendimento à meta de alfabetizar todas as crianças de oito anos, nas 27 unidades da federação, sem exceção, estava posto o grande desafio do Governo Federal. Com vistas ao cumprimento da meta, foi lançado pela Portaria $n^{\circ}$ 867, de 4 de julho de 2012, o Pacto Nacional pela Alfabetização na Idade Certa.

O Pacto constitui-se em um compromisso formal assumido pelos governos Federal, do Distrito Federal, dos estados e municípios para assegurar a plena alfabetização de todas as crianças até os oito anos de idade, ao final do $3^{\circ}$ ano do ensino fundamental. Ao aderirem ao Pacto, os entes governamentais assumem o compromisso de alfabetizar todas as crianças em língua portuguesa e matemática; realizar as avaliações anuais aplicadas pelo INEP, junto aos alunos concluintes do $3^{\circ}$ ano do ensino fundamental; e no caso dos estados, apoiar os municípios que aderiram ao Pacto para a sua efetiva implementação.

Com investimento inicial de $\mathrm{R}$ \$ 2,7 bilhões, o pacto foi uma articulação inédita com todos os secretários estaduais de educação e, quando de seu lançamento, teve a adesão de 5.271 municípios e seus números encontram-se detalhados na figura seguinte, o que permite uma panorâmica de sua arquitetura institucional (vide Quadro 5). 
Quadro 5 - Números do PNAIC

\begin{tabular}{cc}
\hline Informação & Quantidade \\
\hline Matrículas do $1^{\circ}, 2^{\circ}$ e $3^{\circ}$ ano & 7.980 .786 \\
Escolas com matrículas no $1^{\circ}, 2^{\circ}$ e $3^{\circ}$ ano & 108.733 \\
Turmas do $1^{\circ}, 2^{\circ}$ e $3^{\circ}$ ano & 400.069 \\
Professores Alfabetizadores do $1^{\circ}, 2^{\circ}$ e $3^{\circ}$ ano & 358.885 \\
Adesão ao Pacto - Estados & 27 \\
Adesão ao Pacto - Municípios & 5.270 \\
\hline
\end{tabular}

* Inclui turmas multisseriadas e multietapa.

Fonte: MEC/ 2012

De acordo com o artigo $5^{\circ}$ da Portaria 867 de instituição do Pacto, suas ações têm por objetivos: I - garantir que todos os estudantes dos sistemas públicos de ensino estejam alfabetizados, em língua portuguesa e em matemática, até o final do $3^{\circ}$ ano do ensino fundamental; II - reduzir a distorção idade-série na Educação Básica; III - melhorar o Índice de Desenvolvimento da Educação Básica (IDEB); IV - contribuir para o aperfeiçoamento da formação dos professores alfabetizadores; V - construir propostas para a definição dos direitos de aprendizagem e desenvolvimento das crianças nos três primeiros anos do ensino fundamental.

Como forma de operacionalização, o Pacto apoia-se em quatro eixos de atuação: i) Formação continuada presencial para os professores alfabetizadores e seus orientadores de estudo; ii) materiais didáticos, obras literárias, obras de apoio pedagógico, jogos e tecnologias educacionais; iii) avaliações sistemáticas; e Gestão, mobilização e controle social (MEC, 2012).

A Avaliação é um dos eixos estruturantes do Pacto e reúne três componentes principais:

- Avaliações processuais, debatidas durante o curso de formação, que podem ser desenvolvidas e realizadas continuamente pelo professor junto aos alunos.

- Os professores terão acesso a um sistema informatizado, onde deverão inserir os resultados da Provinha Brasil de cada criança, no início e no final do $2^{\circ}$ ano. Através deste sistema, docentes e gestores poderão acompanhar o desenvolvimento da aprendizagem de cada aluno de sua turma, e fazer os ajustes necessários para garantir que todos estejam alfabetizados no final do $3^{\circ}$ ano do ensino fundamental. 
- Ao final do $3^{\circ}$ ano, todos os alunos farão uma avaliação coordenada pelo INEP. O objetivo desta avaliação universal será avaliar o nível de alfabetização alcançado pelas crianças ao final do ciclo. Esta será mais uma maneira da rede analisar o desempenho das turmas e adotar as medidas e políticas necessárias para aperfeiçoar o que for necessário (MEC, 2012).

O Plano Nacional de Educação aprovado para o decênio 2011 a 2020 estabeleceu em sua meta 5: Alfabetizar todas as crianças até, no máximo, os oito anos de idade. O Plano traz como uma de suas estratégias a aplicação de exame periódico para aferir a alfabetização das crianças.

Diferente da Provinha Brasil aplicada no início e final do $2^{\circ}$ ano do Ensino Fundamental, de forma amostral, a Avaliação Nacional da Alfabetização - ANA é uma avaliação externa, censitária, aplicada a todos os alunos ao final do $3^{\circ}$ ano do ciclo de alfabetização, a fim de verificar o nível de alfabetização das crianças e se as demais medidas adotadas pelos governos federal, estaduais e municipais estão produzindo melhorias na qualidade do ensino e no processo de alfabetização das crianças brasileiras.

A atenção voltada ao Ciclo de Alfabetização deve-se à concepção de que esse período é considerado necessário para que seja assegurado a cada criança o direito às aprendizagens básicas da apropriação da leitura e da escrita, e também à consolidação de saberes essenciais dessa apropriação, ao desenvolvimento das diversas expressões e ao aprendizado de outros saberes fundamentais das áreas e componentes curriculares obrigatórios (INEP, 2013).

É nesse contexto de enfrentamento dos desafios educacionais postos à alfabetização das crianças que se insere a Avaliação Nacional da Alfabetização. A ANA propõe a análise do desempenho dos alunos ao final do $3^{\circ}$ ano do ensino fundamental, mas também as condições de aprendizagem desse aluno. Para tanto, prevê a aplicação de questionários aos professores e gestores educacionais que possam mapear aspectos como infraestrutura, formação docente, gestão escolar, trabalho pedagógico entre outros. 


\title{
4 MÉTODOS, PROCEDIMENTOS E TÉCNICAS DE PESQUISA
}

O presente Capítulo apresenta os procedimentos metodológicos que foram utilizados para a realização da pesquisa proposta, anunciando o seu desenho e tipificação, bem como a delimitação dos participantes, os procedimentos detalhados de coleta de dados a partir de múltiplas técnicas e a análise dos dados coletados.

\subsection{DESENHO E TIPIFICAÇÃO DA PESQUISA}

O estudo em questão terá abordagem qualitativa. Os autores Denzin e Lincoln (2005, p. 3) apresentam a seguinte definição "inicial e genérica” para esse método:

\begin{abstract}
A pesquisa qualitativa é uma atividade situada que posiciona o observador no mundo. Ela consiste em um conjunto de práticas interpretativas e materiais que tornam o mundo visível. Essas práticas transformam o mundo, fazendo dele uma série de representações, incluindo notas de campo, entrevistas, conversas, fotografias, gravações e anotações pessoais. Nesse nível, a pesquisa qualitativa envolve uma postura interpretativa e naturalística diante do mundo. Isso significa que os pesquisadores desse campo estudam as coisas em seus contextos naturais, tentando entender ou interpretar os fenômenos em termos dos sentidos e que as pessoas lhes atribuem.
\end{abstract}

Trata-se de um estudo que pode ser classificado como empírico a partir da utilização da triangulação de métodos. Merriam (1998) sugere que diferentes fontes, tais como entrevistas com indivíduos de distintos níveis hierárquicos e diferentes tipos de técnicas de coleta de dados, como entrevistas e observações sobre determinado caso, podem enriquecer sua compreensão sobre o fenômeno estudado.

As análises apresentadas poderão ser divididas em dois momentos: A primeira etapa, operacionalizada por meio de dados secundários a partir de pesquisa documental, que pode ser definida como técnica que utiliza documentos contemporâneos ou retrospectivos, considerados cientificamente autênticos. A análise documental constitui uma técnica importante na pesquisa qualitativa, seja complementando informações obtidas por outras técnicas, seja desvelando aspectos novos de um tema ou problema (LUDKE; ANDRÉ, 1986).

A segunda parte da pesquisa corresponde à coleta de dados de fonte primária, junto aos servidores especialistas do INEP, através de grupo focal e realização de entrevistas semiestruturadas junto aos interlocutores, técnicos das Secretarias Estaduais de Educação, quanto ao uso dos resultados das avaliações supracitadas em seus estados, identificados como informantes-chave. 
Segundo Morgan (1997) apud Gui (2003, p. 141) “[...] a marca registrada do grupo focal é a utilização explícita da interação grupal para produzir dados e insights que seriam menos acessíveis sem a interação produzida em grupo.” O autor destaca no grupo focal, não se busca o consenso e sim a pluralidade de ideias. Assim, a ênfase está na interação dentro do grupo, baseada em tópicos oferecidos pelo pesquisador, que assume o papel de moderador.

Já a entrevista semiestruturada tem como característica questionamentos básicos que são apoiados em teorias e hipóteses que se relacionam ao tema da pesquisa. Triviños (1987, p. 146). As perguntas realizadas pelo entrevistador podem gerar novos questionamentos e hipóteses a partir das respostas dos participantes. Nesse sentido, as perguntas podem ser complementadas caracterizando uma técnica de pesquisa que permite aos informantes maior liberdade por não condicionar as respostas a um padrão de alternativas.

\subsection{PARTICIPANTES: DELIMITAÇÃO DA AMOSTRA}

Para participação na pesquisa foi selecionada a amostra não probabilística de servidores do INEP integrantes das Diretorias que atuam diretamente com as avaliações do Instituto que tenham impacto na definição, monitoramento e implementação de políticas públicas. Os servidores foram selecionados por fazerem parte das diretorias correlatas à aplicação dos exames. Foram convidados dez servidores e o grupo contou com a participação efetiva de seis deles.

Para participação nas entrevistas, tendo em vista que todos os estados brasileiros aderiram ao Pacto Nacional pela Alfabetização na Idade Certa e tiveram a aplicação da ANA, e indicaram servidores de seu corpo técnico para atuarem no acompanhamento da aplicação das avaliações, foram identificados como informantes-chave os 27 interlocutores responsáveis nos estados pela avaliação nas Secretarias Estaduais de Educação para responderem de que forma os resultados dessas avaliações estão sendo disseminados e utilizados na implementação ou monitoramento de programas e políticas educacionais.

\subsection{PROCEDIMENTOS DE COLETA E ANÁLISE DOS DADOS}

a) Análise Documental

A metodologia de aplicação da Avaliação Nacional da Alfabetização foi analisada à luz 
de sua concepção, logística de aplicação, produção e divulgação de resultados, em 2013 e 2014 com o objetivo de compreender a nova avaliação a compor o escopo do SAEB. Para tanto, foi realizado o exame minucioso de documentos oficiais como: Plano de Aplicação do SAEB com foco na ANA, Relatórios de acompanhamento da aplicação da avaliação, Guia de elaboração de itens e Notas técnicas acerca dos resultados.

Para a construção de uma avaliação de larga escala, o INEP busca formular matrizes de referência para cada avaliação. Uma vez que a aprendizagem não pode ser medida de maneira direta, necessita-se identificar, por meio de um construto e das teorias que o sustentam, as características relacionadas à aprendizagem que sejam diretamente perceptíveis. As matrizes de referência são construídas para aglutinar características que, analisadas conjuntamente, possam gerar informações sobre esse construto. (INEP, 2013)

O objetivo da referida análise foi comparar as matrizes de referência das avaliações externas de alfabetização, ANA e Provinha Brasil, a fim de verificar as possibilidades de comparabilidade ou interpretação integrada de seus resultados, com o objetivo de analisar os resultados pelas redes de ensino estaduais e municipais de educação na busca da construção de um diagnóstico da alfabetização.

As matrizes de referência da Provinha Brasil e da ANA foram analisadas a partir do estudo da concepção de elaboração de cada matriz e seus descritores e dos níveis e escalas de proficiência em que são demonstrados os resultados.

Para ancorar a análise da matriz de referência da Provinha Brasil, foram considerados estudos realizados anteriormente como os de Oliveira e Silva, Morais e Moura (2011, 2012 e 2014) que analisaram criticamente as competências avaliadas a partir das matrizes de referência da Provinha Brasil. A limitação que se impõe no estabelecimento dessa análise comparativa corresponde à ausência, na literatura, de estudos dessa natureza para o exame das matrizes de referência da ANA. A fim de superar tal limitação, foram consultados estudos desenvolvidos por especialistas do INEP acerca das matrizes das avaliações, além de documentos técnicos como o seu "Guia de Elaboração de Itens".

b) Grupo Focal

Para investigação sobre a percepção dos servidores do INEP, técnicos e especialistas em avaliações educacionais, a respeito da ANA, como eixo estruturante do PNAIC e para a construção, juntamente com a Provinha Brasil, de um diagnóstico da alfabetização, foi 
adotada, como técnica de pesquisa qualitativa, o grupo focal. A técnica de grupo focal foi aplicada por uma moderadora, a autora da presente pesquisa, sendo possível, com habilidade, extrair do grupo suas ideias, opiniões e argumentações que sustentem suas declarações.

Para este tipo de pesquisa, foi utilizado um roteiro (Apêndice II) que permitiu investigar o assunto de maneira livre e possibilitou o aprofundamento dos tópicos previamente determinados e dos temas identificados no desenrolar da entrevista.

Ainda de acordo com a literatura conhecida, as características de um grupo focal exigem preparo especial por parte do moderador. Normalmente, é necessário algo mais do que um mero treinamento. Não basta que o moderador domine a técnica, sendo necessário que ele tenha grande domínio do tema sobre o qual a pesquisa trata e conheça os seus objetivos. Por essa razão, é recomendável que o grupo seja conduzido pelo próprio autor do trabalho.

Dessa forma, foi elaborado o roteiro para aplicação da técnica para a qual foram convidados 10 servidores do INEP. Inicialmente, pretendia-se aplicar a técnica de forma piloto, porém, a partir da experiência, foi possível extrair do grupo informações valiosas para a análise e desenvolvimento da pesquisa que convieram como resultados definitivos da técnica aplicada.

O grupo foi realizado no dia 21/08/2014, em uma das salas de reunião do próprio órgão, INEP, no horário de almoço, com duração aproximada de 60 minutos, a fím de não comprometer as demais atividades dos servidores que aceitaram prontamente participar da pesquisa. Compareceram 6 servidores que atuam diretamente com as avaliações educacionais externas, em larga escala, aplicadas pelo órgão. O detalhamento das áreas de atuação dos servidores encontra-se no quadro a seguir.

Quadro 6 - Áreas de atuação dos participantes do grupo focal

\begin{tabular}{lc}
\hline \multicolumn{1}{c}{ Áreas de atuação } & Qtd. \\
\hline Disseminação dos resultados das avaliações & 4 \\
Estruturação das avaliações, instrumentos e escalas & 1 \\
Logística de Aplicação das Avaliações & 1 \\
Total & 6 \\
\hline
\end{tabular}

Fonte: Elaboração Própria 
c) Entrevistas

Para identificar os interlocutores que participariam das entrevistas, foi realizado um estudo acerca das Secretarias de Educação que não dispunham de avaliações próprias de seus sistemas de ensino. O levantamento foi realizado a partir de trabalhos anteriores, como os de Brooke e Cunha (2011) e Horta Neto (2013), além de relatório técnico da ANA que situou os estados que, além de terem sistemas próprios, avaliam especificamente a alfabetização.

Porém, para a presente pesquisa, considerou-se na determinação da amostra de sujeitos entrevistados, a existência ou não de sistemas próprios de avaliação em larga escala, sem com isso, ater-se à avaliação do ciclo de alfabetização. A escolha foi realizada considerando os estados que não dispõem de qualquer sistema próprio de avaliação.

Foram realizadas entrevistas individuais semiestruturadas (ou seja, a partir de um roteiro, Apêndice IV) com técnicos e coordenadores das Secretarias Estaduais de Educação dos Estados de AP, MT, RN, RR, SC, SE e que desempenham, também, a função de interlocutores junto ao INEP no acompanhamento e disseminação das avaliações do Governo Federal no âmbito dos estados. Tais especialistas foram aqui identificados como informanteschave por participarem das avaliações em larga escala para alfabetização aplicadas pelo Governo Federal no acompanhamento e desenvolvimento de ações locais.

Os convites para a participação nas entrevistas ocorreram por telefone, sendo agendadas as entrevistas conforme a disponibilidade dos respondentes e encaminhado a todos via e-mail, termo de consentimento de participação e divulgação das informações. (Apêndice I)

As entrevistas foram realizadas por telefone junto a 6 interlocutores e/ou suplentes estaduais, havendo concordância de todos os entrevistados por sua gravação, totalizando 170 minutos de registro.

O roteiro que norteou as entrevistas foi elaborado previamente e validado no projeto de qualificação desta dissertação, sendo realizadas todas as alterações sugeridas, à época, pela Banca Examinadora. Optou-se por elaborar um roteiro para evitar respostas dicotômicas como "sim" e "não". As questões foram estruturadas de modo que se delimitasse o escopo de entendimento dos entrevistados acerca do objeto de estudo, os quais são as avaliações externas de alfabetização ANA e Provinha Brasil.

Como limites de pesquisa, identificou-se que ao tratar da ANA, por esta fazer parte do escopo de avaliações do SAEB, alguns entrevistados realizaram tal relação, referindo-se ao 
SAEB quando o lócus de pesquisa delimitava-se à avaliação do ciclo de alfabetização. Ressalta-se que houve a opção por não esclarecer os entrevistados acerca dessa diferença e foi permitido o livre discurso sem qualquer interrupção de suas falas.

O roteiro de entrevista foi elaborado a partir de categorias de possibilidade do uso dos resultados das avaliações, anteriormente apontadas nos trabalhos realizados por Brooke e Cunha (2011) sobre a utilização das avaliações estaduais como instrumentos de gestão. No referido estudo, foi produzida uma classificação para os usos dos resultados das avaliações estaduais categorizados em sete níveis, apresentados a seguir:

Figura 9 - Classificação dos usos da avaliação externa

\begin{tabular}{|c|c|c|c|}
\hline \multicolumn{4}{|c|}{$\begin{array}{l}\text { Quadro 1. Classificação dos usos da avaliação externa } \\
\text { como instrumento da gestão educacional nos estados }\end{array}$} \\
\hline & $\begin{array}{l}\text { Uso dos resultados } \\
\text { da avaliação } \\
\text { (Política de gestäo) }\end{array}$ & $\begin{array}{l}\text { Sem consequências ou } \\
\text { consequências menores } \\
\text { (low-stakes) }\end{array}$ & $\begin{array}{l}\text { Com consequências } \\
\text { importantes (high-stakes) }\end{array}$ \\
\hline 1 & $\begin{array}{l}\text { Para avaliar e orientar a } \\
\text { política educacional }\end{array}$ & 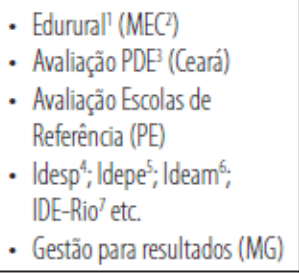 & $\begin{array}{l}\text { - } \text { PAR }^{9}(M E C) \\
\text { - Prog. Escolas-Padrão (SP) }\end{array}$ \\
\hline 2 & $\begin{array}{l}\text { Para informar as escolas } \\
\text { sobre a aprendizagem } \\
\text { dos alunos e definir as } \\
\text { estratégias de formação } \\
\text { continuada }\end{array}$ & $\begin{array}{l}\text { - Boletim de Resultados (PE) } \\
\text { - Relatório Pedagógico (DF) } \\
\text { - } \mathrm{PIP}^{8} \text { (MG) }\end{array}$ & \\
\hline 3 & Para informar ao público & $\begin{array}{l}\text { - Boletim da escola (Paraná) } \\
\text { - Propaganda política (MG) }\end{array}$ & - Escolha de escola (Chile) \\
\hline 4 & Para a alocação de recursos & $\begin{array}{l}\text { - Aprender Mais (PE) } \\
\text { - Escola Referência (MG) }\end{array}$ & $\begin{array}{l}\text { - Escola Nota } 10 \text { (CE) } \\
\text { - Indice Municipal de } \\
\text { Qualidade Educacional (CE) } \\
\end{array}$ \\
\hline 5 & $\begin{array}{l}\text { Para políticas de incentivos } \\
\text { salariais }\end{array}$ & & $\begin{array}{l}\text { - Acordo de Resultados (MG) } \\
\text { - Escola Nota } 10 \text { (CE) } \\
\text { - Bonificação por } \\
\text { Desempenho (SP) }\end{array}$ \\
\hline 6 & $\begin{array}{l}\text { Como componente da } \\
\text { política de avaliaçäo docente }\end{array}$ & & $\begin{array}{l}\text { - } A D 1^{10}(M G) \\
\text { - Recondução de diretores (DF) }\end{array}$ \\
\hline 7 & $\begin{array}{l}\text { Para a certificação de alunos } \\
\text { e escolas }\end{array}$ & & 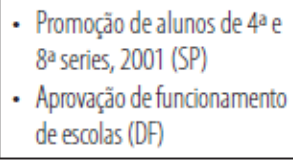 \\
\hline & 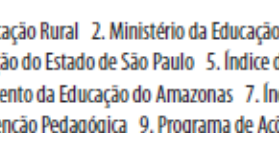 & 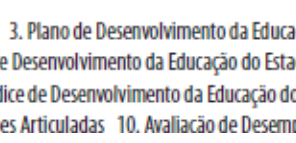 & $\begin{array}{l}\text { ào 4. Indice de Desenvolvimento da } \\
\text { lo de Pernambuco 6. Indicede Desen- } \\
\text { Estado do Rio de Janeiro 8. Planode } \\
\text { enho Individual }\end{array}$ \\
\hline
\end{tabular}

Fonte: Brooke e Cunha (2011)

Considerando o levantamento dessa classificação, foi realizada uma adaptação das categorias para a construção de um instrumento de pesquisa com questões abertas que 
possibilitasse coletar a percepção dos interlocutores acerca da apropriação e os usos dos resultados das avaliações Provinha Brasil e ANA em seus estados. Ressalta-se que por tratarse de avaliações da alfabetização, não foi considerada como categoria relevante de pesquisa o uso das avaliações para certificação de alunos, tendo em vista que nesse ciclo não há que se falar em certificação. Além disso, o escopo da ANA e da Provinha Brasil não incluem etapas de conclusão de níveis de escolarização e são aplicadas apenas para turmas de ensino regulares, o que anula a possibilidade de certificação por turmas de jovens e adultos. 


\section{ANÁLISE E DISCUSSÃO DOS RESULTADOS DA PESQUISA}

\subsection{COMPREENDENDO A METODOLOGIA DE APLICAÇÃO E DIVULGAÇÃO DE RESULTADOS DA ANA}

a) Aplicação da ANA em 2013

A primeira edição da ANA foi aplicada no período de 11 a 27 de novembro de 2013. Os testes destinados a aferir os níveis de alfabetização e desempenho em alfabetização e letramento em língua portuguesa e alfabetização em matemática foram compostos por 20 itens. No caso de língua portuguesa, 17 itens objetivos de múltipla escolha e 3 itens de produção escrita. No caso de matemática, 20 itens objetivos de múltipla escolha.

Os itens de produção escrita da ANA demandaram dos alunos a redação de duas palavras e uma produção textual. As habilidades avaliadas nos itens de produção escrita da ANA foram:

- Grafar palavras com estrutura silábica canônica;

- Grafar palavras com estrutura silábica não canônica; e

- Produzir um texto a partir de situação dada.

No ano de 2013, foram utilizados 157 itens nas duas áreas avaliadas, dos quais 80 foram de matemática do tipo múltipla escolha, 68 de leitura do tipo múltipla escolha e nove itens de resposta construída em escrita. Cada teste de língua portuguesa continha 17 itens de leitura e 3 itens de produção escrita, totalizando 20 itens, enquanto cada teste de matemática continha 20 itens objetivos.

A avaliação foi aplicada em um único dia para cada turma e metade dos alunos realizou os testes de língua portuguesa, incluindo a produção escrita, enquanto a outra metade realizou os testes de matemática de maneira que os resultados da turma refletissem o desempenho médio nas duas áreas. Todos os estudantes, porém, responderam os itens de produção escrita.

Ressalta-se que por questões metodológicas e, devido à pouca idade dos alunos submetidos à avaliação externa, as questões objetivas eram preenchidas pelos alunos nos cadernos de provas e posteriormente transcritas pelos aplicadores responsáveis pela aplicação dos testes em sala de aula.

Na edição de 2013 da ANA, foram oferecidos testes adaptados para língua portuguesa como segunda língua, e traduzidos para Libras no caso do teste de matemática. Averiguou-se, 
porém, que a adaptação precisaria ser estudada, haja vista que o processo de alfabetização dos estudantes surdos em língua portuguesa ocorre como segunda língua e como segunda modalidade.

Com base nos dados do Censo Escolar 2012, a previsão de aplicação da ANA foi para um total de 2.899 .178 matriculados no $3^{\circ}$ ano do ensino fundamental de 100.538 escolas públicas, conforme é apresentado no Quadro 7.

Quadro 7 - Quantitativos previstos para aplicação da ANA 2013

\begin{tabular}{lcccc}
\hline & Municípios & Escolas & Turmas & Alunos \\
\hline Rede Federal regular & 15 & 23 & 64 & 1.475 \\
Rede Estadual regular & 2.429 & 10.589 & 21.953 & 522.225 \\
Rede Municipal regular & 5.472 & 44.810 & 92.355 & 2.121 .181 \\
Rede Estadual multisseriada & 769 & 2.259 & 2.615 & 12.846 \\
Rede Municipal multisseriada & 3.494 & 42.857 & 48.287 & 241.451 \\
TOTAL & $\mathbf{5 . 5 6 5}$ & $\mathbf{1 0 0 . 5 3 8}$ & $\mathbf{1 6 5 . 2 7 4}$ & $\mathbf{2 . 8 9 9 . 1 7 8}$ \\
\hline
\end{tabular}

Fonte: INEP/ Censo Escolar 2012

Os resultados de desempenho nas áreas avaliadas são expressos em escalas de proficiência, que serão melhor detalhadas na próxima seção do trabalho. As escalas de língua portuguesa (Leitura) e de matemática da ANA 2013 são compostas por quatro níveis progressivos e cumulativos (conforme se verifica no Apêndice V).

Além de aferir os níveis de proficiência em leitura, escrita e matemática, a ANA apresenta indicadores contextuais que informam sobre as condições em que ocorre o trabalho escolar. Tais indicadores devem ser considerados na análise dos resultados. Nesta primeira edição, foram disponibilizados dois indicadores contextuais: o Indicador de Nível Socioeconômico e o Indicador de Formação Docente. Além disso, o INEP também disponibilizou o Perfil de "Escolas Similares", de acordo com o que é mostrado na Figura 10: 
Figura 10 - Indicadores contextuais ANA 2013

\section{INDICADORES CONTEXTUAIS}

O Indicador de Nivel Socioeconômico e o Indicador de Adequaçăo da Formaçăo Docente produzem informações sobre o contexto em que cada escola desenvolve o trabalho educativo.

O Indicador de Nivel Socioeconômico possibilita, de modo geral, situar o público atendido pela escola em um estrato ou nível social, apontando o padrăo de vida referente a cada um de seus estratos. Esse indicador é calculado a partir da escolaridade dos pais e da posse de bens e contratação de serviços pela familia dos alunos. Para melhor caracterizar as escolas foram criados sete grupos, de modo que, no Grupo 1, estão as escolas com nivel socioecono̊mico mais baixo e, no Grupo 7, com nivel socioeconômico mais alto.

O Indicador de Formaçăo Docente analisa, em cada escola, a formação dos docentes dos anos iniciais do Ensino Fundamental que lecionam Língua Portuguesa e Matemática. Apresenta, assim, o percentual de disciplinas de Língua Portuguesa e Matemática que são regidas por professores com Licenciatura em Pedagogia/Normal Superior, Licenciatura em Letras-Língua Portuguesa ou Matemática, respectivamente.

NIVEL SOCIOECONÔMICO

Grupo 5
FORMAÇĀO DOCENTE

\section{$64,66 \%$}

Fonte: INEP/Boletim Escolar, ANA, 2013

Apesar de ter sido aplicada em novembro de 2013, os resultados da ANA somente foram disponibilizados em setembro de 2014. Por questões metodológicas no cálculo das proficiências, o processo de divulgação dos resultados da ANA foi postergado por duas vezes. Esse processo de publicidade é composto por três etapas principais: divulgação dos resultados preliminares, interposição de recursos e divulgação dos resultados finais.

A divulgação preliminar é restrita aos diretores escolares ou responsáveis legais pela instituição. Nessa etapa, o INEP disponibiliza um sistema eletrônico em que cada diretor pode visualizar a quantidade de estudantes previstos e presentes durante a aplicação da avaliação e a distribuição dos alunos por nível de proficiência em Leitura e matemática. Para ter seus resultados divulgados, a escola tem que cumprir alguns critérios específicos de participação.

O INEP disponibilizou aos diretores de escolas um sistema para verificação preliminar dos resultados da ANA e interposição de recursos. Foi realizada uma análise das solicitações recebidas pela Diretoria responsável e os 432 recursos que foram agrupados em três categorias conforme o Quadro 8, a seguir:

Quadro 8 - Quantitativo de recursos interpostos contra os resultados da ANA

\begin{tabular}{lc}
\hline \multicolumn{1}{c}{ Motivo do Recurso } & Quantidade \\
\hline Quantidade de estudantes que participaram & 201 \\
Problemas ocorridos na aplicação & 118 \\
Aplicação ocorreu, mas não foram divulgados resultados preliminares. & 113 \\
Total de Recursos & $\mathbf{4 3 2}$ \\
\hline
\end{tabular}

Fonte: Elaboração própria (2015)

Quanto ao primeiro motivo de recurso das escolas e redes estaduais e municipais de ensino, foram recebidos 201 recursos que questionavam a quantidade de alunos que 
participaram da avaliação. 118 diretores contestaram os resultados da avaliação sob a alegação de que problemas ocorridos durante a aplicação possam ter comprometido seus resultados e 113 gestores alegaram que seus alunos realizaram as provas, mas não tiveram seus resultados divulgados.

A partir dos problemas apontados foi possível verificar e corrigir possíveis incorreções no percentual de divulgação ou problemas, no processamento das informações para cálculo de proficiências e divulgação de resultados. As mesmas categorias foram utilizadas para a interposição de recursos no ano de 2014. Em 2013, os critérios de divulgação foram a participação mínima de $50 \%$ de estudantes nos testes de Leitura, Escrita e Matemática, considerando o número de matrículas declaradas ao Censo Escolar, e a presença de pelo menos 10 estudantes no momento da avaliação.

Os resultados foram apresentados de acordo com a previsão de alunos que deveriam participar da ANA com base no Censo Escolar 2012 e a quantidade de alunos que realmente participaram. Isso decorre do fato de que em 2013 a ANA era aplicada em um único dia onde metade da turma realizava a avaliação de língua portuguesa, a outra de matemática e todos realizavam a prova de escrita (vide Figura 11).

Figura 11 - Participação na avaliação ANA 2013

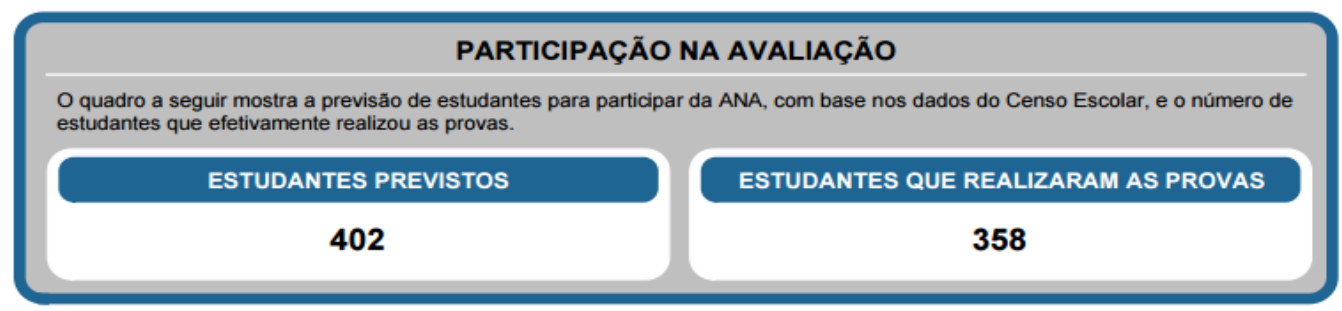

Fonte: INEP/Boletim Escolar, ANA, 2013.

b) Aplicação da ANA em 2014

No ano de 2014 , o total de matrículas no $1^{\circ}$, no $2^{\circ}$ e no $3^{\circ}$ ano do ensino fundamental no Brasil foi, respectivamente, de 2.724.433, 2.794.143 e 3.053.470 alunos. Por região, a maior concentração de matrículas nos três anos está no Sudeste - 1.136 .533 alunos, e a menor concentração, no Centro-Oeste - 215.666 alunos. Por unidade da Federação, o maior número de matrículas é o de São Paulo - 590.049 alunos, e o menor, o de Roraima - 6.876 alunos. Esses dados tendem a acompanhar a proporção demográfica territorial e, no que tange à localização, a maioria das matrículas encontra-se nas escolas localizadas em zona urbana. As 
matrículas nas escolas privadas representam, aproximadamente, $20 \%$ do total do Ciclo. (INEP, 2014)

No ano de 2014, foram utilizados 169 itens no total, entre os quais 80 foram de matemática do tipo múltipla escolha, 80 de leitura do tipo múltipla escolha e nove de resposta construída em escrita. Diferentemente do ano anterior, na edição de 2014 cada teste de língua portuguesa continha 20 itens de leitura e três itens de produção escrita, enquanto cada teste de matemática continuou a apresentar 20 itens.

A técnica adotada para a composição dos cadernos deu origem a 32 cadernos de prova, sendo 16 cadernos de língua portuguesa (Leitura) e 16 de matemática nas duas edições 20132014. Na edição de 2014, mudou-se a metodologia de aplicação de maneira que cada turma respondesse aos dois testes, desdobrando-se a aplicação em dois dias. No primeiro dia, foi aplicado o teste de língua portuguesa (20 itens de Leitura e 3 de Escrita), e no segundo dia, foi aplicado o teste de Matemática (20 itens). A aplicação do teste de questões objetivas teve duração de 1 hora, e o de produção escrita foi aplicado em 30 minutos.

A partir da publicação da Lei $\mathrm{n}^{\circ} 13.005$, de 25 de junho de 2014, o critério de participação mínima para divulgação foi elevado para $80 \%$ dos estudantes matriculados. Também foi exigida a presença de, no mínimo, 10 estudantes presentes no momento da avaliação.

Dessa, forma, após a divulgação preliminar dos resultados no ano de 2014, os gestores escolares também tiveram a oportunidade de interpor recursos quanto aos resultados divulgados (vide Quadro 9).

Quadro 9 - Quantitativo de recursos interpostos contra os resultados da ANA 2014

\begin{tabular}{lc}
\hline \multicolumn{1}{c}{ Motivo do Recurso } & Quantidade \\
\hline Quantidade de estudantes que participaram & 393 \\
$\begin{array}{l}\text { Aplicação ocorreu, mas não foram divulgados resultados } \\
\text { preliminares. }\end{array}$ & 125 \\
Total de Recursos & $\mathbf{5 1 8}$ \\
\hline
\end{tabular}

Fonte: Elaboração própria (2015)

A divulgação de resultados em 2014 foi realizada através da divulgação do Boletim da Escola, que reuniu todas as informações apresentando, além do boletim de desempenho dos alunos nos níveis descritos nas escalas de proficiência, os indicadores contextuais, que 
apresentam informações sobre o contexto em que cada escola desenvolve o trabalho educativo.

O primeiro indicador é Nível Socioeconômico, que possibilita situar o público atendido por sua escola em um estrato ou nível social, apontando o padrão de vida dos estudantes. $\mathrm{O}$ indicador considera a escolaridade dos pais, a posse de bens e a contratação de serviços pela família dos alunos. Diferente de 2013, para caracterizar as escolas, foram criadas sete categorias de nível socioeconômico: muito baixo, baixo, médio baixo, médio, médio alto, alto e muito alto. O segundo indicador é o de adequação da Formação Docente, que oferece o percentual de disciplinas que são ministradas por professores com formação adequada, conforme mostrado na Figura 12.

Figura 12 - Indicadores contextuais ANA 2014

\section{INDICADORES CONTEXTUAIS}

Os indicadores contextuais apresentam informações sobre o contexto em que cada escola desenvolve o trabalho educativo.

O Indicador de Nível Socioeconômico possibilita, de modo geral, situar o público atendido pela escola em um estrato ou nível social, apontando o padrão de vida referente a cada um de seus estratos. Esse indicador foi calculado a partir da escolaridade dos pais e da posse de bens e contratação de serviços pela família dos estudantes que realizaram a Prova Brasil 2013. Para melhor caracterizar as escolas, foram criadas sete categorias de nível socioeconômico: muito baixo, baixo, médio baixo, médio, médio alto, alto e muito alto.

0 Indicador de Adequação da Formação Docente, por sua vez, oferece o percentual de disciplinas que são ministradas por professores com formação adequada. Apresenta, assim, o percentual de disciplinas de Língua Portuguesa e Matemática que são regidas por professores com Licenciatura em Pedagogia/Normal Superior, Licenciatura em Letras-Língua Portuguesa ou Licenciatura em Matemática.

Para conhecer mais indicadores educacionais de sua escola, acesse o Portal do Inep (idebescola.inep.gov.br/ideb/consulta-publica). Neste endereço, você poderá consultar informações como infraestrutura, complexidade da gestão escolar, prática pedagógica inclusiva, organização, taxas de matrículas, aprovação, reprovação, abandono, distorção idade-série, entre outras informações relevantes da sua instituição escolar.

NÍVEL SOCIOECONÔMICO

Médio

\section{FORMAÇÃO DOCENTE}

$75 \%$

Fonte: INEP/Boletim Escolar, ANA, 2014.

A terceira parte do Boletim refere-se à participação dos estudantes da escola na ANA. Como a aplicação da avaliação ocorreu em dois dias, a primeira linha apresenta a quantidade de alunos previstos. Esse número é informado de acordo com os dados do Censo Escolar. A segunda linha apresenta a quantidade de alunos presentes no momento da avaliação. Esse número pode variar de acordo com a disciplina, pois os testes foram realizados em dois dias. No primeiro dia, foi realizado o teste de língua portuguesa (Leitura e Escrita), e no segundo dia, os testes de matemática. A última linha apresenta o quantitativo de presentes válidos. Essa informação é importante para que a escola conheça a quantidade de alunos que conseguiram responder a três ou mais questões dos testes objetivos. Ou seja, a diferença entre os presentes e os presentes válidos indica aqueles alunos que compareceram no dia do teste, 
mas não conseguiram responder a avaliação (vide Figura 13). Essa mesma diferença, em Escrita, indica alunos presentes que não responderam às questões discursivas. (INEP, 2015)

Figura 13 - Participação dos estudantes por escola ANA 2014

\begin{tabular}{|c|c|c|c|}
\hline \multicolumn{4}{|c|}{ PARTICIPAÇÃO DOS ESTUDANTES DE SUA ESCOLA } \\
\hline Estudantes & Leitura & Escrita & Matemática \\
\hline $\begin{array}{l}\text { PREVISTOS } \\
\text { Total de estudantes matriculados em sua escola, no } 3^{\circ} \text { ano } \\
\text { do Ensino Fundamental, de acordo com o Censo Escolar } 2014 .\end{array}$ & 35 & 35 & 35 \\
\hline $\begin{array}{l}\text { PRESENTES } \\
\text { Total de estudantes matriculados em sua escola, no } 3^{\circ} \text { ano do } \\
\text { Ensino Fundamental, que estavam presentes no dia da aplicaçăo } \\
\text { dos testes da ANA, de acordo com o Censo Escolar } 2014 \text {. }\end{array}$ & 30 & 30 & 32 \\
\hline $\begin{array}{l}\text { PRESENTES VÁLIDOS } \\
\text { Total de estudantes matriculados em sua escola, no } 3^{\circ} \text { ano do Ensino } \\
\text { Fundamental, que estavam presentes e que responderam a tês ou } \\
\text { mais questöes dos testes objetivos (Leitura ou Matemática), de acordo } \\
\text { com o Censo Escolar } 2014 \text {. }\end{array}$ & 28 & 28 & 29 \\
\hline
\end{tabular}

Fonte: INEP/Boletim Escolar, ANA, 2014

Figura 14 - Distribuição de estudantes por nível de proficiência em leitura

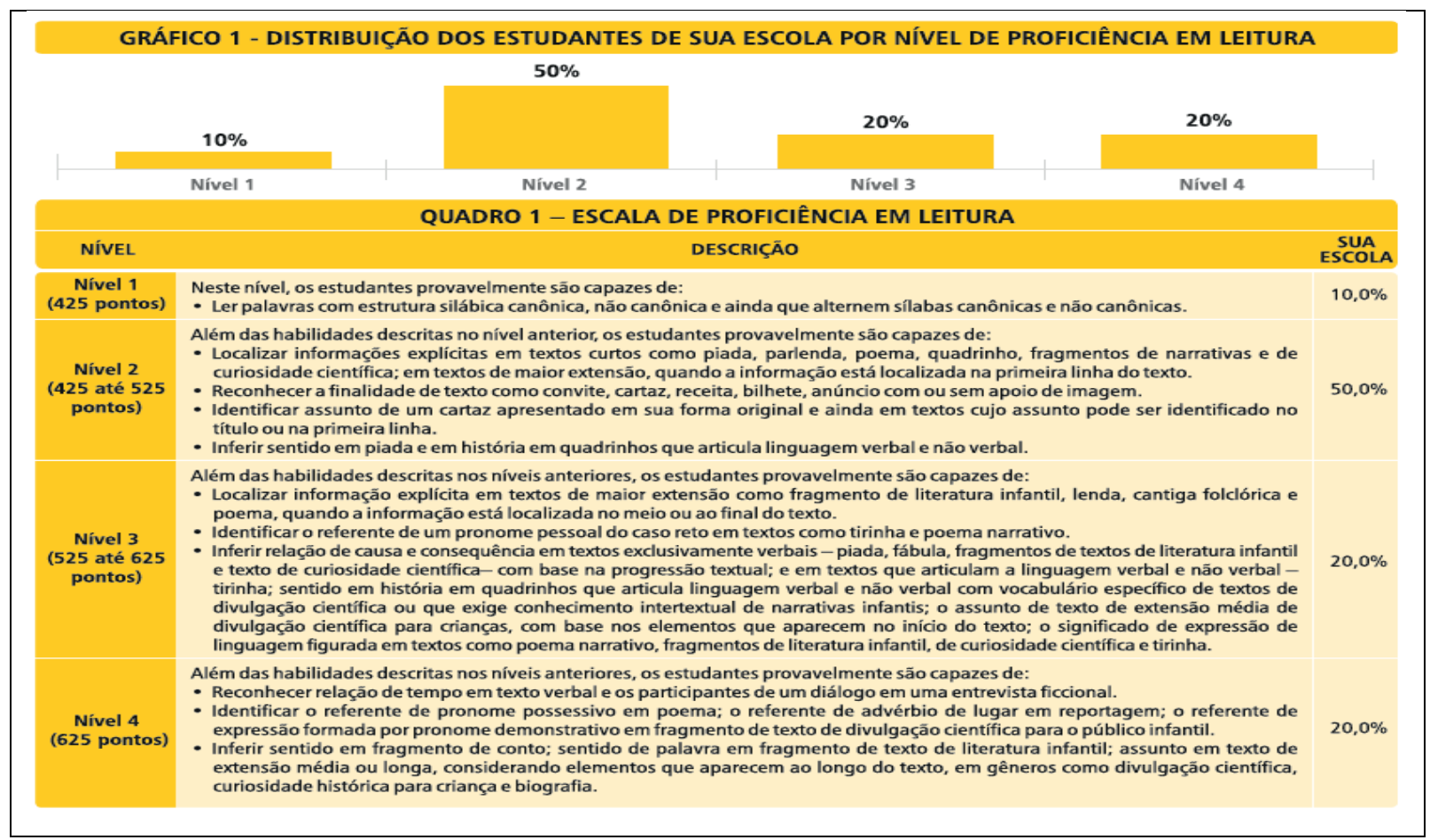

Fonte: INEP/Boletim Escolar, ANA, 2014.

Em 2014, o INEP inovou na forma de divulgação dos resultados da ANA, com a organização dos dados através do Painel Educacional, que apresenta os dados consolidados, agregados por estado e município, e divididos em três abas de i) Trajetória: que apresenta dados do Censo da Educação Básica coletados pelo INEP ii) Contexto: que apresenta os 
indicadores produzidos a partir dos questionários contextuais; iii) Aprendizagem: que apresenta resultados de Avaliações aplicadas, conforme demonstra a Figura 15.

Figura 15 - Painel Educacional ANA

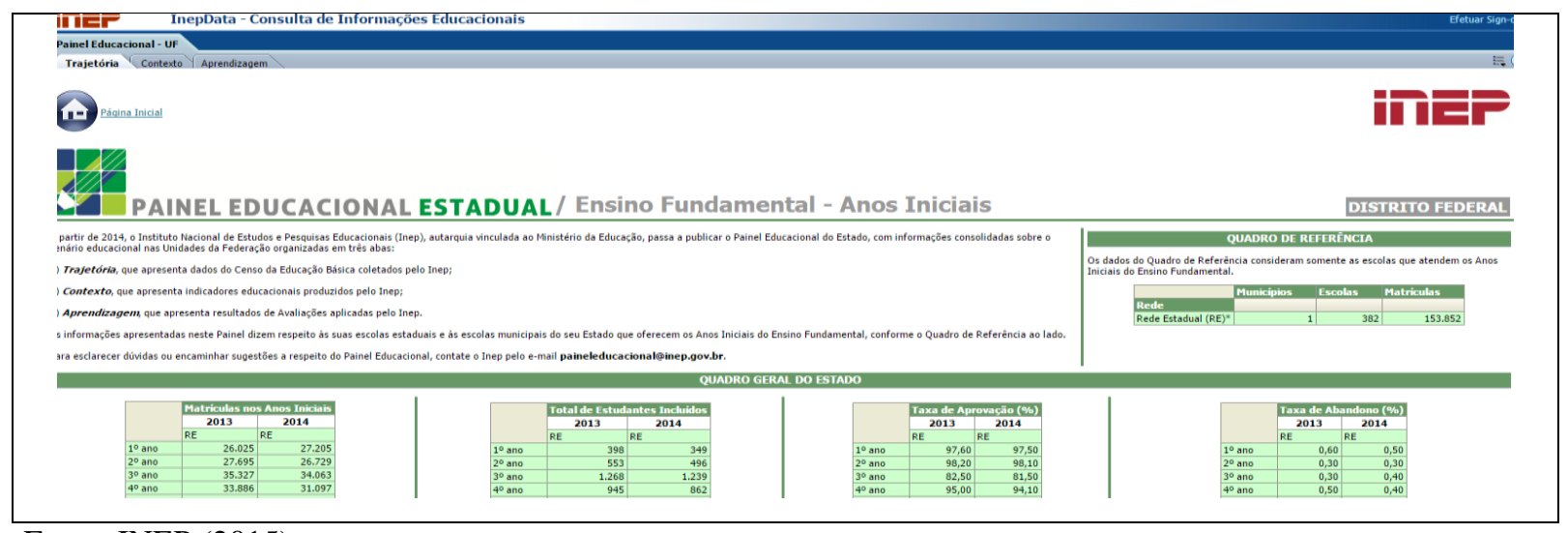

Fonte: INEP (2015)

c) O que revelam os primeiros resultados

Os resultados da ANA em 2013 e 2014 somente foram divulgados no segundo semestre do ano posterior ao de sua aplicação, portanto, a análise apresentada retrata apenas um panorama geral dos primeiros resultados produzidos pelas avaliações, sem a pretensão de aprofundar o estudo, em decorrência da limitação temporal.

Foram analisados os resultados relativos ao teste de Leitura, por Unidade da Federação, nos dois anos de aplicação da avaliação. No quadro 10 abaixo, são apresentados os resultados de 2013:

Quadro 10 - Percentual de alunos, por UF, por nível de proficiência na ANA 2013 - Leitura

\begin{tabular}{l|cccc}
\multicolumn{1}{c|}{ Estado } & Nível 1 & Nível 2 & Nível 3 & Nível 4 \\
\hline Acre & $13,73 \%$ & $33,61 \%$ & $41,05 \%$ & $11,61 \%$ \\
Alagoas & $50,49 \%$ & $31,75 \%$ & $14,61 \%$ & $3,14 \%$ \\
Amapá & $43,92 \%$ & $33,53 \%$ & $19,86 \%$ & $2,69 \%$ \\
Amazonas & $19,71 \%$ & $35,95 \%$ & $35,26 \%$ & $9,08 \%$ \\
Bahia & $38,78 \%$ & $34,06 \%$ & $23,16 \%$ & $4,01 \%$ \\
Ceará & $17,72 \%$ & $31,94 \%$ & $32,58 \%$ & $17,76 \%$ \\
Distrito Federal & $15,09 \%$ & $34,64 \%$ & $39,92 \%$ & $10,35 \%$ \\
Espírito Santo & $15,71 \%$ & $29,85 \%$ & $39,59 \%$ & $14,85 \%$ \\
Goiás & $13,81 \%$ & $30,84 \%$ & $42,43 \%$ & $12,92 \%$ \\
Maranhão & $32,67 \%$ & $37,39 \%$ & $24,94 \%$ & $5,00 \%$ \\
Mato Grosso & $21,20 \%$ & $35,69 \%$ & $35,06 \%$ & $8,05 \%$ \\
Mato Grosso do Sul & $13,30 \%$ & $35,00 \%$ & $40,50 \%$ & $11,20 \%$
\end{tabular}




\begin{tabular}{l|cccc} 
Minas Gerais & $9,64 \%$ & $23,18 \%$ & $43,54 \%$ & $23,64 \%$ \\
Paraná & $8,43 \%$ & $34,62 \%$ & $38,30 \%$ & $18,65 \%$ \\
Paraíba & $36,19 \%$ & $38,16 \%$ & $22,30 \%$ & $3,35 \%$ \\
Pará & $42,76 \%$ & $36,30 \%$ & $17,98 \%$ & $2,97 \%$ \\
Pernambuco & $31,58 \%$ & $33,08 \%$ & $26,36 \%$ & $8,99 \%$ \\
Piaú & $26,04 \%$ & $38,49 \%$ & $30,13 \%$ & $5,34 \%$ \\
Rio de Janeiro & $15,55 \%$ & $33,89 \%$ & $38,23 \%$ & $12,33 \%$ \\
Rio Grande do Norte & $36,02 \%$ & $34,77 \%$ & $23,85 \%$ & $5,36 \%$ \\
Rio Grande do Sul & $17,59 \%$ & $31,53 \%$ & $38,95 \%$ & $11,94 \%$ \\
Rondônia & $12,74 \%$ & $34,37 \%$ & $40,52 \%$ & $12,37 \%$ \\
Roraima & $23,66 \%$ & $37,24 \%$ & $31,32 \%$ & $7,78 \%$ \\
Santa Catarina & $12,89 \%$ & $30,68 \%$ & $42,51 \%$ & $13,92 \%$ \\
Sergipe & $40,81 \%$ & $36,85 \%$ & $19,38 \%$ & $2,96 \%$ \\
São Paulo & $13,07 \%$ & $29,06 \%$ & $42,52 \%$ & $15,35 \%$ \\
Tocantins & $25,94 \%$ & $38,98 \%$ & $28,73 \%$ & $6,35 \%$
\end{tabular}

Fonte: INEP - adaptado pela autora

Em 2013, primeiro ano de aplicação da ANA, observa-se que a maior parte dos alunos brasileiros encontra-se nos níveis 2 e 3 da escala de proficiência em Leitura. Os resultados demonstraram que os Estados das regiões Norte e Nordeste possuem o maior percentual de alunos concentrados nos níveis 1 e 2 da escala, os mais elementares.

O Estado que apresenta o menor percentual de alunos com nível 4 de proficiência é o Amapá, com 2,69\% dos seus alunos do $3^{\circ}$ ano do ensino fundamental que detém as habilidades necessárias para a alfabetização ao final do ciclo de três anos. O Estado com a maior concentração de alunos no nível 4 de proficiência foi Minas Gerais com 23,64\% dos alunos.

Destaca-se o estado de Alagoas com mais da metade do percentual de seus alunos no nível 1 de proficiência, correspondente à 50,49\% dos alunos, enquanto o estado com menor percentual de alunos concentrados no nível 1 da escala é o estado do Paraná, com 8,43\% dos alunos.

Os alunos nos níveis 2 e 3 da escala de leitura, onde está concentrada a maior parte dos alunos brasileiros, possuem as habilidades descritas no Quadro 11 abaixo: 
Quadro 11 - Exemplos de níveis da escala de proficiência de Leitura da ANA

Nível 2: Maior que 425 até 525 pontos
Identificar a finalidade de textos como convite, cartaz, texto instrucional (receita) e bilhete.

Localizar informação explícita em textos curtos (com até cinco linhas) em gêneros como piada, parlenda, poema, tirinha (história em quadrinhos em até três quadros), texto informativo e texto narrativo.

Identificar o assunto de textos, cujo assunto pode ser identificado no título ou na primeira linha em gêneros como poema e texto informativo.

Inferir o assunto de um cartaz apresentado em sua forma estável, com letras grandes e mensagem curta e articulação da linguagem verbal e não verbal.
Nível 3: Maior que 525 até 625 pontos
Inferir o assunto de texto de divulgação científica para crianças.

Localizar informação explícita, situada no meio ou final do texto, em gêneros como lenda e cantiga folclórica.

Identificar o referente de um pronome pessoal do caso reto em gêneros como tirinha e poema narrativo.

Inferir relação de causa e consequência em gêneros como tirinha, anedota, fábula e texto de literatura infantil.

Inferir sentido com base em elementos verbais e não verbais em tirinha.

Reconhecer significado de expressão de linguagem figurada em gêneros como poema narrativo, texto de literatura infantil e tirinha.

Fonte: INEP - adaptado pela autora

A mesma análise foi realizada nos dados de Leitura de 2014. O quadro a seguir traz os resultados da ANA em 2014 com o percentual de alunos concentrados em cada um dos níveis de proficiência:

Quadro 12 - Percentual de alunos, por UF, por nível de proficiência na ANA 2014 - Leitura

\begin{tabular}{l|cccc}
\multicolumn{1}{c}{ Estado } & Nível 1 & Nível 2 & Nível 3 & Nível 4 \\
\cline { 2 - 5 } Acre & $15,04 \%$ & $36,09 \%$ & $37,24 \%$ & $11,62 \%$ \\
Alagoas & $46,79 \%$ & $34,88 \%$ & $16,12 \%$ & $2,21 \%$ \\
Amapá & $42,77 \%$ & $35,33 \%$ & $18,65 \%$ & $3,24 \%$ \\
Amazonas & $20,35 \%$ & $37,31 \%$ & $32,97 \%$ & $9,37 \%$ \\
Bahia & $24,70 \%$ & $27,40 \%$ & $34,07 \%$ & $13,84 \%$ \\
Ceará & $22,91 \%$ & $27,61 \%$ & $29,28 \%$ & $20,19 \%$ \\
Distrito Federal & $12,66 \%$ & $34,22 \%$ & $40,72 \%$ & $12,40 \%$ \\
Espírito Santo & $14,85 \%$ & $31,18 \%$ & $38,74 \%$ & $15,22 \%$ \\
Goiás & $10,90 \%$ & $30,59 \%$ & $43,23 \%$ & $15,28 \%$
\end{tabular}




\begin{tabular}{l|cccc} 
Maranhão & $36,46 \%$ & $34,81 \%$ & $24,30 \%$ & $4,43 \%$ \\
Mato Grosso & $17,51 \%$ & $35,76 \%$ & $35,80 \%$ & $10,94 \%$ \\
Mato Grosso do Sul & $12,11 \%$ & $38,23 \%$ & $39,32 \%$ & $10,34 \%$ \\
Minas Gerais & $7,36 \%$ & $23,81 \%$ & $43,21 \%$ & $25,63 \%$ \\
Paraná & $11,47 \%$ & $29,88 \%$ & $44,65 \%$ & $14,00 \%$ \\
Paraíba & $37,10 \%$ & $37,24 \%$ & $21,69 \%$ & $3,96 \%$ \\
Pará & $41,73 \%$ & $36,75 \%$ & $18,39 \%$ & $3,13 \%$ \\
Pernambuco & $32,48 \%$ & $32,29 \%$ & $24,24 \%$ & $10,98 \%$ \\
Piauí & $22,05 \%$ & $38,40 \%$ & $31,86 \%$ & $7,69 \%$ \\
Rio de Janeiro & $4,21 \%$ & $32,75 \%$ & $44,22 \%$ & $18,82 \%$ \\
Rio Grande do Norte & $32,63 \%$ & $34,38 \%$ & $26,14 \%$ & $6,85 \%$ \\
Rio Grande do Sul & $15,10 \%$ & $32,23 \%$ & $39,08 \%$ & $13,59 \%$ \\
Rondônia & $15,65 \%$ & $35,76 \%$ & $36,14 \%$ & $12,44 \%$ \\
Roraima & $11,75 \%$ & $29,31 \%$ & $43,13 \%$ & $15,81 \%$ \\
Santa Catarina & $12,02 \%$ & $30,67 \%$ & $41,54 \%$ & $15,77 \%$ \\
Sergipe & $40,29 \%$ & $36,00 \%$ & $20,43 \%$ & $3,28 \%$ \\
São Paulo & $10,77 \%$ & $28,12 \%$ & $42,60 \%$ & $18,51 \%$ \\
Tocantins & $20,89 \%$ & $35,27 \%$ & $34,15 \%$ & $9,69 \%$
\end{tabular}

Fonte: INEP - adaptado pela autora

É possível observar que não houve alteração significativa dos resultados da ANA 2014 em relação à 2013. A maior parte dos alunos continua concentrada nos níveis 2 e 3 da escala de proficiência, considerando todas as Unidades da Federação. Os estados das regiões Norte e Nordeste continuam concentrando o maior percentual dos alunos nos níveis 1 e 2 da escala.

Destacam-se como esforços positivos, o Estado de Roraima, cujo percentual de alunos concentrados no nível 1 da escala de proficiência diminuiu de 23,66\% para 11,75\%, com o aumento proporcional do percentual de alunos concentrados nos níveis 3 e 4 . E o Estado da Bahia, que apesar de seguir a média nacional com a maior parte dos alunos concentrados nos níveis 2 e 3 da escala, diminuiu de 38,78\% para $24,70 \%$ os alunos no nível 1 e aumentou de $4,01 \%$ para $13,84 \%$ o percentual de alunos no nível 4 da escala de proficiência.

Importante ressaltar que de 2013 para 2014 a ANA teve sua metodologia de aplicação modificada, passando de um dia de aplicação, com metade da turma realizando as provas de Língua Portuguesa e a outra metade realizando as provas de Matemática, para dois dias de aplicação com todos os alunos da turma realizando ambos os testes. Porém, tal alteração na metodologia não é impeditivo para a comparabilidade entre os resultados produzidos em 2013 e 2014 .

Os dados demonstram o que já vem sendo apontado pelos resultados do último IDEB, divulgado em 2013. Os Estados que concentram os melhores índices, são os mesmos que 
apresentaram a melhor distribuição de alunos em níveis mais elevados da escala de proficiência da ANA nos anos de 2013 e 2014.

O Estado do Amapá, com o menor percentual de alunos no nível 4 da escala de proficiência em Leitura na aplicação da ANA em 2013 (apenas 2,69\%) foi também o estado com o menor Ideb do Brasil em 2013, correspondente à 4,0 para os anos iniciais do Ensino Fundamental. Abaixo, são apresentados os dados divulgados pela plataforma Qedu, que demonstram o percentual de alunos do $5^{\circ}$ ano do Ensino Fundamental com aprendizado considerado “adequado” em Língua Portuguesa na Prova Brasil 2013:

Figura 16 - Percentual de alunos com aprendizado adequado em Língua Portuguesa

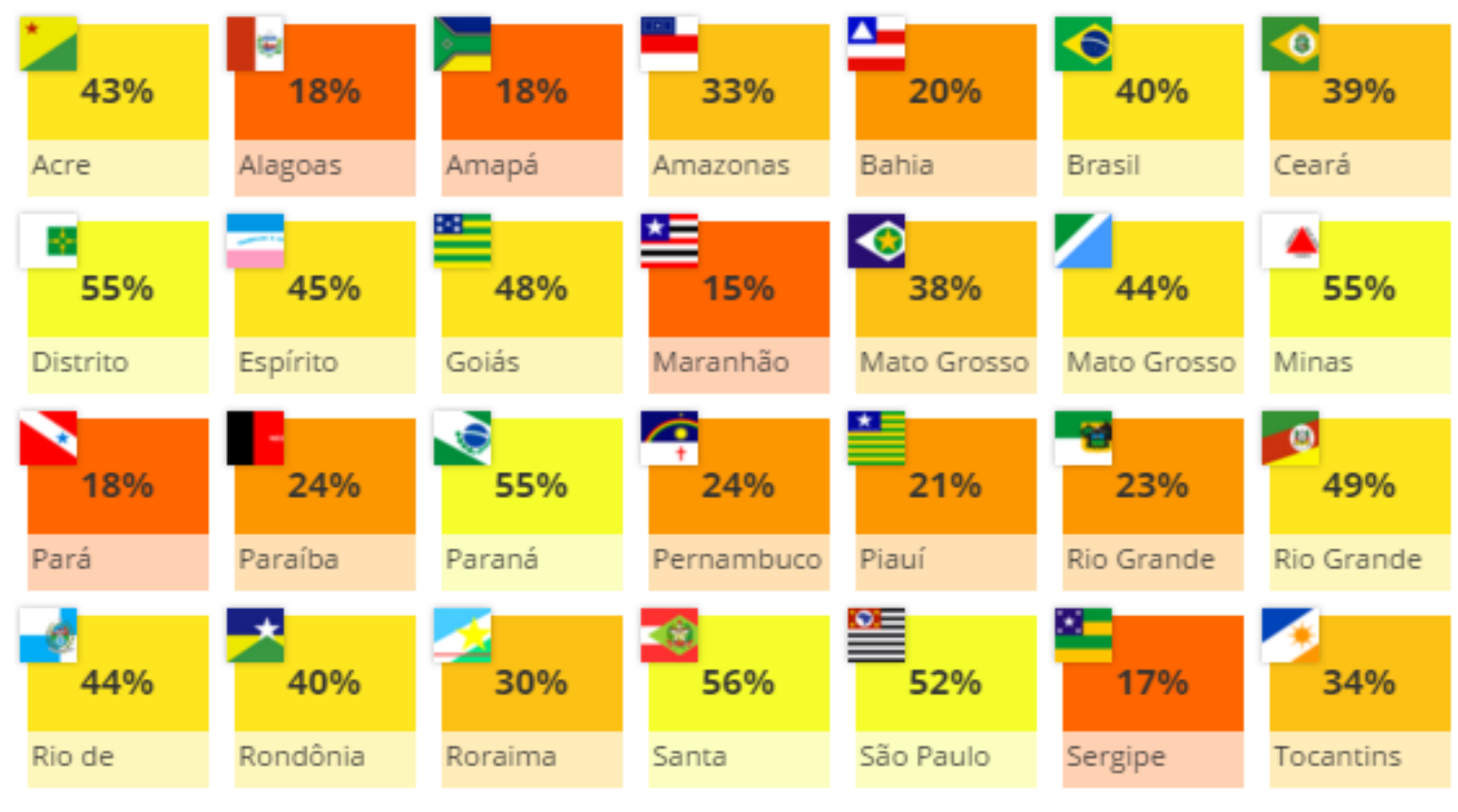

Fonte: Plataforma Qedu, 2013.

Os Estados do Norte e Nordeste concentram os menores percentuais de alunos considerados com aprendizado adequado em Língua Portuguesa na Prova Brasil 2013, assim como a análise dos resultados da ANA exibiram.

Observa-se que os Estados apontados com os menores percentuais de alunos em níveis adequados de aprendizagem em Língua Portuguesa na Prova Brasil 2013, para os anos iniciais, são os mesmos com o menor percentual de alunos no nível 4 de proficiência na ANA, nos anos de 2013 e 2014, sendo: Alagoas, Maranhão Bahia e Amapá. Destaca-se o estado de Alagoas, com 18\% dos alunos com aprendizado considerado adequado na Prova Brasil, um dos menores do país, foi o Estado com o maior percentual de alunos no nível 1, o mais 
elementar, da escala de leitura da ANA 2013, com mais de 50\% dos alunos. Tal percentual se manteve alto em 2014 com 46,79\% dos alunos.

O Estado do Maranhão com o menor percentual de alunos com aprendizado adequado em Língua Portuguesa, na Prova Brasil 2013, apresentou um dos menores percentuais de alunos no nível de proficiência 4 da escala da ANA, com 5\% em 2013 e 4,43\% em 2014.

Os Estados de Minas Gerais, Santa Catarina, Paraná, Distrito Federal e São Paulo, apresentaram os maiores percentuais de alunos com aprendizado considerado adequado em Língua Portuguesa na Prova Brasil 2013, mais de 50\%. Na ANA 2014 os Estados de Minas Gerais, Santa Catarina e São Paulo, também apresentaram os maiores percentuais de alunos no último nível da escala de proficiência em Leitura, com 25,63 \%, 15,77\% e 18,51\%, consecutivamente.

Essa pequena análise indica que os resultados da ANA, tem revelado os mesmos problemas de aprendizagem que já eram demonstrados pelos resultados do SAEB. Os Estados que aparecem com níveis de proficiência mais baixos, são os mesmos em que as escolas possuem os menores IDEB's.

Cumpre esclarecer que a análise apresentada não pretendeu comparar diretamente os resultados das avaliações Prova Brasil e ANA, mas sim, o panorama do diagnóstico de alfabetização dos alunos do ensino fundamental, mesmo diferentes etapas de ensino.

\subsection{ANÁLISE COMPARADA DAS MATRIZES DE REFERÊNCIA DA ANA E DA PROVINHA BRASIL}

\section{a) Concepção de elaboração, seus eixos e descritores}

As Matrizes de Referência da Avaliação da Provinha Brasil elencam os conhecimentos esperados dos alunos após o início do processo de alfabetização em língua portuguesa e matemática. A matriz é apenas uma referência para a construção do instrumento de avaliação.

É, portanto, diferente de uma proposta curricular ou de programas de ensino, que são mais amplos e complexos. (INEP, 2014)

No caso da ANA, as Matrizes de Referência são o recorte de um conjunto delimitado de conhecimentos que as escolas deveriam trabalhar e os estudantes, aprender. Por esta razão, não devem substituir as propostas curriculares de cada sistema ou unidade escolar. (INEP, 2015)

As Matrizes de Referência de ambas as avaliações externas estão baseadas em 
concepções de alfabetização e letramento consideradas na comunidade acadêmica. Entretanto, diferem quanto aos documentos-base utilizados por especialistas para sua estruturação. $\mathrm{Na}$ matriz de referência da Provinha Brasil foram organizadas e descritas competências e habilidades cuja estruturação tomou como base o documento "Pró- Letramento - Programa de Formação Continuada de Professores dos Anos/Séries Iniciais do Ensino Fundamental" e demais orientações que norteiam as avaliações nacionais desenvolvidas pelo INEP. (BRASIL 2014). Já a matriz da ANA teve como principal norteador o documento "Elementos Conceituais e Metodológicos para Definição dos Direitos de Aprendizagem” elaborado pelo MEC, além de documentos oficiais e de formação produzidos no âmbito do PNAIC (INEP, 2013).

Verifica-se que ambas as matrizes são construídas considerando habilidades de alfabetização e letramento agrupadas em Eixos. Porém, a matriz de referência da Provinha Brasil está estruturada a partir dos eixos:

i) Apropriação do Sistema de Escrita que consiste na apropriação, pelo aluno, do sistema alfabético de escrita a partir da compreensão da lógica de funcionamento desse sistema, com a identificação de letras do alfabeto, as diferentes formas de representação gráfica, o reconhecimento de unidades sonoras como fonemas e sílabas e suas representações gráficas, além do reconhecimento das estruturas silábicas das palavras e marcas gráficas que demarcam o início e término de cada palavra escrita (INEP, 2014); e

ii) Leitura que consiste na capacidade do aluno em desenvolver habilidades que the permitam a leitura de palavras e frases, a localização de informações explícitas em frases ou textos, o reconhecimento do assunto e das finalidades dos textos, além do estabelecimento de inferências e relações entre partes do texto. (INEP, 2014).

Já a Matriz de língua portuguesa da ANA está organizada em dois eixos estruturantes: Leitura e Escrita, que abrangem diferentes níveis que vão desde a avaliação da leitura e escrita de palavras até a avaliação da leitura e escrita de textos, incluindo-se um conjunto de conhecimentos e habilidades linguísticas necessárias à proficiência na leitura e na escrita, esperadas para a faixa etária à qual o instrumento se destina. Considera-se que, dentre os conhecimentos e habilidades a serem avaliados, o peso maior está nas habilidades de compreensão e escrita de textos. A matriz foi pensada para que, dentre os conhecimentos e habilidades a serem avaliados, o foco maior estivesse nas habilidades de compreensão e 
escrita de textos, embora também seja avaliado o uso das correspondências som-grafia na leitura e escrita de palavras. (INEP, 2014)

Por mais que a denominação dos seus eixos seja semelhante, eles reúnem descritores e habilidades totalmente diversos. Ressalta-se, ainda, que apesar de considerar, em seus documentos norteadores, a importância do processo de escrita, tais habilidades não são avaliadas nos testes aplicados pela Provinha Brasil por questões técnico-metodológicas (INEP, 2014.). Já a matriz de referência da ANA avalia habilidades de escrita, tanto de palavras quanto de textos. Nesse sentido, o eixo de escrita representa significativo acréscimo de complexidade aos procedimentos de aplicação e correção dos testes da ANA. Assim, permitem a geração de informação qualificada sobre o desempenho dos alunos no uso da linguagem escrita.

Morais critica a inexistência de itens de escrita na Provinha Brasil, no cumprimento de sua função diagnóstica para o auxílio aos professores:

\footnotetext{
Consequentemente, para que a Provinha seja um bom instrumento diagnóstico, que oriente o alfabetizador, não vemos nenhuma razão pedagógica que justifique a exclusão de itens de escrita de palavras (como os que existiram no ano de 2008), nem de itens que mensurem a habilidade de produzir textos escritos. Para sermos mais explícitos, julgamos que nenhum argumento estatístico poderia se sobrepor à finalidade pedagógica do exame. (MORAIS et al., 2012, p.167)
}

No caso da ANA, embora o desenvolvimento da escrita não seja linear, a aplicação de questões de escrita permitem observar padrões em diferentes estágios de desenvolvimento, necessários para um diagnóstico mais detalhado no início da aplicação (INEP, 2015).

As matrizes de referência também diferem quanto à organização das habilidades a serem avaliadas nos testes de desempenho. As matrizes de referência da Provinha Brasil estão organizadas por descritores que, detalhados, especificam o que se espera que os alunos sejam capazes de realizar (SILVA, 2009, p. 5). Soares (2011) define como descritor no campo da avaliação, o detalhamento, em uma Matriz de Referência, de uma competência ou das habilidades que a compõem.

A Matriz de português da Provinha Brasil está organizada em 10 descritores (D), que são os conhecimentos que se espera que os alunos tenham adquirido no processo de alfabetização. Tais competências são posteriormente subdividas em 19 subdescritores que especificam as habilidades necessárias para cada um dos Descritores (D) estabelecidos. Por exemplo, no eixo de Apropriação do sistema de escrita para ser capaz de "D1 - Reconhecer letras" é necessário que os alunos sejam capazes de D1.1 - Diferenciar letras de outros sinais gráficos; D1.2 - Identificar as letras do alfabeto e D1.3 - Identificar diferentes tipos de letras. 
Já a Matriz de português da ANA está organizada na descrição direta das habilidades que devem ser adquiridas em cada um dos eixos estruturantes. São elencadas 12 habilidades (H), tornando-a uma matriz mais enxuta e objetiva. Por exemplo: No eixo de Leitura é avaliada a habilidade H1 - Ler palavras com estrutura silábica canônica.

Outro fator que dificulta a possibilidade de comparação dos resultados das avaliações de alfabetização é a definição, ainda sem consenso entre as habilidades descritas e aquelas que efetivamente estão de acordo com o que se define e aceita internacionalmente como competências que compõe o processo de alfabetização (OLIVEIRA; SILVA, 2011).

Em estudo desenvolvido por Oliveira e Silva (2011) ressalta-se que os testes em alfabetização não avaliam aquilo que se propõe a avaliar. No referido estudo, foram analisados os descritores referentes ao indicador "decodificar palavras" de pelo menos cinco testes de alfabetização existentes no Brasil. A comparação demonstrou que entre os testes de alfabetização avaliados (Provinha Brasil, SPACE, SIMAVE, SAERS e RS) "não existe um consenso a respeito do construto (alfabetizar), nem das competências que permitiriam mensurá-lo (decodificar), nem a respeito das formas adequadas para obter sua medida." (2011, p. 832).

Segundo Bonamino e Sousa (2012), é fundamental explicitar a estrutura conceitual e os critérios utilizados na elaboração dos instrumentos de avaliação do desempenho de alunos. No caso da avaliação envolvendo a leitura e a escrita, torna-se fundamental compreender as noções de alfabetização e letramento subjacentes à avaliação da alfabetização.

\section{b) Entendendo os níveis e escalas de proficiência}

No que tange à ANA, aplicada nos anos de 2013 e 2014, os resultados de desempenho nas áreas avaliadas são expressos em escalas de proficiência. Tais escalas de língua portuguesa (Leitura) e de Matemática são compostas por quatro níveis progressivos e cumulativos, denotando uma organização da menor para a maior proficiência. Metodologicamente, quando um percentual de alunos for posicionado em determinado nível da escala, pode-se pressupor que, além de terem desenvolvido as habilidades referentes a este nível, provavelmente também desenvolveram as habilidades referentes aos níveis anteriores (INEP, 2014)

Já a Provinha Brasil não apresenta seus resultados em escalas de proficiência, mas em níveis determinados pela quantidade de acertos dos alunos nos itens de cada um dos testes, conforme apresentados no Quadro 4 do presente trabalho. São utilizados níveis para cada um 
dos descritores, de modo a indicar graus de complexidade para a habilidade avaliada e a orientar a elaboração de itens que considerem tais especificidades (SILVA, 2009, p. 6). Os alunos são classificados em cada um dos níveis de acordo com a quantidade de acertos nos itens dos testes. Segundo Morais et al. (2012, p. 170) “[...] o que permitiria um aluno ser classificado no penúltimo nível da escala seria, literalmente, o somatório de pontos que obteve, independentemente de onde os acertos ocorreram".

Na construção dos resultados da ANA, é estabelecida escala de interpretação pedagógica. Com base no nível da escala em que os alunos estão situados e com a respectiva interpretação pedagógica desses níveis, é possível inferir as habilidades que os alunos provávelmente dominam, subsidiando, assim, a ação de professores e gestores. Nesse processo, ocorre a divisão da escala em níveis e a definição dos itens âncora ${ }^{5}$ para cada nível. (INEP, 2014)

É expresso em ambas as matrizes que o aluno enquadrado em determinado nível de proficiência provavelmente já domina as habilidades dos níveis anteriores. Porém, os níveis de proficiência da Provinha Brasil não permitem compreender de fato em que condições o aluno apreendeu e domina as habilidades de determinado nível. Observa-se o mesmo problema na matriz de referência da ANA.

Para Morais et al. (2012) a categorização de alunos nos níveis da escala adotada pelo INEP, a cada edição da Provinha, poderia induzir o docente a não analisar, qualitativamente e de modo mais exato, quais conhecimentos ou habilidades cada aluno específico precisaria ser auxiliado a desenvolver, igualando, num mesmo "degrau" da escala, alunos com claras diferenças em seus saberes.

Apesar de ser aplicada em duas etapas do $2^{\circ}$ ano do ciclo de alfabetização, a matriz da Provinha Brasil apresenta habilidades de domínio integral da leitura que posteriormente são aferidos também pela ANA.

A possibilidade de complementação de ambas as avaliações é possível em termos de preparação dos alunos para participarem da ANA. Porém, não é possível a integração de seus resultados, tendo em vista que seus níveis de proficiência estão organizados em escalas diferentes, não permitindo aos professores ou gestores e técnicos das secretarias de educação

\footnotetext{
${ }^{5}$ Cada nível é caracterizado por um conjunto de itens denominados itens âncoras. Os critérios de ancoragem utilizados faz uso da Probabilidade de Resposta Correta (PRC) para alocação dos itens. Nesta metodologia, a PRC de cada item é calculada a partir da proporção empírica de respostas corretas para cada um dos níveis e define-se em $65 \%$ o valor percentual de acerto necessário para que esse item seja definido como item âncora para um determinado nível. Se um item é considerado fácil, ele demanda menor proficiência para sua resolução e o valor da PRC atinge 65\%, logo está localizado nos pontos mais baixos da escala; por outro lado, se o item é considerado difícil, ele demanda maior proficiência para sua resolução e, portanto, fica alocado em pontos mais altos da escala) (NT Inep 2014)
} 
estaduais e municipais, tal correspondência.

Os resultados da ANA são apresentados por escola, enquanto os resultados da Provinha Brasil podem ser apresentados por aluno. O que demonstra mais uma dificuldade de integração de tais resultados, tendo em vista não ser possível, no caso da ANA, a identificação do aluno e sua evolução a partir das avaliações aplicadas no $2^{\circ}$ ano.

\subsection{PERCEPÇÕES DE ESPECIALISTAS EM AVALIAÇÕES EDUCACIONAIS}

No grupo focal, os servidores do Inep, perguntados acerca do que conheciam sobre o Pacto Nacional de Alfabetização na Idade Certa, PNAIC alguns participantes do grupo relataram ter conhecimento sobre a política e levantaram uma crítica ao Programa, considerando-o uma política de governo e não uma política de Estado:

Esse é um governo que não tem uma política de estado para a educação e que governa por programas. Então, mais uma vez, o Pacto é um programa que [...] pode nascer e morrer muito facilmente, mas que engendra uma série de ações e uma série de responsabilidades para diversos órgãos, como o nosso que acabou tendo que assumir uma série de coisas que não dialogam com o que a gente faz. Ele é bastante eficiente pelo que a gente pode perceber, mas ele também vem cumprir uma função que tinha que estar na formação de professores. Os professores tinham que sair da graduação com alguma formação em metodologia de ensino em língua portuguesa, em alfabetização. (Participante 2)

Nesse contexto, foi relatado, ainda, que o Pacto vem cumprir uma função que deveria ser dos cursos de formação para professores e ao invés de se corrigir falhas na formação inicial dos docentes, cria-se um curso de formação continuada de professores para atender a quem já está atuando. Há estudos tem demonstrado a distorção entre a formação docente e a prática das disciplinas que ministram e é premente uma revisão dos currículos dos cursos de educação superior para que as lacunas na formação sejam superadas e os professores estejam, de fato, preparados para as salas de aula.

Além disso, foi apontado que o PNAIC oferece poucos insumos para a efetivação de suas ações e muita cobrança por resultados. A percepção do grupo é que o programa se espelhou em outras políticas como PAIC no Ceará, mas também é fruto de todas as outras políticas do MEC e que nasce com um problema sério que é a falta de currículo, de uma base de educação comum para o País e que passa a ser definida pela matriz da ANA.

“[...] O Pacto vem com um problema sério que é, bom, a gente não tem um currículo a gente não tem uma base nacional comum. Alguém precisava definir o que o aluno 
precisa saber. É uma política do MEC, que não assume que está criando um currículo, mas cria um programa... então há uma série de desarticulações aí. Porque fazer uma avaliação como essa não é uma avaliar o Pacto. Não é uma avaliação de programa, é uma avaliação de produto porque o Pacto não atinge todos os municípios e a gente avaliar todos os municípios."

Importante ressaltar que a ANA por ser aplicada ao final do ciclo de alfabetização é a avaliação de um produto de aprendizagem, um retrato daquele momento específico. Não pode ser considerada uma avaliação do PNAIC, pois ele é de adesão voluntária e a ANA é aplicada obrigatoriamente a todas as escolas públicas com alunos matriculados no $3^{\circ}$ ano do ensino fundamental. Também não é o único pilar de sustentação do programa que conta com a formação docente, aqui já mencionada, como uma de seus principais eixos.

Ainda sobre as distorções no processo de implementação da ANA o grupo alertou para o diagnóstico da alfabetização que já era produzido pelo SAEB, ao demonstrar que no $5^{\circ}$ ano do ensino fundamental, os alunos não haviam dominado as habilidades elementares do processo de alfabetização e isso se refletiria, obviamente nos resultados da ANA:

Em 2012 quando o Pacto foi lançado, o INEP recebeu algumas demandas entre elas
foi o sistema da Provinha Brasil, atendeu, e a outra demanda foi a ANA [...] e
avaliação da nossa coordenação era de que ela não era uma avaliação necessária [...]
primeiro porque a gente já tinha o Saeb e a Prova Brasil desde 2005 , então a gente já
tinha dados mostrando que em 2011 , por exemplo [...] $25 \%$ dos meninos estão no
nível zero e no nível um da escala de leitura. Então, se no $5^{\circ}$ ano eles não sabem as
habilidades básicas da escala de leitura, no $3^{\circ}$ ano eles também não vão saber. A
gente não precisava fazer uma avaliação censitária para chegar a essa conclusão.
(participante 6 )

Não foi necessário introduzir a pergunta a respeito da percepção dos participantes acerca da ANA. Dentre as falas dos participantes, destaca-se a questão: "Pra que ANA se já tem Provinha Brasil?” (participante 5). O debate transcorreu com a concordância no grupo de que A ANA é uma avaliação melhor que a Provinha Brasil, pois é composta por uma matriz mais enxuta; e de que a Provinha é uma avaliação muito bem vista, externamente:

\footnotetext{
Os itens da ANA são melhores que os itens da Provinha, a avaliação inteira é melhor do ponto de vista do construto que elas propõe avaliar, ela tem muitos limites porque o instrumento tem muitos limites, mas ela é fruto de uma equipe que concebeu a Provinha, que conhecia todos os limites, que conhecia todos os problemas e que avançou. [...] Ela mede uma coisa mais interessante que é o letramento escolar à medida que você pode avaliar isso por meio de um instrumento. (Participante 2)
}

Uma das hipóteses apontadas para isso é o fato de ser uma avaliação que o INEP não controla, utilizada pelas escolas como um instrumento diagnóstico. Mas do ponto de vista da matriz, ela ainda é uma avaliação muito frágil, com uma série de limitações que foram 
superadas na ANA. O grupo também levantou a questão sobre a necessidade de criação de uma nova avaliação quando a Provinha Brasil poderia ser melhorada.

\footnotetext{
"Para a área a Provinha como construto, ela é ruim, com uma estratégia muito boa diante de uma avaliação que o Inep se propõe a fazer. A ANA é o contrário, ela tem uma matriz que é boa, tem itens que são bons e mede coisas interessantes, mas vem reforçar o sistema de controle." (participante 2).
}

Sob esse aspecto é importante ressaltar que as avaliações muitas vezes assumem a conotação de controle, fruto do estado regulador que se consolidou após as reformas do aparelho estatal na busca pela eficiência dos serviços públicos. Em alguma medida, ao avaliar os alunos, as escolas, as redes de ensino, o Governo Federal assume esse papel de estado avaliador. Nesse sentido, na fala do participante 4, foi apontado um elemento importante sobre o objetivo das avaliações que obteve a concordância de todo o grupo:

Pensando na concepção geral de avaliação, [...] a ideia da avaliação externa é introduzir no debate educacional o conceito de responsabilização. E essa responsabilização, apostando nela como um estímulo para mobilizar tanto o governo quanto a sociedade e escolas, só que nesse percurso tem várias distorções.

Observa-se que o controle produzido pelo Estado gera a expectativa pela responsabilização dos entes subnacionais, das escolas e principalmente dos professores que são elementares no processo de ensino e aprendizagem, mas que não tem sob si a responsabilidade total pelo sucesso ou fracasso dos alunos, à medida que diversos fatores contribuem para a aprendizagem e devem também ser avaliados na construção de um diagnóstico da educação do país.

Assim, foi relatado pelo grupo, que o INEP fugiu da ideia de que a ANA fosse só um teste. "Mais do que dizer o que a criança aprendeu ou deixou de aprender, a gente tem que dizer em que condições ela fez isso" (participante 2). Porém, o trabalho de concepção dessa nova avaliação, foi realizado de forma inadequada. Foi equânime que não houve o planejamento e o tempo necessários para a produção da avaliação. Nesse sentido, surgiu a preocupação com os objetivos dessas ações sem planejamento que envolvem recursos públicos e a realização de uma avaliação que não foi pensada nem concebida adequadamente, simplesmente para atender a uma política de governo:

“[...] Alguns fatores a gente costuma dissociar da questão metodológica e que tem a ver, como, por exemplo, o orçamento. As ações que a gente venha a propor tem que ter coerência com o objetivo a ser alcançado porque a gente tá lidando com recurso público, o valor de uma avaliação dessas, muitas vezes, é o orçamento de um órgão. [...] A gente gasta um valor milionário, para atender a uma política de governo e se o 
governo sai ficam duas dívidas, a financeira e a social” (participante 3)

Importante ressaltar que os custos para a aplicação de avaliações em larga escala, como, a ANA são altíssimos e envolvem uma estrutura logística de aplicação muito grande, com a mobilização de milhares de pessoas e a terceirização dos serviços de aplicação, exigindo um alto grau de controle e acompanhamento na coleta e processamento das informações.

O grupo revelou, também, a preocupação com os resultados produzidos pela ANA. O tempo levado para a execução, criação de sistemas e indicadores da avaliação foi de apenas 8 meses e estimou que seriam necessários pelo menos dois anos para a conceber uma avaliação como essa de forma adequada, obedecendo a todas as etapas de concepção, elaboração de itens, pré-testagem, calibragem de escalas e contratação, tudo o que terá impacto nos resultados produzidos, posteriormente, pela avaliação:

Evidencia-se pela discussão do grupo que a falta de recursos e de tempo técnico para a realização da ANA prejudicou a qualidade do dado a ser fornecido. Como um dos problemas apontados, a incerteza de que alguns resultados reflitam a falta de conhecimento dos alunos ou foram causados por problemas de aplicação. Como exemplo dado, $25 \%$ das crianças não responderam à prova de escrita e o motivo é desconhecido, conforme relatado:

\footnotetext{
Um volume muito grande de crianças que não responderam a prova de escrita e esses dados não estão indo para o público porque eu não tenho como saber se foi um problema de aplicação ou se as crianças realmente não sabiam responder. (participante 2)
}

Foi apontada, ainda, a importância de pensar nas avaliações que os estados já aplicam e na prova $\mathrm{ABC}$, aplicada pelo Todos pela Educação. "Você já tem um campo da avaliação do $3^{\circ}$ ano constituído e eu tenho curiosidade de saber em que medida a ANA dialoga com essas outras avaliações ou não dialoga?" (participante 4). O debate seguiu na linha de que as avaliações dos estados dialogam mais com a ANA na medida em que os resultados não diferem muito e em alguns estados já há propostas no sentido de abandonar suas avaliações para utilizar os dados da ANA.

Falta uma compreensão, pensando nas escolas, o que realmente essa avaliação está medindo para a escola? [...] Ninguém tem muito claro [...] pra que serve essa avaliação externa? A impressão que dá é que eles leem a avaliação externa com os olhos da avaliação de aprendizagem (participante 4).

Foi consenso no grupo que, da maneira como foi concebida, a avaliação serve como diagnóstico de políticas públicas, mas poderia ser amostral, não ter essa periodicidade porque 
tem limites por ser universal como a impossibilidade de cálculo e divulgação de resultados. "[...] a gente recebeu recursos de várias escolas que fizeram a ANA [...] meus alunos fizeram, mobilizei minha escola [...] mas a senhora não tem resultado" (participante 1)

Além do tempo curto para a realização da avaliação, existe a preocupação com a realização dessa análise anualmente, já que isso não é necessário em verificações externas. $\mathrm{Na}$ opinião do grupo, é um custo muito alto do processo para não haver mudanças nos resultados. Não adianta julgar, se os resultados serão os mesmos. Sendo assim, a ANA realizada anualmente passa a reforçar, mais uma vez, o instrumento de controle.

Por fim, com relação à ANA como instrumento de controle e realizada anualmente, o mediador questionou em que medida a avaliação seria um instrumento de gestão. Para o grupo, a ANA não é um instrumento de gestão do Pacto por ter nascido praticamente junto com o programa e devido à sua periodicidade, além de não avaliar os mesmos municípios que aderiram ao Pacto. Nesse sentido, é apontada como uma linha de base, "no máximo como ponto de partida" (participante 6). "Se o intervalo fosse maior, você aplica em 2013, pra ter essa base, depois você aplica daqui a dois anos pra ver o que avançou, depois aplica novamente $[\ldots]$ ".. (participante 1$)$.

Houve a concordância no grupo de que, se a avaliação tivesse outra periodicidade, com certeza seria um instrumento de gestão. A ANA tem essa lógica de ser um reorientador da política e inclusive o material de formação deveria ser produzido a partir dessa base, porém "ela nasce como um adendo" (participante 2).

Ressalta-se que os resultados desta técnica de pesquisa apresentada foram substanciais para a pesquisa e contribuíram também para a formatação do roteiro de entrevista semiestruturado a ser aplicado aos interlocutores estaduais junto ao INEP para a coleta da percepção dos mesmos sobre as possibilidades de uso da ANA e da Provinha Brasil nas políticas desenvolvidas pelos estados, bem como na construção de um diagnóstico de alfabetização. 


\subsection{COMO OS RESULTADOS DA ANA SÃO UTILIZADOS PELOS GESTORES ESTADUAIS DE EDUCAÇÃO}

Os interlocutores são caracterizados na presente pesquisa como informantes-chave e estão citados como INT I, II, III, IV, V e VI sem que isso tenha qualquer relação com a ordem dos estados selecionados. As primeiras perguntas realizadas nas entrevistas foram sobre o perfil profissional dos interlocutores e os resultados estão sintetizados abaixo:

Quadro 13 - Perfil dos entrevistados

\begin{tabular}{|c|c|c|c|c|}
\hline Interlocutor & Sexo & Formação & Cargo na Secretaria & $\begin{array}{c}\text { Experiência } \\
\text { anterior }\end{array}$ \\
\hline INT_I & $\mathrm{F}$ & $\begin{array}{c}\text { Graduação em Letras } \\
\text { (licenciatura) } \\
\text { Gestão Pública } \\
\text { (2ª graduação) }\end{array}$ & $\begin{array}{l}\text { Coordenadora estadual do Censo } \\
\text { Escolar }\end{array}$ & $\begin{array}{l}\text { Professora } \\
\text { (3 anos) } \\
\text { Técnico em } \\
\text { assuntos } \\
\text { educacionais }\end{array}$ \\
\hline INT_II & $\mathrm{F}$ & $\begin{array}{c}\text { Graduação em } \\
\text { Pedagogia } \\
\text { Pós Graduação em } \\
\text { consultoria pedagógica } \\
\text { Mestre em ciências da } \\
\text { educação }\end{array}$ & $\begin{array}{l}\text { Coordenadora do Núcleo de } \\
\text { estudo, pesquisas em avaliação e } \\
\text { currículo. NEPAC }\end{array}$ & $\begin{array}{l}\text { Professora } \\
\text { Coordenadora } \\
\text { pedagógica }\end{array}$ \\
\hline INT_III & $\mathrm{M}$ & $\begin{array}{l}\text { Licenciatura em } \\
\text { Matemática } \\
\text { Pós Graduação em } \\
\text { Psicopedagogia }\end{array}$ & Técnico em pesquisas educacionais & $\begin{array}{l}\text { Professor } \\
(12 \text { anos })\end{array}$ \\
\hline INT_IV & $\mathrm{F}$ & $\begin{array}{l}\text { Pedagoga } \\
\text { Especialização em } \\
\text { Didática geral }\end{array}$ & $\begin{array}{c}\text { Assessora técnica pedagógica do } \\
\text { currículo }\end{array}$ & $\begin{array}{l}\text { Professora } \\
(26 \text { anos })\end{array}$ \\
\hline INT_V & $\mathrm{F}$ & Pedagogia & Núcleo de Avaliação & Professora \\
\hline INT_VI & M & $\begin{array}{l}\text { Graduação em Letras } \\
\text { Pós Graduação em } \\
\text { Leitura e Produção de } \\
\text { Textos }\end{array}$ & $\begin{array}{c}\text { Subcoordenador de Avaliação } \\
\text { Educacional }\end{array}$ & $\begin{array}{l}\text { Técnico de } \\
\text { assessoramento } \\
\text { pedagógico }\end{array}$ \\
\hline
\end{tabular}

Fonte: Elaboração própria

Com relação às atividades desenvolvidas na função de interlocutores, junto ao INEP, cujas atribuições estão expressas em Portaria, os interlocutores relataram que desenvolvem atividades de acordo com o Quadro 14, a seguir: 
Quadro 14 - Atividades na função de interlocutor

\begin{tabular}{|c|c|c|}
\hline Interlocutor & Tempo na função & Atividade desempenhada \\
\hline INT_I & Desde 2007 & $\begin{array}{l}\text { - } \quad \text { Coordenação do SAEB desde } 2007 \\
\text { - } \text { Disseminação da cultura de avaliação no estado } \\
\text { e interlocução do INEP no estado. } \\
\text { - Levar conhecimento aos envolvidos no processo } \\
\text { e levar as pessoas a se apropriarem das ações } \\
\text { que o INEP realiza, não só na rede estadual, mas } \\
\text { nos municípios também. } \\
\text { - Convocação dos municípios para adesão à } \\
\text { Provinha Brasil e Pisa. }\end{array}$ \\
\hline INT_II & Desde 1991 & $\begin{array}{l}\text { - Análise dos resultados das avaliações } \\
\text { - Diagnóstico pedagógico em nível de rede } \\
\text { estadual } \\
\text { - Envio para o departamento de Educação Básica. } \\
\text { - Coordenadora estadual de logística do SAEB } \\
\text { - Apoio nas aplicações do BNI e da ANA. }\end{array}$ \\
\hline INT_III & Desde 2015 & $\begin{array}{l}\text { - Interlocução junto ao IINEP nos trabalhos sobre } \\
\text { avaliação }\end{array}$ \\
\hline INT_IV & Desde 2015 & $\begin{array}{l}\text { - Coordenação do PNAIC e interlocução junto } \\
\text { aos coordenadores nos municípios. } \\
\text { - Orientação, disseminação de resultados }\end{array}$ \\
\hline INT_V & Desde 2015 & $\begin{array}{l}\text { - Disseminação das informações de avaliação } \\
\text { - Acompanhamento do SAEB }\end{array}$ \\
\hline INT_VI & Desde 2009 & $\begin{array}{l}\text { - Interlocução junto ao INEP e acompanhamento } \\
\text { das redes }\end{array}$ \\
\hline
\end{tabular}

Fonte: Elaboração própria (2015)

a) Aplicação e sistematização de dados

Ao questionar os interlocutores a respeito da aplicação da Provinha Brasil e da ANA em seus estados nos anos de 2013 e 2014, todos declararam ter havido aplicação. Porém, o INT_I ressaltou o fim dos anos iniciais do ensino fundamental na rede estadual de ensino e que a aplicação foi realizada apenas para as turmas que compõem a rede municipal de educação:

Praticamente estamos acabando com os anos iniciais do ensino fundamental da rede estadual. Mas a rede municipal, eles fazem a aplicação da Provinha Brasil como se fosse uma pré-avaliação. Para identificar as dificuldades da criança e trabalhar essas dificuldades para que quando da avaliação da ANA, eles não sintam dificuldade. Inclusive passou na TV as crianças respondendo a Provinha Brasil e eu fiquei até preocupada, mas eles falaram que ela não tinha o objetivo de avaliar e sim de diagnosticar. 
Com a descentralização do sistema educacional, verifica-se, cada vez mais, a municipalização da oferta nos três primeiros anos do ensino fundamental. Por isso, a necessidade de apropriação, por parte dos gestores municipais de educação, dos resultados das avaliações externas que são aplicadas durante o ciclo de alfabetização, tendo em vista ser o município, nessa conjuntura, o principal responsável e interessado pelos insumos que as avaliações fornecem. Além disso, depreende-se da afirmação do INT_I, a utilização da Provinha Brasil como "avaliação preparatória" para a participação dos alunos na ANA, no ano seguinte. Nessa perspectiva, o INT_I completa:

Eu tenho uma vaga impressão que esse processo de aplicação da Provinha Brasil
está trazendo aquela responsabilidade [...] ela é uma provinha diagnóstica. Ela não
tem o cunho de avaliar. Então de tanto eles começarem a aplicar e já tomando essa
conotação de preparação para a ANA em 2016, a gente já identificou que houve uma
melhora. Nós estamos curiosos para saber em 2016 [...] o resultado. Porque a gente
vê o envolvimento de toda a rede municipal, tanto agora na aplicação da Prova
Brasil quanto do BNI, eles vestem mesmo a camisa e as escolas se preparam mesmo
para esse processo de avaliação.

Em 2013, verificou-se a iniciativa do INEP em desenvolver um sistema de coleta de dados da Provinha Brasil, atendendo à diretriz do PNAIC que estabelece que "os professores terão acesso a um sistema informatizado onde deverão inserir os resultados da Provinha Brasil de cada criança, no início e no final do $2^{\circ}$ ano". Através deste sistema, docentes e gestores poderiam acompanhar o desenvolvimento da aprendizagem de cada aluno de sua turma e fazer os ajustes necessários para garantir que todos estejam alfabetizados no final do $3^{\circ}$ ano do ensino fundamental. Porém, o desenvolvimento desse Sistema não logrou êxito, apenas a expectativa nas redes de ensino municipais e estaduais de que teriam os resultados da avaliação consolidados eletronicamente.

Dessa forma, os interlocutores foram questionados se as Secretarias de Educação de seus estados dispunham de um sistema próprio de coleta dos dados da Provinha Brasil e de que forma esses resultados eram consolidados. O INT_IV afirmou que sua Secretaria, apesar de não ter um Sistema próprio de avaliação educacional institucionalizado, dispõe de sistema de coleta de dados da Provinha Brasil, destacando sua importância:

A gente não tem sistema próprio de avaliação. Mas no caso da Provinha Brasil a gente criou um sistema onde a gente consegue ter um feedback desses resultados por escola, por aluno e pela rede como um todo. A gente criou um sistema de utilização e apropriação pedagógica desses resultados. Um sistema via SIGA, sistema acadêmico. [...] a gente faz a aplicação do material e o coordenador pedagógico de cada escola, ele que aplica e faz a inserção nesse sistema. E aí esse sistema devolve para as escolas esses resultados analisados, em forma de gráficos, relatórios, o resultado da escola por turma e por aluno. 
Porém, há Secretarias de Educação que não dispõem de sistemas de coleta dos dados de aplicação da Provinha Brasil e, nesses casos é necessário que desenvolvam formas mais simplificadas de cálculo e consolidação dessas informações. Nessa perspectiva, o INT_IV destacou, ainda, a dificuldade das redes municipais de seu estado em calcular os resultados da Provinha Brasil, diferente dos gestores da Rede Estadual que dispõe de um sistema que estrutura esses dados:

Sistema próprio não, o que nós trabalhamos é um arquivo em Excel que se lançam as notas das escolas e a gente tira uma média e estabelece o nível, entendeu? Mas não é um sistema. A Secretaria que utiliza para verificar a rede, em termos de rendimento dos níveis das escolas da rede. Exatamente, como vem a ficha de correção para nós. (INT_III)

O próprio sistema nos dá a porcentagem pelos níveis, então a gente consegue tirar por escola como está a quantidade de alunos por nível, por escola, por município, por CEFAPRO e também a nível de estado. No município eles ficam desesperados. Como que a gente faz? Nós não temos... Mas a gente tá sempre orientando, conversando com eles, "vocês não tem o sistema do INEP, mas vocês podem ter o de vocês, até mesmo manual". Porque a aplicação é uma etapa, mas o importante é que vocês peguem essas informações e façam manual. A gente tem orientado e feito um trabalho bem legal com os municípios. (INT_IV)

Evidencia-se, nos relatos dos interlocutores, a importância do desenvolvimento de um sistema que possibilite a consolidação e apresentação dos resultados da Provinha Brasil para uma melhor compreensão dos gestores e das escolas, inclusive, professores, sobre como trabalhar tais resultados. A dificuldade em manipular os dados dá aos gestores e escolas uma visão reducionista de seu uso, como apenas o cálculo das médias dos alunos, ou acaba desmotivando o trabalho, pois os dados não são compreendidos e, portanto, acabam não sendo traduzidos em ações.

Observou-se que os estados que possuem sistemas bem estruturados para consolidação dos resultados da Provinha Brasil possibilitam a disponibilização e geração de informações qualitativas acerca do desempenho dos alunos para escolas e professores, que vão além da divulgação das médias. A partir de tais resultados, docentes e gestores podem desenvolver estratégicas pedagógicas de intervenção nas práticas de ensino e aprendizagem dos alunos. Com relação à aplicação das provas, correção e cálculo dos resultados que podem ser realizados pelos próprios professores, os interlocutores também destacaram a preocupação com a fidedignidade dos dados e a importância de um sistema que faça a gestão dessas informações. Os interlocutores INT_VI e INT_I declaram: 
Pelo sistema da Provinha, a gente consegue com um clique ver o mapa de tudo como está, o estado como um todo, cada regional, cada município, separado por rede estadual e municipal. O que a gente percebe é que há realmente fidedignidade da parte das informações. Porque quando a gente desenvolveu o sistema foi realmente porque não havia tanta fidedignidade com aquele instrumento, daquele gabarito que o professor preenchia. Porque quando o professor percebia que o resultado não estava bom, ele não queria ficar com o filme queimado e isso induzia.

b) Apropriação e divulgação de resultados

Importante destacar que os resultados da Provinha Brasil podem ser disponibilizados por aluno, o que também favorece o acompanhamento e a identificação das fragilidades de cada um no processo de consolidação da alfabetização. No caso da ANA, os resultados são divulgados pelo INEP, estratificados por UF, município e escola. Podem ser acessados diretamente por seus gestores, porém, os interlocutores também recebem as planilhas com os resultados de todo o estado. Foram então questionados a respeito de como foi feita a divulgação dos resultados da ANA aplicada em 2013 e em 2014. O ITN_VI declarou:

A ANA já tem a sistemática do próprio INEP, quando ele disponibiliza pra gente o planilhão, que agora também vem com a estratificação por níveis e o próprio acesso aos sistema, que continua sendo uma grande dificuldade que as escolas tem. Quando elas acessam através da senha do gestor, muitas delas tem uma grande dificuldade. E como nós não temos uma grande cultura focada nas questões de trabalhar os dados das avaliações, então, geralmente há muita reclamação porque não conseguem e acabam perdendo a motivação por conta dessa dificuldade. Então isso acaba motivando a gente pra fazer encontro com eles realmente e repassar alguns dados sobre consulta diretamente pra gente. Em geral nós temos tido a preocupação de trabalhar, quando a gente se reúne com as equipes pedagógicas das escolas e isso envolve também representantes das secretarias municipais, a gente trabalha tanto a ideia do sistema da Provinha, como o uso dos resultados, na função mesmo de diagnóstico e os resultados da ANA e as matrizes, tanto da ANA como da Provinha, que são muito parecidas... E a gente procura fazer uma discussão do uso pedagógico disso. Do diálogo dessas matrizes com o currículo. E a discussão realmente sobre a necessidade de alfabetizar mesmo.

De que forma esses resultados são divulgados à comunidade escolar e aos profissionais das escolas foi destacado pelo INT_II que:

Os resultados da ANA, a gente faz um mapeamento com os boletins pedagógicos por escola, com o documento orientador e no portal da Secretaria. A gente criou um banner do Saeb, nesse banner, os resultados recebem um tratamento por rede. Além da nossa rede ele sai por diretoria, por escola, com uma análise e também para os municípios, a gente faz esse trabalho também conjunto com os municípios. Faz um tratamento para divulgação no portal da Secretaria de Estado e Educação como também faz oficinas de apropriação. A única avaliação externa que a gente consegue ter resultado por aluno é a Provinha Brasil. [...] já que a gente não tem o sistema estadual de avaliação, a gente não consegue ter esse feedback por aluno. 
O INT_IV também destacou o desenvolvimento de um sistema próprio de divulgação dos resultados que tem ajudado as escolas a se localizarem e a compreender melhor o que os resultados querem dizer e desenvolverem ações de intervenção na realidade escolar, como se verifica do fragmento a seguir:

As escolas acessam a gente tem os relatórios do SIGAI que é um sistema nosso aqui
que ele migra para esse BI os níveis. Então quando você quer saber (em determinada
escola) quantos alunos estão no nível 1? Então as escolas conseguem acessar, as
diretorias, então é liberado geral. A mesma visualização é liberada para todos. E eles
procuram os resultados da Provinha, da ANA, da Prova Brasil para ajudar nas
intervenções. Então eles buscam os resultados, eles têm o diagnóstico e a partir
desse diagnóstico, usam para as intervenções.

Foi destacado que os resultados da Provinha Brasil, por serem disponibilizados por aluno, permitem maior grau de intervenção por parte das secretarias e nos trabalhos desenvolvidos junto às escolas. No caso da ANA, os resultados somente são divulgados segundo cada escola e estas ainda têm dificuldade em acessar o site do INEP para verificar seus resultados:

Quando você fala, veja no site do INEP, quando você fala assim, eles parecem que não conseguem acessar e visualizar com facilidade. Mas quando você pega o link direto, então facilita. [...] no site da Seduc, no próprio site tem os banners do lado direito. A gente colocou avaliações externas e quando a pessoa clica em avaliações externas ela vai conseguir entrar em links de orientações, planilhas relacionadas à Prova Brasil, relacionada à Provinha, relacionada à ANA. Uma forma de divulgar né? (INT_IV)

Nesse sentido, destaca-se a importância do trabalho desenvolvido pelas Secretarias de Educação em manipularem esses dados, tornando os resultados mais acessíveis e de melhor compreensão.

Além das respostas específicas acerca da divulgação dos resultados da ANA e da Provinha Brasil, foi recorrente na fala dos interlocutores a menção aos resultados do SAEB, mais precisamente os resultados da Prova Brasil. Nesse sentido, destaca-se a utilização, por parte dos interlocutores, gestores estaduais e municipais de educação e das próprias escolas, da plataforma QEdu, um portal que sistematiza os dados das avaliações e produz informações qualitativas sobre esses resultados.

A iniciativa foi reconhecida pelo INEP como uma proposta inovadora para a avaliação em educação básica: "um portal no qual o público irá encontrar informações sobre a qualidade do aprendizado em cada escola, município e estado do Brasil (INEP, 2015)”.

Porém, é preciso que o próprio INEP e as instâncias estaduais e municipais de educação também criem mecanismos mais eficientes de manipulação e apropriação desses dados, transformando-os em informações que subsidiem a adoção de ações, programas e políticas. 
O INEP lançou em 2014 a Plataforma "Devolutivas Pedagógicas", que apresenta os itens da Prova Brasil comentados, facilitando a apropriação por professores e gestores dos resultados da avaliação externa. A Plataforma Devolutivas Pedagógicas das Avaliações aproxima as avaliações externas de larga escala ao contexto escolar, tornando mais relevantes as informações das avaliações para o aprendizado dos estudantes (INEP, 2015). É importante que a plataforma Devolutivas Pedagógicas evolua, juntamente com o Sistema da Provinha Brasil, produzindo a integração das informações relativas também à alfabetização, como relatou um dos entrevistados: "Acredito que a gente tenha que ter um momento com vocês, até pra gente entender essa plataforma, como fazer uso dela e para que os professores tenham mais uma ferramenta para fazer seu planejamento e suas intervenções.” (INT_II)

c) Impacto nas políticas educacionais e formação de professores

Os interlocutores foram questionados de que maneira os resultados da ANA e da Provinha Brasil influenciam na política educacional do estado. Os interlocutores IV e V se manifestaram com as seguintes declarações:

Hoje basicamente a gente conta com essas avaliações já que o Estado não tem um
sistema próprio de avaliação. Então é a partir desses resultados que a gente tem
organizado, por exemplo, esse programa Novas Oportunidades de Aprendizagem,
que a gente localiza algumas escolas que tem maiores dificuldades em relação ao à
aprendizagem dos alunos. Então a gente consegue por esses resultados mapear essas
escolas e dar uma orientação diferenciada. (INT_V)
Quando a gente pega um resultado tão negativo, de uma escola, de um município e
até mesmo do Estado, isso ajuda na revisão e no desencademento de ações mesmo
[...] Então, da ANA, o que nós fizemos, nós pegamos 2013 , nós pegamos 2014 e a
partir desses resultados a Secretaria disponibiliza para as escolas, para as Diretorias,
CEFAPROS, e a partir daí, eles fazem as intervenções pedagógicas. Nós temos, por
exemplo, o nosso professor articulador, que é o professor que trabalha com apoio
pedagógico das crianças com desafio de aprendizagem [...] Para eles elaborarem o
plano de ação, o plano de trabalho. Para eles terem esse articulador, eles tinham que
buscar também informações, esse diagnóstico na ANA, na Provinha, nas avaliações
externas para ele poder elaborar esse plano de trabalho de apoio pedagógico e aí a
gente ia analisar enquanto Secretaria e liberar esse profissional. (INT_IV)

Foi possível verificar que as ações educacionais desenvolvidas a partir dos resultados das avaliações vinculam-se principalmente a estratégias pedagógicas, com a disponibilização de multiplicadores e profissionais que auxiliam na intervenção junto à escolas e professores, além de formação específica e continuada para docente das turmas do primeiro ciclo. Destacase na percepção dos interlocutores a forte ligação dos resultados das avaliações de alfabetização, com as políticas desenvolvidas pelo PNAIC. O INT_II descreveu tal relação: 
Os resultados da ANA tem estreita relação com o Pacto de Alfabetização na Idade Certa o PNAIC. As ações do PNAIC elas estão relacionadas também com esses resultados da ANA. Claro que a ANA não avalia o Pacto, mas ela traz pra gente um indicador de que se esse pacto, se essa formação em serviço que está sendo oferecida aos professores, se isso está tendo algum tipo de impacto na formação desses alunos, e consequentemente na melhoria desses resultados. Então como a gente tem a parceria junto com a Universidade Federal, agora no mês de janeiro a gente vai ta fazendo um balanço na verdade, eu vou tá entrando nessa parte, focando na avaliação dos resultados da ANA da rede estadual e da Provinha porque são avaliações que estão dentro do bloco de alfabetização. Então há essa relação, essa preocupação, se de fato a alfabetização, o letramento em leitura e matemática está avançando.

Nessa perspectiva, o PNAIC também agrega ações de formação continuada e de disponibilização de material didático para as escolas, orientações específicas sobre a melhor forma de utilizá-los e na percepção dos interlocutores já é possível perceber os ganhos nas turmas em que os professores participam das formações específicas para o Pacto:

[...] Ela disse que está encantada com o material, com a formação. E os próprios professores percebem, como eu disse, a gente não tem um acompanhamento contínuo desse trabalho. Mas há nos relatos das orientadoras, nos relatos dos próprios professores, a postura, a identidade profissional tem mudado ate mesmo a questão do planejamento coletivo que não era, então a metodologia, a preocupação de fazer diferente, buscar desenvolver o desejo do aluno porque se o aluno não tiver desejo, ele não vai conseguir aprender. O Pnaic proporciona através das suas atividades lúdicas ne'. A matemática, muitos professores que as vezes não conseguiam trabalhar a matemática de forma lúdica, conforme a idade $\mathrm{e}$ desenvolvimento do aluno. Tratava mat. Como se estivesse trabalhando como adulto e não como crianças de 6 a 8 anos. Então a gente percebeu sim a melhoria. Quem está na formação se apaixona. (INT_IV)

Nas turmas das escolas onde os professores participam da formação a gente vê um resultado, um resultado diferenciado, uma melhoria. Não ainda a melhoria que a gente espera porque isso não depende só da formação do professor, mas depende da gestão da escola, do clima escolar e de outros indicadores que a gente tem conhecimento. E que o INEP através dos Boletins, ele agora também está dando esse olhar. Porque tem o INSE o indicador sócio econômico, o perfil docente, então o resultado não chega para a escola só como um número. Então a gente tenta levar também esse olhar qualitativo. Eu preciso entender por que do meu resultado? Por que os meus alunos não conseguem avançar nos níveis de proficiência da ANA? Se encontram ainda nos níveis elementares, a gente começa a fomentar essa reflexão, essa discussão. (INT_II)

Conforme relatado pela INT_II, o INEP divulga juntamente com os relatórios de aprendizagem dos alunos, os resultados dos Indicadores de Contexto. Cabe ressaltar a importância dos resultados das avaliações impulsionando a reflexão acerca dos outros aspectos que impactam diretamente a aprendizagem e o desempenho dos alunos. A ótica deve se ampliar e outras políticas devem ser desenvolvidas para que se criem as melhores condições facilitadoras no processo de ensino e aprendizagem: 
[...] Como é o clima escolar, a relação com a comunidade, com a família, a gestão... é participativa, democrática, como é o envolvimento do professor, a assiduidade? Então vários aspectos vão dar um diferencial nesse resultado. Esse ano a gente fez um videozinho também, com práticas exitosas. A gente está terminando de formatar e eu tenho a intenção, junto com a equipe de estar encaminhando uma cópia para o INEP. Porque ficou muito legal, a gente pegou 10 escolas, temos escolas com IDEB 6.6. O que essa escola tem de diferente? Quem faz a escola, falando das suas práticas exitosas. (INT_II)

Com relação à influência dos resultados da ANA e da Provinha Brasil na definição de novas estratégias de formação continuada de professores, como se verifica a seguir:

A gente tem alguns programas de formação, como já tivemos outros que já se extinguiram como o Gestar, o Pró-letramento o Pro-formação. A gente tem um núcleo dentro da Secretaria que é um núcleo de formação e tem vários cursos que são oferecidos na Plataforma Freire, a questão da própria parceria com a Universidade Federal. A Secretaria também ministra oficinas através de seus serviços, o Serviço de Ensino Fundamental, Serviço de Ensino Médio com base no Enem. A gente se articula e o diferencial que eu achei do QEdu, é que ele traz quais são as habilidades daquela escola, daqueles alunos que fizeram aquela avaliação, que eles ainda não dominam. De forma bem clara. Então isso começa a dar um perfil para essas formações. Do que os professores estão precisando? O que eles precisam trabalhar com esses alunos a nível de competências e habilidades. Essas propostas não só do INEP, mas de outras instituições, da sociedade como um todo, nesse movimento, está ajudando a Secretaria a ter mais segurança de fazer esse trabalho de formação, de intervenção diante dos resultados externos. (INT_II)

d) Integração dos resultados das avaliações

Foi ressaltada, também, a importância das avaliações de alfabetização para a melhoria dos resultados da ANEB e ANRESC, as demais avaliações que compõem o SAEB, aplicadas ao final do ensino fundamental, conforme relato de um dos interlocutores:

Pra mim a Provinha Brasil junto com a ANA elas consolidam o processo de avaliação no $5^{\circ}$ ano. Porque quem tá indo bem na ANA, domina as habilidades de leitura e o raciocínio ele vai bem depois na Prova Brasil e é isso que eu estou esperando agora em relação ao resultado da Prova Brasil do $5^{\circ}$ ano da rede municipal.

Com relação à possibilidade de integração entre os resultados da Provinha Brasil e da ANA, os interlocutores ressaltaram a importância disso, porém há dificuldade em se estabelecer essa relação. Conforme relatado pela grande maioria, não há conhecimento técnico para a realização desse tipo de análise. Verifica-se, como na fala do INT_V, tentativas ainda que iniciais de análise integrada dos dados, incorporando, inclusive, avaliações de aprendizagem aplicadas pelas próprias escolas:

A gente tem buscado fazer isso, a gente tá tentando. Mas isso ainda não é... não é tranquilo, não é seguro e também não é de forma institucional. A gente tá só fazendo alguns estudos, algumas análises, tentando estabelecer com um grupo de escolas, 
não só usando as duas avaliações especificamente, mas também a própria avaliação que a escola faz. A dificuldade é técnica. Já que são duas avaliações que tem características diferentes e como a gente não tem todo o domínio teórico de elaboração das provas, a gente tem dificuldade de trabalhar com os resultados fazendo uma comparação direta. Teria que estabelecer parâmetros diferenciados, talvez, uma abordagem talvez mais estatística que a gente precise, por isso que a gente tem também buscado trabalhar mais em conjunto com o INEP. (INT_V)

Eu acredito que a gente precisa pensar em uma devolução mais pratica da Provinha Brasil e da ANA e que elas conversassem mais. Dialogassem entre si. Porque queira ou não queira, uma vai influenciar na outra. Porque quando você faz a Provinha Brasil, você já tem um diagnóstico dos alunos do $2^{\circ}$ ano. Que serão os nossos alunos do $3^{\circ}$ ano, o público da aplicação da ANA. Então você já tem um diagnóstico de quais são essas habilidades que eles já dominam e quais que eles ainda não dominam. Eu acredito que dá pra você ter essa comparação e que dentro desse comparativo você trace um indicador. Eu até creditei que ia ser colocado um indicador de alfabetização, através dos resultados da ANA, como tem o IDEB. Eu achei que teria essa pretensão, porque seria interessante para os estados. A escola tem um indicador de nível de alfabetização, os estados, o município... Ainda não de forma estatística, com propriedade ainda não. A gente precisa de uma ajuda nesse sentido. (INT_IV)

A gente tem feito, mas ainda precisamos avançar. $\mathrm{O}$ que a gente tem feito é pegar por exemplo esse aluno do $2^{\circ}$ ano, na primeira etapa e na segunda etapa, como é que vai ser o resultado da primeira etapa de 2015, como é que vai ser o resultado da segunda etapa em 2015. Esse aluno esse ano ele está na $2^{a}$ fase ano que vem ele vai fazer a ANA. Então a gente procura acompanhar... mas compilar, ainda não. (INT_IV)

e) Diagnóstico de alfabetização

Foi unânime, entre os interlocutores, a contribuição dos resultados das avaliações para se estabelecer um diagnóstico da alfabetização, como declarado abaixo:

Contribui muito. Eu acho que foi uma das criações do INEP em termos da ajuda do desenvolvimento da educação, uma das mais importantes. A gente vê que o resultado da Prova Brasil, para o nosso estado, ele teve assim um índice muito aquém daquilo que poderia ser. Quando se avalia $5^{\circ}$ ano, $9^{\circ}$ ano, a identificação de muitos alunos que não conseguem fazer a interpretação, a leitura... Então a Provinha ela veio fortalecer, só que diante de tudo que vem acontecendo em termos de busca de acompanhamento da qualidade da educação, a gente observa que ainda precisa caminhar bastante aqui o Estado. A título tanto da utilização dos resultados, quanto da maior consciência em termos de apropriação dos resultados. A Provinha Brasil é diagnóstica e dá pra trabalhar por aluno, por turma. (INT_III)

Com certeza. Eu vejo que o PNAIC deveria se utilizar desse resultado porque eles te dão assim, um norte para que você mude a sua prática educativa, para que efetivamente... eu vejo assim, ensinar o aluno a ler e a escrever, interpretar, é uma questão de cidadania. Na capital eles fazem esse diagnóstico, fazem a análise e a partir dessa análise é tomada de decisão para a melhoria do processo de alfabetização. (INT_II)

Porém, é necessário ponderar os aspectos que estão facilitando ou dificultando a utilização desses resultados para uma leitura da realidade da alfabetização dos estados e municípios. Identificou-se como um dos fatores que dificultam essa análise, o timing da divulgação dos resultados da ANA. Enquanto a Provinha Brasil é diagnóstica e permite a 
aplicação, consolidação e utilização quase que imediata dos resultados, a ANA obedece a um processo mais complexo e demorado de divulgação:

O resultado (ANA e também Prova Brasil) só chega no ano seguinte, é sempre o planejamento futuro. Sempre planejamento futuro. A Provinha não, eu aplico e tenho o resultado de forma imediata. Trato as ações, porque tenho a provinha inicial e a final, trato as ações nesse período e vou fazer uma prestação no final do ano ( $3^{\circ}$ ano, autor). Então eu tenho como comparar o que avançou e o que não avançou porque eu consegui fazer intervenções durante o processo e não tem como fazer com a ANA e nem com a Prova Brasil. Mas com a avaliação da rede, um sistema de avaliação isso é possível. (INT_II)

f) Sistemas próprios de avaliação

Esse também foi um dos principais fatores levantados pelos interlocutores para a formalização, nos estados, de seus sistemas próprios de avaliação. Dos seis entrevistados, apenas uma unidade da Federação não tinha pretensão ou estava em vias de desenvolver seu próprio programa de avaliação. Outro fator levantado para a necessidade de se estabelecer seus próprios mecanismos de avaliação é a divulgação de resultados, no caso da ANA e de demais avaliações em larga escala aplicadas pelo Governo Federal, serem apenas por unidade escolar e não alcançarem, individualmente, o aluno. Para uma análise mais aprofundada dos resultados e identificação das habilidades que os alunos já dominam ou em que ainda precisam avançar, é necessário que os resultados sejam individualizados:

A gente já está com o projeto de lei para ser aprovado da aquisição do nosso sistema próprio. Já foi mandado para assembleia, já foi feita toda a aprovação do sistema estadual [...] Eu acredito que se a gente tiver o resultado mais rápido, mais efetivo, assim como a gente tem com a Provinha, eu acho que se o professor se apropriasse, se esse resultado saísse por aluno, que tivesse essa formação concomitante a esses resultados, eu acredito que a gente teria uma melhora nos nossos níveis, nas nossas proficiências. [...] mas esse olhar externo precisa continuar porque ele vai servir também de um termômetro para que a gente faça uma avaliação de como está nossa rede em relação ao Brasil, para que a gente também não fique restrito. Achando que está tudo bom, perfeito, acabado e só olhar para o nosso umbigo, para o nosso sistema. Eu não desqualifico, se a gente tiver um sistema próprio, não vai ser mais preciso fazer prova Brasil nem ANA? Pelo contrário, a gente precisa saber nós estamos, esse parâmetro em relação ao nosso estado e ao Brasil, isso precisa continuar. (INT_II)

Mais uma vez evidencia-se a importância das avaliações externas aplicadas pelo Governo Federal para os gestores das instâncias intermediárias das Secretarias de Educação. Foi unânime entre os entrevistados que, mesmo com a intenção em se adotar sistemas próprios de avaliação, consideram a relevância das avaliações nacionais de alfabetização como forma de balizar seus próprios sistemas e municiar suas redes de informações que devem ser traduzidas em ações em prol da melhoria da qualidade do ensino. 


\section{CONSIDERAÇÕES FINAIS}

A presente pesquisa procurou caracterizar e desvelar as funções das avaliações de alfabetização, bem como compreender de que forma as Secretarias Estaduais de Educação que não dispõem de sistemas próprios de avaliação da educação básica utilizam os resultados produzidos pela ANA e Provinha Brasil.

Os dados apurados demonstram que, se em parte o Brasil tem avançado na universalização da oferta de ensino em nível fundamental, a discussão premente e o grande desafio das políticas educacionais é garantir condições de permanência dos alunos nas escolas e, principalmente, garantir qualidade aos processos educacionais.

Muitos estudos foram desenvolvidos no decorrer de duas décadas de institucionalização do SAEB e os resultados das avaliações revelaram que há um longo caminho a percorrer para que os alunos brasileiros atinjam níveis de proficiência em português e matemática que demonstrem a aquisição das competências básicas de letramento e alfabetização.

Farias e Filgueiras (2003, p. 37) ponderam que, se o SAEB foi desenhado primordialmente para fornecer subsídios para a formulação de programas e para a avaliação das políticas, sendo, assim, mais uma ferramenta para o planejamento e o monitoramento do que um indutor da responsabilidade dos provedores locais e da participação de outros atores, nem nesse aspecto mais restrito os seus resultados e a sua utilização parecem estar promovendo mudanças expressivas, a despeito do que tem sido apregoado oficialmente.

Para responder às questões que deram origem a este estudo foram elencados objetivos específicos, os quais foram plenamente atingidos na pesquisa. O primeiro deles foi compreender o funcionamento da metodologia de aplicação e de apresentação dos resultados da ANA como novo instrumento de avaliação da alfabetização. A pesquisa contribuiu para o entendimento de que a ANA, como uma avaliação externa, porém transversal, já que é aplicada ao final do $3^{\circ}$ ano ensino fundamental, serve como uma linha de base acerca da alfabetização no Brasil e tem seus resultados apresentados em produtos que não caracterizam o processo de aprendizagem, porém representam um retrato da alfabetização dos alunos ao final daquela etapa de ensino. Por não se tratar de avaliação processual ou diagnóstica, não possibilita o acompanhamento imediato dos alunos conforme o faz a Provinha Brasil, com intervenção contígua e resultados individualizados. Todavia, os resultados da ANA trazem um componente importante para a compreensão dos dados, que são os indicadores de contexto 
produzidos a partir da análise dos fatores externos, os quais influenciam no processo de alfabetização.

O segundo objetivo específico era comparar as matrizes de referência e os níveis de proficiência da Provinha Brasil e da ANA. Nesse sentido, constatou-se que as matrizes de referência das avaliações foram construídas a partir de concepções diferentes e se propõe a avaliar construtos distintos. Os resultados das avaliações são demonstrados em escalas de proficiência díspares, enquanto a Provinha Brasil leva em conta o número de acertos dos alunos nos itens de cada teste para determinar o nível de proficiência, a ANA traz os seus resultados em uma escala de interpretação pedagógica construída a partir níveis progressivos que reúnem as habilidades adquiridas pelos alunos. Portanto, o estudo demonstrou técnica e metodologicamente a impossibilidade de integração ou comparação direta dos resultados de ambas as avaliações de alfabetização, tanto pelo modelo de matrizes de referência e escalas de proficiência em que são construídos os itens e divulgados os resultados, quanto pela periodicidade com que os resultados são disseminados.

Como terceiro objetivo específico a pesquisa propôs investigar de que forma os resultados da ANA e da Provinha Brasil são disseminados. Verificou-se que os resultados da Provinha Brasil são calculados pelos próprios professores ou redes de ensino, porém dependendo da metodologia empregada, identificam-se problemas quanto à sua fidedignidade e compreensão. Dessa forma, a apreensão e utilização dos resultados torna-se mais fácil para as redes que desenvolveram sistemas próprios de consolidação e divulgação dos resultados da Provinha Brasil. Os resultados da ANA são divulgados pelo Inep através de seu portal, estratificados por UF, Município e Escola e os gestores estaduais de educação podem acessar os resultados de suas escolas através de acesso ao sistema, além de os receberem por meio de planilhas eletrônicas. Foi possível identificar um avanço na forma de divulgação dos resultados da ANA de 2013 para 2014 com a criação do painel educacional que consolida os resultados em boletins completos, incluindo os indicadores de contexto. Porém, as escolas ainda enfrentam muita dificuldade no acesso e na compreensão dos dados divulgados o que exige um apoio das secretarias de educação.

O último objetivo específico foi examinar a percepção dos interlocutores estaduais acerca dos resultados da ANA e da Provinha Brasil. Conclui-se, a partir da percepção dos gestores, que a ANA combinada com a Provinha Brasil é capaz de compor um diagnóstico da alfabetização, pois as duas avaliações apesar de não terem seus resultados comparáveis, demonstram para professores, escolas e redes de ensino o caminho que está sendo trilhado em 
direção ao objetivo de ter todas as crianças de oito anos alfabetizadas. Porém, constatou-se que a agregação dos resultados da ANA em nível de escola é um de seus limitadores, pois pode mascarar características importantes do processo de aquisição e domínio de habilidades de cada um dos alunos. Nesse sentido, os resultados da Provinha Brasil permitem uma melhor apropriação por parte dos professores e possibilitam maior intervenção nas práticas pedagógicas, já que são apresentados individualmente, demonstrando a realidade de cada turma. Evidenciou-se, ainda, que a agregação e a demora na divulgação dos resultados das avaliações nacionais, incluindo a ANA, é um dos principais motivos para que as Secretarias Estaduais de Educação desenvolvam seus próprios sistemas de avaliação.

Adicionalmente, o estudo constatou que não há grande diferença nos níveis de proficiência alcançados pelos alunos nas aplicações da ANA nos anos de 2013 e 2014. Os dados demonstram que grande parte dos alunos brasileiros ainda se encontra em níveis elementares da alfabetização. Dessa forma, há a necessidade de se investir na formação dos profissionais alfabetizadores e é positivo que os interlocutores já consigam identificar avanços na prática docente, decorrentes da participação desses profissionais nos programas de formação do PNAIC. Porém é necessário que os resultados da formação docente e das práticas diferenciadas de ensino reflitam melhorias nos resultados das avaliações.

Demonstrou-se, ainda, que a ANA não pode ser caracterizada como um instrumento de gestão para o PNAIC e seus resultados é sempre para a tomada de ações futuras e não permitem efeitos diretos nas turmas avaliadas. Nessa perspectiva, o estudo suscita o questionamento acerca da necessidade de sua aplicação anual, considerando o formato complexo de avaliações em larga escala, com divulgação de resultados em momento muito posterior ao de aplicação. Fica clara a visão contrária entre os especialistas do Inep e os interlocutores das Secretarias Estaduais de Educação quanto à esse aspecto, tendo em vista que para os servidores do Inep, a ANA não precisaria ser anual, quiçá necessária, considerando-se que o SAEB é capaz de demonstrar os mesmos resultados. Já os gestores das Secretarias de Educação pesquisadas, consideram importante que a avaliação seja anual, pois não dispõem de outra fonte de informação, se não, as avaliações federais, ainda que estas não traduzam todas as questões necessárias para a implementação de ações de intervenção imediatas.

O Pacto prevê uma relação mais próxima entre a Provinha Brasil e a ANA e trouxe a possibilidade da criação de um indicador de alfabetização. A pesquisa mostra a expectativa pela criação desse índice de alfabetização, que assim como o IDEB, traduza em metas claras 
"onde estamos e onde queremos chegar". Esse indicador ainda não foi desenvolvido, mas deve ser pensado em conjunto com uma revisão das matrizes de referência e escalas de proficiência das avaliações da alfabetização para que estas comuniquem de que maneira as habilidades e competências descritas ali estão em consonância com os currículos e propostas pedagógicas empregadas nas escolas.

Reconhecendo-se a importância das avaliações externas para as políticas públicas em educação, alerta-se para a implantação de processos complexos e dispendiosos de aplicação das avaliações em larga escala que terminam por demonstrar mais do mesmo. Os dados do SAEB, já apontavam problemas graves na eficiência do ensino oferecido pelas escolas brasileiras, como o baixo desempenho em leitura demonstrado pelos alunos. Os dados da ANA, analisados ainda que de forma breve e preliminar, confirmaram o que o SAEB já vem mostrando em suas edições. Infere-se que a ANA pode oferecer o diagnóstico precoce dos problemas estruturais da alfabetização no Brasil, porém é premente que seus resultados cumpram a função de oferecer subsídios ao desenvolvimento de ações que contribuam para a melhoria da aprendizagem e a plena alfabetização das crianças ao final do ciclo.

Dessa forma, algumas linhas de investigação podem ser criadas a partir da presente pesquisa que aprofundariam as conclusões demonstradas até aqui, como a análise da percepção de escolas e professores acerca dos usos dos resultados das avaliações de alfabetização. Além disso, é importante que se trace um panorama mais contextualizado acerca dos resultados das avaliações e isso é possível combinando dados sobre a trajetória e o contexto dos alunos com os resultados de desempenho nas avaliações. Considerando a importância de se produzir um diálogo entre as avaliações aplicadas pelos entes subnacionais e as avaliações federais, é necessário conhecer de que maneira as ações do PNAIC desenvolvidas em cada Unidade da Federação estão produzindo impactos nos resultados das avaliações aplicadas. Sugere-se ainda, que estudos futuros possam utilizar dados longitudinais considerando uma faixa temporal maior para análise. 


\section{REFERÊNCIAS}

AFONSO, Almerindo Janela. Estado, políticas educacionais e obsessão avaliativa. Contrapontos, Florianópolis, v. 7, n. 1, abr. 2007. p. 11-22.

ARAUJO, Carlos Henrique, LUZIO, Nildo. Avaliação da Educação Básica em busca da qualidade e equidade no Brasil. Brasília, Instituto Nacional de Estudos e Pesquisas Educacionais, 2005.

BONAMINO, Alicia Maria Catalano; SOUSA, Sandra Zákia. Três gerações de avaliação da educação básica no Brasil: interfaces com o currículo da/na escola. Educação e Pesquisa. São Paulo, v. 38, n. 2, jun. 2012.

BRASIL, Constituição da República Federativa do Brasil. Brasília, Senado Federal, Coordenação de Edições Técnicas, 2013.

Educação brasileira: indicadores e desafios: documentos de consulta. Organizado pelo Fórum Nacional de Educação. Brasília, Ministério da Educação, Secretaria Executiva, Secretaria Executiva Adjunta, 2013b. 95 p.

Lei de Diretrizes e Bases da Educação Nacional: lei 9394/96, de 20 de dezembro

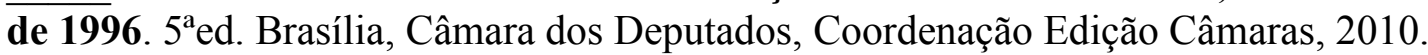

Decreto n $^{0} 6094$ de 24 de abril de 2007. Dispõe sobre a implementação do Plano de Metas Compromisso Todos pela Educação. Diário Oficial da União, Brasília, DF, 24 abr. 2007.

Lei no 10.172, de 9 de janeiro de 2001. Aprova o Plano Nacional de Educação - PNE e dá outras providências. Diário Oficial da União, Brasília, DF, 10 jan. 2001.

Lei no 13.005, de 25 de junho de 2014. Aprova o Plano Nacional de Educação - PNE e dá outras providências. Diário Oficial da União, Brasília, DF, 26 jun. 2014.

Instituto Nacional de Estudos e Pesquisas Educacionais Anísio Teixeira. Avaliação Nacional da Alfabetização: documento básico. Brasília, DF: INEP, 2013.

. Avaliações da educação básica em debate: ensino e matrizes curriculares de referência das avaliações em larga escala. - Brasília: Instituto Nacional de Estudos e Pesquisas Educacionais Anísio Teixeira, 2013. 467 p.

Avaliação Nacional da Alfabetização: relatório 2013-2014 : volume 1 : da concepção à realização. - Brasília, DF : Inep, 2015. 115 p.

Avaliação Nacional da Alfabetização: relatório 2013-2014 : volume 2 :

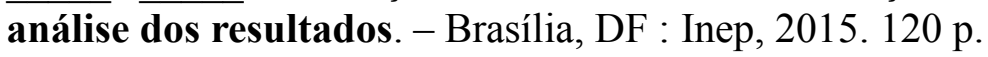

. Boletim escolar. 2015. Disponível em: <http://ana.inep.gov.br/ANA/>.

Brasília, DF: INEP, 2013.

Guia de correção e interpretação dos resultados Provinha Brasil: leitura. 
Brasília, DF: INEP, 2014.

Guia de correção e interpretação dos resultados Provinha Brasil: leitura.

Guia de Orientação para Elaboração de Itens - Provinha Brasil, Brasília,

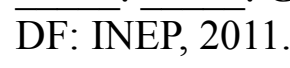

educacional $>$.

Painel Educacional. 2015. Disponível em: <http://portal.inep.gov.br/painel-

. Provinha Brasil: guia de elaboração de itens. Brasília, DF: INEP, 2013.

Ministério da Educação (MEC). Portaria no 931, de 21 de março de 2005. Institui o Sistema de Avaliação da Educação Básica, composto pela Prova Brasil (Anresc) e pelo Saeb (Aneb). Diário Oficial da União, Brasília, DF, 22 mar. 2005.

. Portaria no 10, de 24 de abril de 2007. Institui a Avaliação de Alfabetização "Provinha Brasil". Diário Oficial da União, Brasília, DF, 26 abr. 2007.

Portaria $n^{0}$ 867, de 4 de julho de 2012. Institui o Pacto Nacional pela Alfabetização na Idade Certa e as ações do Pacto e define suas diretrizes gerais. Diário Oficial da União, Brasília, DF, 5 jul. 2012. Seção 1, p. 22.

. Portaria $\mathbf{n}^{0}$ 482, de 7 de junho de 2013. Incorpora a Avaliação Nacional da Alfabetização ao SAEB. Diário Oficial da União, Brasília, DF, 10 jun. 2013.

BRESSER-PEREIRA, Luiz Carlos. Da Administração Pública Burocrática à Gerencial. Revista do Serviço Público. Brasília-DF, 47 (1), jan./abr. 1996.

Do Estado patrimonial ao gerencial. In: PINHEIRO, P. S. e outros. (Orgs.). Brasil: um século de transformações. São Paulo. Cia. Das Letras, 2001.

BROOKE, Nigel; CUNHA, Maria Amália A. A avaliação externa como instrumento da gestão educacional nos Estados. São Paulo: Fundação Victor Civita, 2011.

BROOKE, Nigel; CUNHA, Maria Amália A.; FALEIROS, Matheus. A avaliação externa como instrumento da gestão educacional dos estados. São Paulo: Game/FAE/UFMG, 2011.

CASTRO, M.H. A participação do Brasil em Estudos e Avaliações Comparados Internacionais. Disponível em: <http://www.mre.gov.br/dc/textos/revista7-mat21.pdf>, 2009.

. Sistemas de avaliação da educação no Brasil: avanços e novos desafios. São Paulo, v. 23, n. 1, p. 5-18, jan./jun. 2009

CHELI. Gabriela N. Plan jefas y jefes de hogar desocupados: un estudio de caso. Reflexões para Ibero-América: Avaliação de Programas Sociais / Cibele Franzese. [et al.]; Prefácio de Paulo Martino Jannuzzi. - Brasília: ENAP, 2009.

COSTA, F. L. Reforma do Estado e Contexto Brasileiro: crítica do paradigma 
gerencialista. Rio de Janeiro: FGV, 2010.

COTTA, T. Avaliação Educacional e políticas públicas: a experiência do sistema nacional de avaliação da educação básica (SAEB). Revista do Serviço Público. Ano 52 nº 4 Brasília 2001.

DALBEN, Ângela I. L. de F. Das avaliações exigidas às avaliações necessárias. Trabalho apresentado ao XI Endipe, maio/2002.

DAVOK, D. F. Qualidade em educação. Avaliação, v. 12, n. 3, p. 505-513, set. 2007.

DE PAUlA, Ana Paula Paes. Administração Pública Brasileira Entre o Gerencialismo e a Gestão Social. RAE. São Paulo, FGV, vol. 45, p. 36-49, jan./mar. 2005.

DENZIN, N.K.; LINCOLN, Y.S. Handbook of qualitative research. Thousand Oaks: Sage, 2005.

DERLIEN, Hans-Ulrich. Una comparación internacional en la evaluación de las políticas públicas. Revista do Serviço Público, Rio de Janeiro, v. 52, n. 1, p. 105-122, jan./mar. 2001.

DOURADO, L. F.; OliVEIRA, J. F. de; SANTOS, C. de A. A qualidade da educação: conceitos e definições. Brasília: MEC/INEP, 2007.

FARIA, Carlos Aurélio Pimenta de. A política da avaliação de políticas públicas. Revista Brasileira de Ciências Sociais, São Paulo, v. 20, n. 59, p. 97-109, out. 2005.

FARIA, Carlos Aurélio P.; FILGUEIRAS, Cristina de A. C. (2003). A avaliação de políticas públicas como instrumento de planejamento: os casos do Sistema de Avaliação da Educação Básica (Saeb), do Brasil, e do Sistema de Medición de la Calidad de la Educación (Simce), do Chile. Trabalho apresentado no GT "Políticas Públicas" do XXVII Encontro Anual da Anpocs. Caxambu, MG, 21 a 25 de outubro.

FERNANDES, R. Índice de desenvolvimento da educação básica (IDEB). Brasília, DF: MEC/INEP, 2007. (Textos para Discussão, 26).

FERNANDES, Reynaldo; GREMAUD, Amaury Patrick. Qualidade da educação: avaliação, indicadores e metas. In: VELOSO, Fernando et al. (Orgs.). Educação básica no Brasil: construindo o país do futuro. Rio de Janeiro: Elsevier, 2009. p. 213-238.

FERRER, G. Sistemas de evaluación de aprendijazes en America Latina: Balances y Desafios. Ed. PREAL Santiago Chile 2006.

FORTUNATI, José. Gestão da Educação Pública: Caminhos e desafios. Porto Alegre, Artmed, 2007.

FRANCO, C. O SAEB - Sistema de Avaliação da Educação Básica: potencialidades, problemas e desafios. In: Revista Brasileira de Educação. n.17 pg 127-133. 2001

FREITAS, Luiz Carlos. Avaliação Educacional - Caminhando pela contramão. 2.ed. Vozes, 2009. 
GATTI, Bernardete A. Implicações e perspectivas da pesquisa educacional no Brasil contemporâneo. Caderno de Pesquisa: FGV, Rio de Janeiro, 2001.

Avaliação Educacional no Brasil: pontuando uma história de ações. Avaliação educacional no Brasil. EccoS Rev. Cient., UNINOVE, São Paulo: (n. 1, v. 4): 17-41. 2002.

GIMENES, Nelson A. S; SILVA, Vandré G. da; MORICONI, Gabriela M.; LOUZANO, Paula; PRÍNCIPE, Lisandra M.; LEME, Luciana França. Uso da avaliação externa por equipes gestoras e profissionais docentes: um estudo em quatro redes de ensino público. São Paulo: FCC/SEP, 2013.

GOMES NETO, João Batista, ROSENBERG, Lia. Indicadores de Qualidade do Ensino e seu Papel no Sistema Nacional de Avaliação. Em Aberto, Brasília, 1995.

HORTA NETO, João Luiz. Avaliação externa: a utilização dos resultados do SAEB 2003 na gestão do sistema público de Ensino Fundamental no Distrito Federal. Dissertação (Mestrado) - Faculdade de Educação, Universidade de Brasília, Brasília, DF, 2006.

. As Avaliações Externas e seus efeitos sobre as Políticas Educacionais: Uma Análise Comparada entre a União e os Estados de Minas Gerais e São Paulo. Tese de Doutorado- Faculdade de Educação, Universidade de Brasília, Brasília, DF, 2013.

KLEIN, Ruben. Avaliação em Larga Escala: uma proposta inovadora. Em Aberto, Brasília, 1995.

LDB, Lei de Diretrizes e Bases da Educação Nacional: lei 9394/96, de 20 de dezembro de

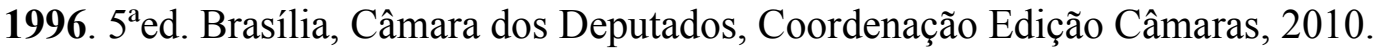

LUDKE, M.; ANDRÉ, M. E. D. A.- Pesquisa em educação: abordagens qualitativas. São Paulo, E.P.U., 1986.

BRASIL. Ministério da Educação. Como elaborar o Plano de Desenvolvimento da Escola. Brasília: MEC, 2006.

O Plano de Desenvolvimento da Educação: razões, princípios e programas. Brasília: MEC, 2011.

Pacto Nacional pela Alfabetização na Idade Certa: avaliação no ciclo de alfabetização - reflexões e sugestões. Brasília: MEC, 2012.

MELLO, Guiomar Namo de. Autonomia da escola: possibilidades, limites e condições. Estado e educação, Campinas: Papirus/Cedes; São Paulo: Ande/Anped, 1992, p.185-213. (Coletânea CBE).

MERRIAM, Sharan. Qualitative Research and Case Studies Applications in Education: Revised and Expanded from Case Study Research in Education. San Francisco: Jossey-Bass Publisher, 1998.

MORAIS, Artur Gomes de. Políticas de Avaliação da Alfabetização: discutindo a Provinha 
Brasil. Revista Brasileira de Educação, v. 17 n. 51 set.-dez. 2012.

MORAIS, Artur Gomes de; LEAL, Telma Ferraz; ALBUQUERQUE, Eliana Borges Correia. Provinha Brasil": monitoramento da aprendizagem e formulação de políticas educacionais. RBPAE - v.25, n.2, p. 301-320, mai./ago. 2012.

MORTATTI, Maria do Rosário Longo. Um balanço crítico da "Década da Alfabetização" no Brasil. Cad. CEDES [online]. 2013, vol.33, n.89, pp. 15-34.

MOURA, Raquel Souza Lima. Influências da Provinha Brasil de Matemática na Organização do Trabalho Pedagógico de um Grupo de Professoras de uma Escola Pública do Distrito Federal. Dissertação (Mestrado) - Faculdade de Educação, Universidade de Brasília, Brasília, DF, 2014.

OLIVEIRA, Ana Paula M. A Prova Brasil como política de regulação da rede pública do Distrito Federal. Dissertação (Mestrado) - Faculdade de Educação, Universidade de Brasília, Brasília, DF, 2011.

OLIVEIRA, João Batista Araújo e; SILVA, Luiz Carlos Faria da. Para que servem os testes de alfabetização?. Ensaio. Rio de Janeiro: Fundação Cesgranrio, v. 19, p. 827-840, 2011.

OLIVEIRA, Maria Auxiliadora Monteiro; ROCHA, Gladys. Avaliação em larga escala no Brasil nos primeiros anos do Ensino Fundamental. Disponivel em http://anpae.org.br/congressos_antigos/simposio2007/274.pdf.

PAES-SOUSA, R.; VAITSMAN, J. Síntese das pesquisas de avaliação de programas sociais do MDS. Cadernos de Estudos Desenvolvimento Social em Debate, n. 5, p. 1133.Brasília: Ministério do Desenvolvimento Social e Combate à Fome, Secretaria de Avaliação e Gestão da Informação, 2007.

- Avaliação de programas e transparência da gestão pública. Reflexões para IberoAmérica: Avaliação de Programas Sociais / Cibele Franzese. [et al.]; Prefácio de Paulo Martino Jannuzzi. - Brasília: ENAP, 2009.

PACHECO, Regina. Agenda da nova gestão pública. In: LOUREIRO, M. R.; ABRUCIO, F. L.; PACHECO, R. S. (Orgs.). Burocracia e Política no Brasil: desafios para a ordem democrática no séc. XXI. Rio de Janeiro: FGV, 2010.

PRESTES, Emilia Maria T. A avaliação de políticas sociais: questões teóricas,metodológicas e políticas. Revista Lusófona de Educação, v. 22, p. 85-102, 2012.

PIPOLO, Diana, MEDEIROS, Fátima Cristina. Provinha Brasil: uma metodologia em questão. In: Avaliar e intervir: novos rumos da avaliação educacional. Fortaleza: Imprece, 2010 .

QEDU. Resultado da Prova Brasil 2013 - Plataforma Qedu - www.qedu.org.br

RABELO, Edmar Henrique. Avaliação: novos tempos, novas práticas. Petrópolis, RJ: Vozes, 2001. 
RUS PEREZ, J.R. Por que pesquisar implementação de Políticas Educacionais atualmente? Educ. Soc., Campinas, v. 31, n. 113, p. 1179-1193, out.-dez. 2010. Disponível em http://www.cedes.unicamp.br

SASS, O.; MINHOTO, M. A. P. Indicadores e educação no Brasil: a avaliação como tecnologia. Revista de Teoria Crítica. v. 2, p. 232-252, 2011.

SILVA, Josiane Toledo Ferreira. Alfabetização, letramento e leitura: uma análise da matriz de referência para avaliação do PAEBES-Alfa.

SILVA, Maria Ozanira Silva. Construindo uma proposta metodológica participativa para desenvolvimento da pesquisa avaliativa: uma contribuição da teoria crítica para a prática do Serviço Social. Porto Alegre: Textos \& Contextos, 2012.

TRIVIÑOS, A. N. S. - Introdução à pesquisa em ciências sociais: a pesquisa qualitativa em educação. São Paulo, Atlas, 1987. 175p.

UNESCO. Documento Nacional preparatório a VI CONFINTEA. In Educação e aprendizagem para todos: olhares dos cinco continentes. Brasília: Unesco, 2009.

VIANNA, Heraldo Marelim. Avaliações em debate: SAEB, ENEM, PROVÃO. Brasília, Plano Editora, 2003.

Fundamentos de um programa de Avaliação Educacional. Brasília, Liber, 2005.

YIN, R.K. Case study research, design and methods (applied social research methods). Thousand Oaks. California: Sage Publications, 2009. 
APÊNDICES 


\section{Apêndice I \\ TERMO DE CONSENTIMENTO}

$\mathrm{Eu}$, , servidor da área de avaliação da

Secretaria Estadual de e interlocutor junto ao Instituto Nacional de Estudos e

Pesquisas Educacionais - INEP, concordo em participar da pesquisa intitulada "Os usos das Avaliações de Alfabetização nas políticas educacionais e possibilidades de construção de diagnóstico de alfabetização. Estou informado (a) de que a entrevista será realizada por telefone. Declaro estar ciente de que todas as informações coletadas nesta pesquisa serão divulgadas respeitando o anonimato do participante da pesquisa.

Assinatura 


\section{Apêndice II \\ ROTEIRO DO GRUPO FOCAL}

Público-alvo: cidadãos que fazem parte de instituições públicas que atuem com políticas públicas para educação. O grupo de pesquisa deverá ser composto por 10 participantes.

Objetivo da moderação: Investigar a percepção do grupo a respeito da implementação do Pacto Nacional de Alfabetização na Idade Certa e utilização da Avaliação Nacional da Alfabetização - ANA,

\section{Objetivos específicos:}

- Discutir o papel das avaliações em larga escala na gestão de políticas públicas educacionais.

- Conhecer o processo de concepção e implementação da ANA

- Analisar os primeiros resultados apresentados pela Avaliação Nacional de Alfabetização - ANA.

- Verificar possibilidade de diagnóstico da alfabetização a partir da análise comparada dos resultados da Provinha Brasil e da ANA.

\section{$\underline{\text { ROTEIRO }}$}

\begin{tabular}{|l|l|}
\hline \multirow{4}{*}{ Rapport (3 minutos) } & - Apresentação do moderador \\
\cline { 2 - 2 } & - Agradecer a presença \\
\cline { 2 - 2 } & - Falar sobre a pesquisa Focus Group \\
\cline { 2 - 2 } & - Não há certo nem errado \\
\cline { 2 - 2 } & - Explicar a função do gravador \\
\cline { 2 - 2 } Aquecimento: Apresentação do grupo (1'30 & - Falar da garantia de sigilo \\
\hline \multirow{2}{*}{ cada - total 15 minutos) } & - Nome \\
\cline { 2 - 2 } & - Lotação \\
\cline { 2 - 2 } & - Tempo de empresa \\
\cline { 2 - 2 } & - Rotina de trabalho \\
\hline
\end{tabular}




\section{INTRODUÇÃO AO TEMA}

Para iniciarmos, eu gostaria de saber que programas do governo ou políticas públicas para a educação básica. Vocês conhecem?

\section{DESENVOLVIMENTO}

1) Com o seu trabalho você contribui para a execução de alguma dessas políticas? Quais? E de que maneira?

2) Uma das iniciativas mais atuais em termos de políticas públicas para a educação é o Pacto Nacional de Alfabetização na Idade Certa. O que vocês conhecem sobre o Pacto?

3) Um dos eixos do Pacto é a Avaliação Nacional da Alfabetização - ANA. Qual a importância dessa avaliação para o desenvolvimento da política?

4) Na sua concepção, a ANA dialoga com outras avaliações? Quais? E como?

5) Os resultados da primeira aplicação da ANA nos permitem realizar que tipo de análise?

6) Quais os avanços entre a ANA 2013 e a ANA 2014?

\section{ENCERRAMENTO}

Vocês gostariam de falar mais alguma coisa para finalizar?

Gostaria de agradecer a presença e valiosa contribuição de todos para a realização da pesquisa proposta.

Obrigada. 


\section{Apêndice III \\ ROTEIRO DE ENTREVISTA SEMIESTRUTURADA}

Nome:

UF:

Formação:

Pós-graduação:

Cargo na Secretaria de Educação:

Tempo na Secretaria de Educação:

Tempo como interlocutor:

Funções como interlocutor:

Prezado (a) Interlocutor, a partir dos resultados da ANA e da Provinha Brasil,

1. Houve a Provinha Brasil em seu estado nos anos de 2013 e 2014?

2. Sua rede dispõe de Sistema próprio de coleta de dados da Provinha Brasil? Cite como é realizada a consolidação dos resultados da Provinha Brasil.

3. De que maneira a foram recebidos os resultados da ANA?

4. Como os resultados da ANA e da Provinha Brasil são apresentados à comunidade educacional e aos profissionais de cada escola?

5. Como os resultados da ANA e da Provinha Brasil influenciam a orientação da política educacional do estado? Cite exemplos de mudanças e novas práticas resultantes.

6. Os resultados da ANA e da Provinha Brasil ajudaram a definir novas estratégias de formação continuada dos professores? Cite exemplos/casos.

7. De que maneira o público, pais e sociedade, tem acesso aos resultados da ANA e da Provinha Brasil? Em caso de publicações e informações na rede de computadores, indicar o link.

8. Os resultados da ANA influenciam a destinação dos recursos orçamentários para as 
escolas? Descreva a forma como as avaliações contribuíram para a divisão desses recursos entre as escolas do seu estado.

9. O desempenho dos alunos nas avaliações interferiu na política de remuneração dos profissionais da educação, na forma de acréscimos salariais ou bonificações? Descreva a forma como as avaliações interferiram na política salarial dos professores, diretores e outros envolvidos.

10. Os resultados das avaliações foram utilizados para estabelecer os critérios da política de avaliação docente? De que maneira eles interferiram?

11. Os resultados das avaliações foram utilizados para classificação ou rankeamento de escolas da rede? Descreva a finalidade e como foi realizada essa classificação?

12. É realizada alguma análise comparada entre os resultados da ANA e da Provinha Brasil? Descreva de que maneira /estratégias de integração são realizadas.

13. Caso as avaliações não tenham sido utilizadas em nenhuma das situações acima descritas, identifique as outras formas pelas quais os resultados foram úteis.

14. Há pretensão do desenvolvimento de sistema próprio de avaliação? Cite razões para isso. 


\section{Apêndice IV \\ MATRIZES DE REFERÊNCIA}

\section{Matriz de Referência de Português da ANA}

\begin{tabular}{|c|c|}
\hline \multicolumn{2}{|c|}{$1^{\circ}$ EIXO Apropriação do Sistema de Escrita } \\
\hline \multirow{3}{*}{ D1 - Reconhecer letras } & D1.1 - Diferenciar letras de outros sinais gráficos. \\
\hline & D1.2 - Identificar as letras do alfabeto. \\
\hline & D1.3 - Identificar diferentes tipos de letras. \\
\hline D2 - Reconhecer sílabas. & $\begin{array}{l}\text { D2.1 - Identificar número de sílabas a partir de } \\
\text { imagens }\end{array}$ \\
\hline \multirow{5}{*}{$\begin{array}{l}\text { D3 - Estabelecer relação entre unidades sonoras e } \\
\text { suas representações gráficas }\end{array}$} & D3.1 - Identificar vogais nasalizadas. \\
\hline & $\begin{array}{l}\text { D3.2 - Identificar relação entre grafema e fonema } \\
\text { (letra/som - com correspondência sonora única; } \\
\text { ex.: p,b,t, d, f). }\end{array}$ \\
\hline & $\begin{array}{l}\text { D3.3 - Identificar relação entre grafema e fonema } \\
\text { (letra/som - com mais de uma correspondência } \\
\text { sonora; ex.: c e g). }\end{array}$ \\
\hline & $\begin{array}{l}\text { D3.4 - Reconhecer, a partir de palavra ouvida, o } \\
\text { valor sonoro de uma sílaba. }\end{array}$ \\
\hline & $\begin{array}{l}\text { D3.5 - Reconhecer, a partir de imagem, o valor } \\
\text { sonoro de uma sílaba. }\end{array}$ \\
\hline \multicolumn{2}{|c|}{$2^{\circ}$ EIXO Leitura } \\
\hline D4 - Ler palavras & $\begin{array}{l}\text { D4.1 - Estabelecer relação entre significante e } \\
\text { significado. }\end{array}$ \\
\hline D5 - Ler frases & D5.1 - Ler frases. \\
\hline D6 - Localizar informação explícita em textos. & D6.1 - Localizar informação explícita em textos. \\
\hline \multirow{3}{*}{ D7 - Reconhecer assunto de um texto } & $\begin{array}{l}\text { D7.1 - Reconhecer o assunto do texto com apoio } \\
\text { das características gráficas e do suporte. }\end{array}$ \\
\hline & $\begin{array}{l}\text { D7.2 - Reconhecer o assunto do texto com base } \\
\text { no título. }\end{array}$ \\
\hline & $\begin{array}{l}\text { D7.3 - Reconhecer o assunto do texto a partir da } \\
\text { leitura individual (sem apoio das características } \\
\text { gráficas ou do suporte). }\end{array}$ \\
\hline \multirow[t]{2}{*}{ D8 - Identificar a finalidade do texto } & $\begin{array}{l}\text { D8.1 - Reconhecer a finalidade do texto com } \\
\text { apoio das características gráficas do suporte ou do } \\
\text { gênero. }\end{array}$ \\
\hline & $\begin{array}{l}\text { D8.2 - Reconhecer a finalidade do texto a partir } \\
\text { da leitura individual (sem apoio das } \\
\text { características gráficas do suporte ou do gênero). }\end{array}$ \\
\hline D9 - Estabelecer relação entre partes do texto & $\begin{array}{l}\text { D9.1 - Identificar repetições e substituições que } \\
\text { contribuem para a coerência e coesão textual. }\end{array}$ \\
\hline D10 - Inferir informação & D10.1 - Inferir informação. \\
\hline \multicolumn{2}{|l|}{ Fonte: INEP/MEC } \\
\hline
\end{tabular}

Matriz de Referência de Matemática da Provinha Brasil

\section{$1^{\circ}$ Eixo Números e Operações}

D1 - Mobilizar ideias, conceitos e estruturas relacionadas à construção do significado dos números e suas representações
D1.1 - Associar a contagem de coleções de objetos à representação numérica das suas respectivas quantidades.

D1.2 - Associar a denominação do número à sua respectiva representação simbólica. D1.3 - Comparar ou ordenar quantidades pela 


\begin{tabular}{|c|c|}
\hline & $\begin{array}{l}\text { contagem para identificar igualdade ou } \\
\text { desigualdade numérica. }\end{array}$ \\
\hline & D1.4 - Comparar ou ordenar números naturais. \\
\hline $\begin{array}{l}\text { D2 - Resolver problemas por meio da adição ou } \\
\text { subtração }\end{array}$ & $\begin{array}{l}\text { D2.1 - Resolver problemas que demandam as } \\
\text { ações de juntar, separar, acrescentar e retirar } \\
\text { quantidades. }\end{array}$ \\
\hline & $\begin{array}{l}\text { D2.2 - Resolver problemas que demandam as } \\
\text { ações de comparar e completar quantidades. }\end{array}$ \\
\hline D3 - Resolver problemas por meio da aplicação & $\begin{array}{l}\text { D3.1 - Resolver problemas que envolvam as } \\
\text { ideias da multiplicação. }\end{array}$ \\
\hline divisão & $\begin{array}{l}\text { D3.2 - Resolver problemas que envolvam as } \\
\text { ideias da divisão. }\end{array}$ \\
\hline $2^{\circ}$ Eixo & eometria \\
\hline & D4.1 - Identificar figuras geométricas planas. \\
\hline geométricas & $\begin{array}{l}\text { D4.2 - Reconhecer as representações de figuras } \\
\text { geométricas espaciais. }\end{array}$ \\
\hline $3^{\circ}$ EIXO Grar & ezas e Medidas \\
\hline D5 - Identificar, comparar, relacionar e ordenar & D5.1 - Comparar e ordenar comprimentos. \\
\hline grandezas & D5.2 - Identificar e relacionar cédulas e moedas. \\
\hline & $\begin{array}{l}\text { D5.3 - Identificar, comparar, relacionar e ordenar } \\
\text { tempo em diferentes sistemas de medida. }\end{array}$ \\
\hline $4^{\circ}$ EIXO Tratam & to da Informação \\
\hline & $\begin{array}{l}\text { D6.1 - Identificar informações apresentadas em } \\
\text { tabelas. }\end{array}$ \\
\hline $\begin{array}{l}\text { D6 - Ler e interpretar dados em gráficos, tabelas } \\
\text { e textos }\end{array}$ & $\begin{array}{l}\text { D6.2 - Identificar informações apresentadas em } \\
\text { gráficos de colunas. }\end{array}$ \\
\hline
\end{tabular}

Matriz de Referência de Português da ANA

\begin{tabular}{|c|c|c|}
\hline Eixo Estruturante & Habilidades & Especificações das Habilidades \\
\hline \multirow{9}{*}{ LEITURA } & $\begin{array}{l}\text { H1. Ler palavras com estrutura silábica } \\
\text { canônica }\end{array}$ & $\mathrm{CV}$ \\
\hline & $\begin{array}{l}\text { H2. Ler palavras com } \\
\text { silábica não canônica }\end{array}$ & $\begin{array}{l}\mathrm{CCV}, \mathrm{CVC}, \mathrm{VC}, \mathrm{VC} ; \mathrm{VV}, \mathrm{CCVC} \text {, } \\
\text { entre outras. }\end{array}$ \\
\hline & H3. Reconhecer a finalidade do texto & \\
\hline & $\begin{array}{l}\text { H4. Localizar informações explícitas em } \\
\text { textos }\end{array}$ & $\begin{array}{l}\text { Cartazes, listas de telefone, guias } \\
\text { de programação infantil, } \\
\text { pequenos anúncios, reportagens } \\
\text { de jornais infantis, textos } \\
\text { informativos }\end{array}$ \\
\hline & $\begin{array}{l}\text { H5. Compreender os sentidos de palavras } \\
\text { e expressões em textos }\end{array}$ & $\begin{array}{llr}\begin{array}{l}\text { Textos } \\
\text { histórias, literários }\end{array} & \begin{array}{l}\text { (contos, } \\
\text { pequenas } \\
\text { pequenicas), }\end{array} \\
\end{array}$ \\
\hline & $\begin{array}{l}\text { H6. Realizar inferências a partir da } \\
\text { leitura de textos verbais }\end{array}$ & $\begin{array}{lcr}\text { Textos } & \text { literários } & \text { (contos, } \\
\text { histórias), artigos de } & \text { revista } \\
\text { infantil, } & \text { reportagens } & \text { de } \\
\text { suplementos infantis } & \end{array}$ \\
\hline & $\begin{array}{l}\text { H7. Realizar inferências a partir da } \\
\text { leitura de textos que articulem a } \\
\text { linguagem verbal e não verbal }\end{array}$ & $\begin{array}{l}\text { Pequenas tirinhas próximas do } \\
\text { universo infantil, quadrinhos de } \\
\text { uma página, primeira página de } \\
\text { jornais ou suplementos infantis, }\end{array}$ \\
\hline & $\mathrm{o}$ assunto de um texto & $\begin{array}{l}\text { Pequenas reportagens, textos } \\
\text { informativos }\end{array}$ \\
\hline & H9. Estabelecer relações entre partes de & Tempo, causa e consequência, \\
\hline
\end{tabular}




\begin{tabular}{|c|c|c|}
\hline & $\begin{array}{l}\text { um texto marcadas } \\
\text { coesivos }\end{array}$ & $\begin{array}{l}\text { finalidade Contos, histórias, } \\
\text { reportagens, textos informativos }\end{array}$ \\
\hline \multirow{3}{*}{ ESCRITA } & $\begin{array}{l}\text { H10. Grafar palavras com } \\
\text { correspondências regulares diretas }\end{array}$ & $\begin{array}{lr}\text { Grafar palavras } & \text { com } \\
\text { correspondências } & \text { regulares } \\
\text { diretas }(\mathrm{P}, \mathrm{B}, \mathrm{T}, \mathrm{D}, \mathrm{F}, \mathrm{V} \text { e M ou N } \\
\text { em início de sílaba) }\end{array}$ \\
\hline & $\begin{array}{lll}\text { H11. Grafar } & \text { palavras com } \\
\text { correspondencias regulares contextuais } \\
\text { entre letras } & \text { ou grupos de } \\
\text { letras e seu } & \text { valor sonoro }\end{array}$ & 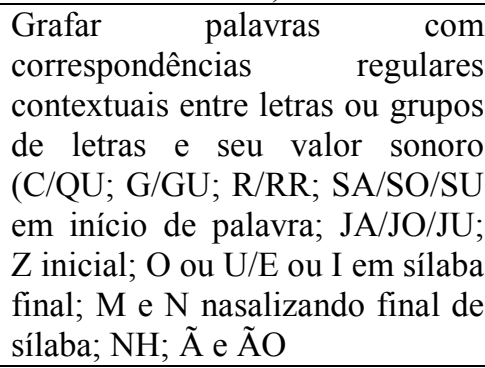 \\
\hline & $\begin{array}{l}\text { H12. Produzir um texto a partir de } \\
\text { uma situação dada }\end{array}$ & $\begin{array}{l}\text { Gerar o conteúdo textual de } \\
\text { acordo com o gênero solicitado. } \\
\text { Organizar o conteúdo textual, } \\
\text { estruturando os períodos e } \\
\text { utilizando recursos coesivos } \\
\text { (progressão do tempo, marcação } \\
\text { do espaço e relações de sentido). } \\
\text { Pontuar o texto. } \\
\text { Usar convencionalmente os } \\
\text { espaços entre palavras no texto. } \\
\text { Fazer uso da letra maiúscula nos } \\
\text { textos, segundo as convenções. } \\
\text { Grafar convencionalmente as } \\
\text { palavras do texto. }\end{array}$ \\
\hline
\end{tabular}

Matriz de Referência de Matemática da ANA

\begin{tabular}{|c|c|c|}
\hline Eixo Estruturante & Habilidades & Especificações das Habilidades \\
\hline \multirow{5}{*}{$\begin{array}{l}\text { NUMÉRICO E } \\
\text { ALGÉBRICO }\end{array}$} & \multirow[t]{2}{*}{$\begin{array}{l}\text { H1. Associar a contagem de coleções } \\
\text { de objetos à representação numérica } \\
\text { das suas respectivas quantidades }\end{array}$} & $\begin{array}{l}\text { Contar agrupamentos de até } 20 \\
\text { objetos dispostos: } \\
\text { de forma organizada; } \\
\text { de forma desorganizada; } \\
\text { agrupados de } 2 \text { em } 2 \text {, de } 3 \text { em } \\
3 \text {, de } 4 \text { em } \\
4 \text {, de } 5 \text { em } 5 \text { e } 10 \text { em } 10 \text {. }\end{array}$ \\
\hline & & $\begin{array}{l}\text { Contar agrupamentos de mais } \\
\text { de } 20 \text { objetos agrupados de } 2 \\
\text { em } 2 \text {, de } 3 \text { em } 3 \text {, de } 4 \text { em } 4 \text {, de } \\
5 \text { em } 5 \text { e } 10 \text { em } 10 \text { (com limite } \\
\text { numérico de 200). }\end{array}$ \\
\hline & $\begin{array}{l}\text { H2. Associar a denominação do } \\
\text { número à sua respectiva } \\
\text { representação simbólica }\end{array}$ & $\begin{array}{l}\text { Observação: } \\
\text { Apenas números de } 10 \text { a } 999 \\
\text { em algarismos indoarábicos, } \\
\text { ou em linguagem materna. }\end{array}$ \\
\hline & $\begin{array}{l}\text { H3. Comparar ou ordenar quantidades } \\
\text { pela contagem } \\
\text { para identificar igualdade ou } \\
\text { desigualdade numérica }\end{array}$ & $\begin{array}{l}\text { Comparar quantidades de: } \\
\text { objetos organizados; objetos } \\
\text { apresentados } \\
\text { desordenadamente. }\end{array}$ \\
\hline & $\begin{array}{l}\text { H4. Comparar ou ordenar números } \\
\text { naturais }\end{array}$ & $\begin{array}{l}\text { Escolher entre alternativas } \\
\text { apresentadas aquela que: } \\
\text { completa uma sequência de } \\
\text { quantidades crescentes. }\end{array}$ \\
\hline
\end{tabular}




\begin{tabular}{|c|c|c|}
\hline & & $\begin{array}{l}\text { completa uma sequência de } \\
\text { quantidades decrescentes. } \\
\text { corresponde a uma ordenação } \\
\text { crescente de quantidades. } \\
\text { Resolver problemas simples de } \\
\text { comparação numérica. } \\
\text { Observação: } \\
\text { 1. Representados ou não na } \\
\text { reta numérica. }\end{array}$ \\
\hline & H5. Compor e decompor números & $\begin{array}{l}\text { Observação } \\
\text { 1) Sistema de numeração } \\
\text { decimal até } 999 .\end{array}$ \\
\hline & $\begin{array}{l}\text { H6. Resolver problemas que } \\
\text { demandam as ações de juntar, separar, } \\
\text { acrescentar e retirar quantidades }\end{array}$ & $\begin{array}{l}\text { Operar com e sem } \\
\text { reagrupamentos. } \\
\text { Adicionar com até três parcelas. }\end{array}$ \\
\hline & $\begin{array}{l}\text { H7. Resolver problemas que } \\
\text { demandam as ações de comparar e } \\
\text { completar quantidades }\end{array}$ & 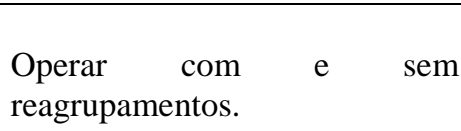 \\
\hline & H8. Cálculo de adições e subtrações & $\begin{array}{l}\text { Operar com e sem } \\
\text { reagrupamentos. } \\
\text { Adicionar com duas parcelas. }\end{array}$ \\
\hline & $\begin{array}{l}\text { H9. Resolver problemas que envolvam } \\
\text { as ideias da multiplicação }\end{array}$ & $\begin{array}{l}\text { Situações que envolvam adição } \\
\text { de parcelas iguais. } \\
\text { Situações que envolvam objetos } \\
\text { organizados em disposição } \\
\text { retangular. } \\
\text { Situações envolvendo a ideia de } \\
\text { proporcionalidade (dobro, triplo } \\
\text { etc). } \\
\text { Situações envolvendo a ideia de } \\
\text { combinação }\end{array}$ \\
\hline & $\begin{array}{l}\text { H10. Resolver problemas que } \\
\text { envolvam as ideias da } \\
\text { divisão }\end{array}$ & $\begin{array}{l}\text { Repartir uma coleção de objetos } \\
\text { em partes iguais. } \\
\text { Quantas vezes uma quantidade } \\
\text { cabe em outra. } \\
\text { Situações envolvendo a ideia de } \\
\text { proporcionalidade (metade, } \\
\text { terça e quarta parte). } \\
\text { Observação: } \\
\text { Considerar situações contínuas } \\
\text { e discretas. }\end{array}$ \\
\hline \multirow[t]{2}{*}{ GEOMETRIA } & $\begin{array}{l}\text { H11. Identificar figuras geométricas } \\
\text { planas }\end{array}$ & $\begin{array}{l}\text { Associar as seguintes figuras } \\
\text { planas com seus } \\
\text { respectivos nomes: triângulos, } \\
\text { quadrados, retângulos e círculos } \\
\text { em posição prototípica ou não. } \\
\text { Observação: } \\
\text { 1. Nos distratores podem ser } \\
\text { utilizadas quaisquer figuras } \\
\text { planas (ex. trapézio, pentágono } \\
\text { etc). } \\
\text { 2. Evitar usar quadrados, } \\
\text { retângulos e losangos num } \\
\text { mesmo item. }\end{array}$ \\
\hline & $\begin{array}{l}\text { H12. Reconhecer as representações de } \\
\text { figuras geométricas espaciais }\end{array}$ & $\begin{array}{l}\text { Associar representações de } \\
\text { objetos do mundo } \\
\text { físico a representações de }\end{array}$ \\
\hline
\end{tabular}




\begin{tabular}{|c|c|c|}
\hline & & 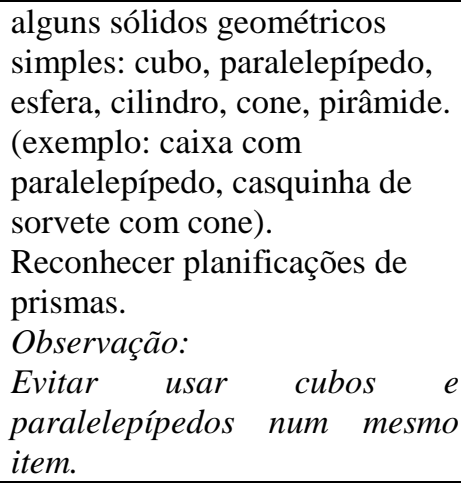 \\
\hline \multirow{4}{*}{$\begin{array}{l}\text { GRANDEZAS E } \\
\text { MEDIDAS }\end{array}$} & $\begin{array}{l}\text { H13. Comparar e ordenar } \\
\text { comprimentos }\end{array}$ & $\begin{array}{l}\text { Situações envolvendo desenhos } \\
\text { de objetos ou } \\
\text { personagens para estabelecer } \\
\text { comparativamente: o maior, o } \\
\text { menor, igual, o mais alto, o } \\
\text { mais baixo, o mais comprido o } \\
\text { mais curto, o mais grosso, o } \\
\text { mais fino, o mais estreito, o } \\
\text { mais largo. }\end{array}$ \\
\hline & $\begin{array}{l}\text { H14. Identificar e relacionar cédulas e } \\
\text { moedas }\end{array}$ & $\begin{array}{l}\text { Identificar cédulas e moeda do } \\
\text { sistema monetário brasileiro. } \\
\text { Identificar trocas e diferentes } \\
\text { formas para representar um } \\
\text { mesmo valor. } \\
\text { Dada uma cédula ou moeda, } \\
\text { reconhecer agrupamentos de } \\
\text { outras cédulas ou moedas, de } \\
\text { valores iguais, correspondentes } \\
\text { ao mesmo valor. } \\
\text { Dado um valor qualquer } \\
\text { representado por cédulas } \\
\text { e ou moedas, identificar outra } \\
\text { forma de obter o mesmo valor. }\end{array}$ \\
\hline & $\begin{array}{l}\text { H15. Identificar, comparar, relacionar e } \\
\text { ordenar tempo em diferentes sistemas } \\
\text { de medida }\end{array}$ & $\begin{array}{l}\text { Situações envolvendo } \\
\text { intervalos de tempo, diferentes } \\
\text { medidas de tempo (hora, dia, } \\
\text { semana, mês, ano, semestre, } \\
\text { bimestre); diferentes } \\
\text { instrumentos de medida de } \\
\text { tempo (relógios analógicos e } \\
\text { digitais, calendário). } \\
\text { Apresentar situações de rotina } \\
\text { escolar e de vida comparando } \\
\text { com os períodos do dia, do mês } \\
\text { e do ano; } \\
\text { Reconhecer horas cheias e } \\
\text { intervalos de cinco minutos em } \\
\text { relógio digital e em relógio } \\
\text { analógico; } \\
\text { Relacionar horários } \\
\text { apresentados em relógios digital } \\
\text { e analógico; } \\
\text { Identificar instrumentos de } \\
\text { medida de tempo; }\end{array}$ \\
\hline & H16. Ler resultados de medições & $\begin{array}{l}\text { Grandezas de comprimento, } \\
\text { massa, capacidade, } \\
\text { temperatura. } \\
\text { Observação: }\end{array}$ \\
\hline
\end{tabular}




\begin{tabular}{|c|c|c|}
\hline & & $\begin{array}{l}\text { Considerar apenas medidas } \\
\text { expressas por números } \\
\text { naturais. }\end{array}$ \\
\hline \multirow{2}{*}{$\begin{array}{l}\text { TRATAMENTO DA } \\
\text { INFORMAÇÃO }\end{array}$} & $\begin{array}{l}\text { H17. Identificar informações } \\
\text { apresentadas em tabelas }\end{array}$ & $\begin{array}{l}\text { Identificar informação em listas } \\
\text { ou tabelas de uma entrada, com } \\
\text { mais do que duas categorias. } \\
\text { Identificar informação que } \\
\text { exijam dois níveis de } \\
\text { localização, como tabelas de } \\
\text { dupla entrada. }\end{array}$ \\
\hline & $\begin{array}{l}\text { H18. Identificar informações } \\
\text { apresentadas em gráficos }\end{array}$ & $\begin{array}{l}\text { Reconhecer no gráfico (barras, } \\
\text { coluna ou pictórico) qual a } \\
\text { maior/menor frequência. } \\
\text { Dada uma frequência, localizar } \\
\text { a informação correspondente no } \\
\text { gráfico e vice-versa. }\end{array}$ \\
\hline
\end{tabular}




\section{Apêndice V \\ ESCALAS DE PROFICIÊNCIA DA ANA}

\section{LEITURA}

\begin{tabular}{|c|c|}
\hline Nível 1: Até 425 pontos & $\begin{array}{l}\text { Ler palavras dissílabas, trissílabas e polissílabas com estruturas } \\
\text { silábicas canônicas, com base em imagem. Ler palavras dissílabas, } \\
\text { trissílabas e polissílabas com estruturas silábicas não canônicas, com } \\
\text { base em imagem. }\end{array}$ \\
\hline Nível 2: Maior que 425 até 525 pontos & $\begin{array}{l}\text { Identificar a finalidade de textos como convite, cartaz, texto } \\
\text { instrucional (receita) e bilhete. } \\
\text { Localizar informação explícita em textos curtos (com até cinco } \\
\text { linhas) em gêneros como piada, parlenda, poema, tirinha (história em } \\
\text { quadrinhos em até três quadros), texto informativo e texto narrativo. } \\
\text { Identificar o assunto de textos, cujo assunto pode ser identificado no } \\
\text { título ou na primeira linha em gêneros como poema e texto } \\
\text { informativo. } \\
\text { Inferir o assunto de um cartaz apresentado em sua forma estável, } \\
\text { com letras grandes e mensagem curta e articulação da linguagem } \\
\text { verbal e não verbal. }\end{array}$ \\
\hline Nível 3: Maior que 525 até 625 pontos & 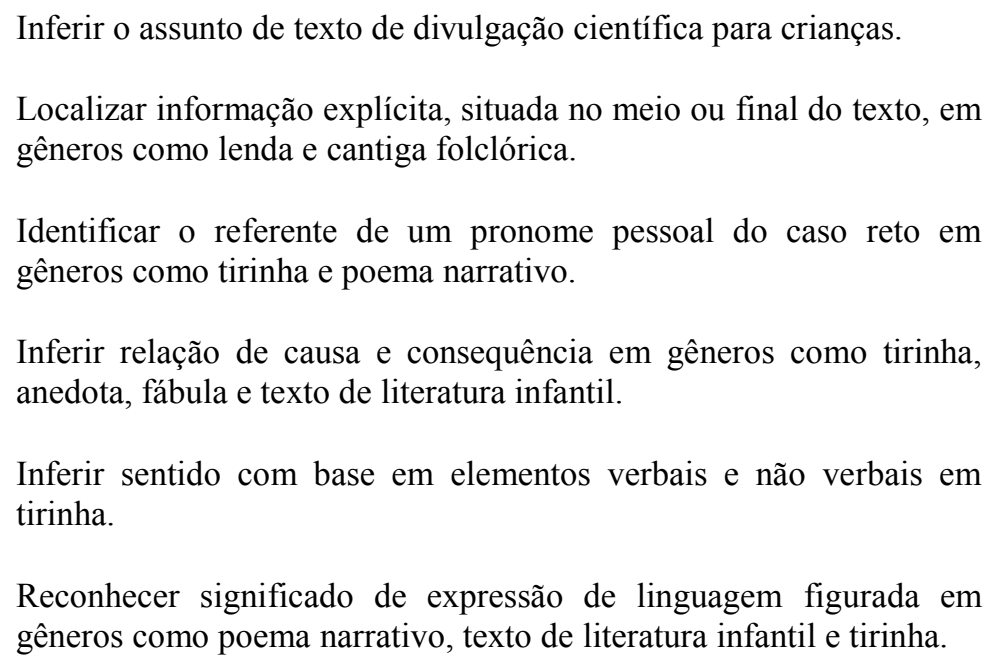 \\
\hline Nível 4: Maior que 625 pontos & $\begin{array}{l}\text { Inferir sentido de palavra em texto verbal. } \\
\text { Reconhecer os participantes de um diálogo em uma entrevista } \\
\text { ficcional. Inferir sentido em texto verbal. } \\
\text { Reconhecer relação de tempo em texto verbal. } \\
\text { Identificar o referente de pronome possessivo em poema. }\end{array}$ \\
\hline
\end{tabular}


MATEMÁTICA

\begin{tabular}{|c|c|}
\hline Nível 1: Até 425 pontos & $\begin{array}{l}\text { Reconhecer representação de figura geométrica plana } \\
\text { ou espacial em objetos de uso cotidiano; maior } \\
\text { frequência em gráfico de colunas; planificação de } \\
\text { figura geométrica espacial (paralelepípedo); horas e } \\
\text { minutos em relógio digital. } \\
\text { Associar objeto de uso cotidiano à representação de } \\
\text { figura geométrica espacial. } \\
\text { Contar objetos dispostos em forma organizada ou não. } \\
\text { Comparar medidas de comprimento em objetos do } \\
\text { cotidiano. }\end{array}$ \\
\hline Nível 2: Maior que 425 até 525 pontos & $\begin{array}{l}\text { Reconhecer nomenclatura de figura geométrica plana; } \\
\text { valor monetário de cédula; figura geométrica plana em } \\
\text { uma composição com várias outras. } \\
\text { Associar a escrita por extenso de números naturais } \\
\text { com até três algarismos à sua representação simbólica; } \\
\text { valor monetário de uma cédula a um agrupamento de } \\
\text { moedas e cédulas; } \\
\text { Completar sequência numérica crescente de números } \\
\text { naturais não consecutivos. } \\
\text { Comparar números naturais com até três algarismos } \\
\text { não ordenados. } \\
\text { Estimar uma medida entre dois números naturais com } \\
\text { dois algarismos. } \\
\text { Resolver problema de adição sem reagrupamento. }\end{array}$ \\
\hline Nível 3: Maior que 525 até 625 pontos & $\begin{array}{l}\text { Reconhecer frequências iguais em gráfico de colunas; } \\
\text { composição de números naturais com até três } \\
\text { algarismos, apresentada por extenso. } \\
\text { Completar sequência numérica decrescente de } \\
\text { números naturais não consecutivos. } \\
\text { Calcular adição de duas parcelas com reagrupamento. } \\
\text { Associar valor monetário de um conjunto de moedas } \\
\text { ao valor de uma cédula; a representação simbólica de } \\
\text { números naturais com até três algarismos à sua escrita } \\
\text { por extenso. } \\
\text { Resolver problema de subtração, com números } \\
\text { naturais de até dois algarismos, com ideia de comparar }\end{array}$ \\
\hline
\end{tabular}




\begin{tabular}{|l|l|}
\hline Nível 4: Maior que 625 pontos & e retirar e problema de divisão com ideia de repartir. \\
\hline Reconhecer composição e decomposição aditiva de \\
números naturais com até três algarismos; medidas de \\
tempo em relógios analógicos; informações em \\
gráfico de barras. \\
Calcular subtração de números naturais com até três \\
algarismos com reagrupamento. \\
Associar medidas de tempo entre relógio analógico e \\
digital. \\
$\begin{array}{l}\text { Resolver problema de subtração como operação } \\
\text { inversa da adição com números naturais; problemas } \\
\text { com a ideia de comparar números naturais de até três } \\
\text { algarismos; problema de multiplicação com a ideia de } \\
\text { proporcionalidade; problema de multiplicação com a } \\
\text { ideia de combinação; problema de divisão com ideia } \\
\text { de proporcionalidade e problema que envolve medidas } \\
\text { de tempo (dias de semanas). }\end{array}$
\end{tabular}

ESCRITA

\begin{tabular}{|c|c|}
\hline Nível 1: Até 400 pontos & $\begin{array}{l}\text { Neste nível, foram agrupados desde os alunos que, em } \\
\text { geral, são capazes de: } \\
\text { - Escrever palavras com sílabas canônicas (consoante } \\
\text { e vogal) e não canônicas, com alguma dificuldade, } \\
\text { pela omissão e/ou troca de letras; } \\
\text { Até os que são capazes de: } \\
\text { - Escrever ortograficamente palavras marcadas pela } \\
\text { presença de sílabas canônicas. }\end{array}$ \\
\hline Nível 2: Maior que 400 até 500 pontos & $\begin{array}{l}\text { Escrever ortograficamente palavras com sílabas não } \\
\text { canônicas; } \\
\text { Escrever textos incipientes apresentados na forma de } \\
\text { apenas uma frase; } \\
\text { Produzir textos narrativos, a partir de uma dada } \\
\text { situação, que apresentam ausência ou inadequação dos } \\
\text { elementos formais (segmentação, pontuação, } \\
\text { ortografia, concordância verbal e concordância } \\
\text { nominal) e da textualidade (coesão e coerência), } \\
\text { evidenciando ainda um distanciamento da norma } \\
\text { padrão da língua. }\end{array}$ \\
\hline Nível 3:Maior que 500 até 580 pontos & $\begin{array}{l}\text { Escrever textos narrativos com mais de uma frase, a } \\
\text { partir de uma situação dada; } \\
\text { Produzir textos narrativos com poucas inadequações }\end{array}$ \\
\hline
\end{tabular}




\begin{tabular}{|l|l|}
\hline & $\begin{array}{l}\text { relativas à segmentação, concordância verbal e } \\
\text { concordância nominal, embora com algum } \\
\text { comprometimento dos elementos formais e da } \\
\text { textualidade, evidenciando uma aproximação à norma } \\
\text { padrão da língua. }\end{array}$ \\
\hline Nível 4: Maior que 580 pontos & $\begin{array}{l}\text { Produzir textos narrativos, a partir de uma situação } \\
\text { dada, atendendo adequadamente ao uso de elementos } \\
\text { da textualidade, evidenciando o atendimento à norma } \\
\text { padrão da língua. }\end{array}$ \\
\hline
\end{tabular}

